\title{
Intensive Cultural Resources Survey of the Proposed Dripping Springs Wastewater System Improvements Project (EID 1), Dripping Springs, Hays County, Texas
}

Jahleen E. Sefton

Jeffrey D. Owens

Jesse O. Dalton

Follow this and additional works at: https://scholarworks.sfasu.edu/ita

Part of the American Material Culture Commons, Archaeological Anthropology Commons, Environmental Studies Commons, Other American Studies Commons, Other Arts and Humanities Commons, Other History of Art, Architecture, and Archaeology Commons, and the United States History Commons

Tell us how this article helped you.

This Article is brought to you for free and open access by the Center for Regional Heritage Research at SFA ScholarWorks. It has been accepted for inclusion in Index of Texas Archaeology: Open Access Gray Literature from the Lone Star State by an authorized editor of SFA ScholarWorks. For more information, please contact cdsscholarworks@sfasu.edu. 


\section{Intensive Cultural Resources Survey of the Proposed Dripping Springs \\ Wastewater System Improvements Project (EID 1), Dripping Springs, Hays County, Texas}

Creative Commons License

(c) $(1)$ ( 8

This work is licensed under a Creative Commons Attribution-NonCommercial 4.0 International License 


\section{Intensive Cultural Resources Survey of the Proposed Dripping Springs Wastewater System Improvements Project (EID 1), Dripping Springs, Hays County, Texas}

By:

Jahleen E. Sefton, Jeffrey D. Owens, and Jesse O. Dalton

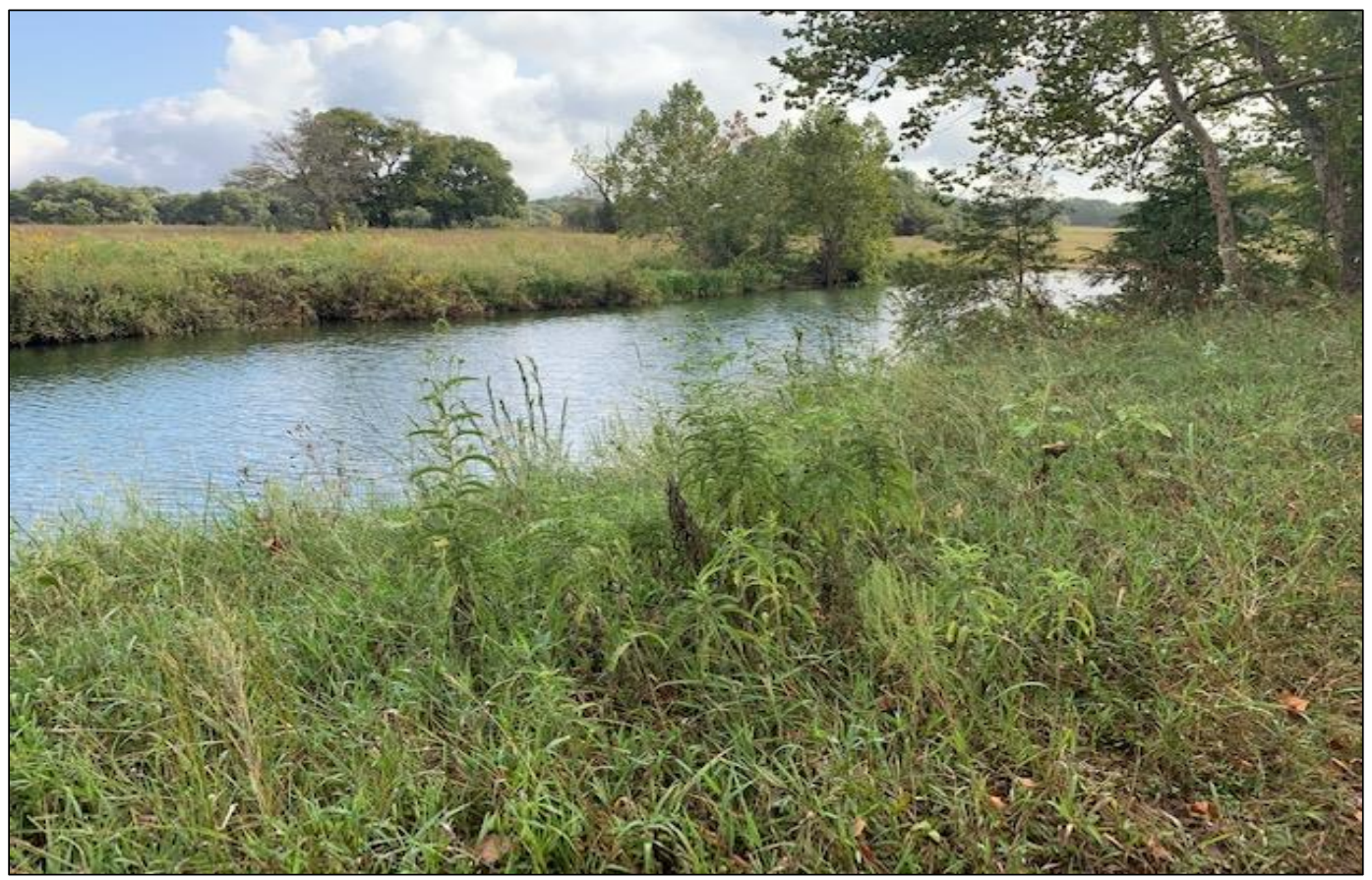

Texas Antiquities Permit No. 9114

USACE Project No. SWF-2020-00075

H414-190043

Prepared for:

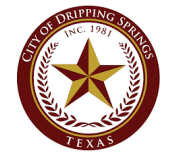

City of Dripping Springs

Dripping Springs, Texas
Prepared by:

\section{Horizon.}

Horizon Environmental Services, Inc. Austin, Texas

March 2020 



\section{Intensive Cultural Resources Survey of the Proposed Dripping Springs Wastewater System Improvements Project (EID 1), Dripping Springs, Hays County, Texas}

By:

Jahleen E. Sefton, Jeffrey D. Owens, and Jesse O. Dalton

Prepared for:

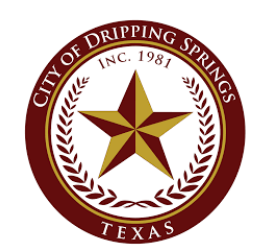

City of Dripping Springs

511 Mercer Street

Dripping Springs, Texas 78620

Prepared by:

\section{Horizon. \\ Environmental Services, Inc.}

Horizon Environmental Services, Inc.

$1507 \mathrm{~S}$. Interstate 35

Austin, Texas 78741

Jeffrey D. Owens, Principal Investigator H414-190043

USACE Project No. SWF-2020-00075

Texas Antiquities Permit No. 9114 



\section{MANAGEMENT SUMMARY}

Horizon Environmental Services, Inc. (Horizon) was selected by the City of Dripping Springs to conduct an intensive cultural resources inventory survey and assessment of the proposed Dripping Springs Wastewater System Improvements Project (EID 1) in Dripping Springs, Hays County, Texas (USACE Project No. SWF-2020-00075). This survey represents the first phase of a larger project involving the proposed construction of wastewater system improvements in Dripping Springs. The current phase of the project would involve three separate components-the West Interceptor segment, which extends approximately 3.7 kilometers (2.3 miles) in length along Onion Creek west of Farm-to-Market Road (FM) 12; the Reclaimed Water Line segment, which extends approximately 1.3 kilometers $(0.8$ mile $)$ in length between Needham Road and the intersection of FM 12 and FM 150; an approximately 2.3-hectare (5.7acre) effluent pond located south of an existing water reclamation facility south of FM 150; and the proposed expansion of the existing water reclamation facility adjacent to the proposed effluent pond, which together cover 3.3 hectares (8.0 acres). The linear rights-of-way (ROW) of proposed pipeline segments would measure a maximum of 30.5 meters (100.0 feet) in width, and the proposed project components would cover a combined area of approximately 18.5 hectares (45.6 acres).

The proposed undertaking would be sponsored by the City of Dripping Springs, a public subdivision of the state of Texas. As a political subdivision of the state of Texas, the project would fall under the jurisdiction of the Antiquities Code of Texas (Natural Resources Code, Title 9, Chapter 191). In addition, the project would utilize funding provided by the Clean Water State Revolving Fund (CWSRF) program, which is a federal-state partnership between the US Environmental Protection Agency (US EPA) and the state of Texas. As the US EPA is a federal agency, the project would also fall under the jurisdiction of Section 106 of the National Historic Preservation Act (NHPA) of 1966, as amended. As the proposed project represents a publicly sponsored undertaking, the project sponsor is required to provide the Texas Historical Commission (THC), which serves as the State Historic Preservation Office (SHPO) for the state of Texas, with an opportunity to review and comment on the project's potential to adversely affect historic properties listed on or considered eligible for listing on the National Register of Historic Places (NRHP) under the NHPA and for designation as State Antiquities Landmarks (SAL) under the Antiquities Code of Texas. 
From October 1 to 3, on November 4, and on November 22, 2019, Horizon archeologists Jesse Dalton, McKinzie Froese, Amy Goldstein, Elizabeth Sefton, and Jared Wiersema conducted an intensive cultural resources survey of the project area, including pedestrian walkover with shovel testing and backhoe trenching. The survey was performed under the supervision of Jeffrey D. Owens, who served as Principal Investigator, under Texas Antiquities Permit No. 9114. The purpose of the survey was to locate any significant cultural resources that potentially would be impacted by the proposed undertaking. Horizon's archeologists traversed the project area on foot and thoroughly inspected the modern ground surface for aboriginal and historic-age cultural resources.

Overall, vegetation across the entire project area generally consisted of short- to mediumlength grasses interspersed with mature live oak and cedar trees, which afforded fair to good ground surface visibility (30 to 60\%). Within the riparian zone of Onion Creek, vegetation consisted of tall, dense grass and mature honey mesquite, cedar, live oak, and hackberry trees, which provided poor ground surface visibility $(<30 \%)$.

The West Interceptor segment runs along the gravelly terraces of Onion Creek. Topographically, this segment of the project area consists of steep limestone steps and rocky outcrops that give way to flat, open fields. The proposed interceptor crosses Onion Creek at three locations, and the lower stream terraces of the creek have extensive gravel bars and debris associated with high-energy flooding. Soil profiles typically consist of a shallow A horizon of hard, calcareous clay loam underlain by dense gravelly deposits; however, in the southeastern portion of the West Interceptor, deeper clayey loam alluvium underlain by limestone bedrock was encountered.

The Reclaimed Water Line segment traverses the west-facing hillslopes of upland ridges east of Onion Creek. Approximately the southeastern half of this segment of the project area would be constructed within the existing ROW of FM 12 west of the roadway, and construction, use, and ongoing maintenance of the roadway and associated facilities has resulted in extensive prior disturbances. Evidence of ground disturbance resulting from land clearing for housing developments and a transmission line were also noted within the northwestern portion of the proposed Reclaimed Water Line segment. The far northwestern end of the proposed Reclaimed Water Line segment skims the edge of the floodplain associated with a tributary of Onion Creek. Sediments on the terraces of this stream channel consist of calcareous loamy alluvial deposits, while soils across the upland portions of the segment consist of shallow deposits of gravelly clay and clay loam underlain by naturally degrading limestone bedrock.

The water reclamation facility expansion and effluent pond segment are located on the upper terraces northeast of Onion Creek. The water reclamation facility is an existing industrial facility surrounded by septic fields, and prior disturbances from construction, use, and ongoing maintenance of the facility are extensive. The proposed expansion area to the north of the existing facility is currently utilized as a septic field. Sediments within this segment of the project area consist of shallow, gravelly, calcareous loamy to clayey loam alluvium underlain by naturally degrading limestone bedrock. 
Intensive Cultural Resources Survey of Proposed Dripping Springs

Wastewater System Improvements Project (EID 1), Dripping Springs, Hays County, Texas

In addition to a pedestrian walkover, the Texas State Minimum Archeological Survey Standards (TSMASS) require a minimum of 16 subsurface shovel tests per 1.6 kilometers (1.0 mile) for each 30.5-meter- (100.0-foot-) wide transect (or fraction thereof) for linear surveys unless field conditions warrant more shovel tests (e.g., in cultural high-probability areas) or fewer shovel tests (e.g., on steep slopes, in areas with excellent ground surface visibility). For blockarea surveys, the TSMASS require two shovel tests per 0.4 hectare $(1.0$ acre) for project areas between 1.2 and 4.0 hectares (3.0 and 10.0 acres) in size. As such, a minimum of 37 shovel tests would be required within the West Interceptor segment, 13 shovel tests would be required within the Reclaimed Water Line segment, and 16 shovel tests would be required within the proposed water reclamation facility expansion and effluent pond area, for a total of 66 shovel tests for the project area as a whole. Horizon excavated a total of 106 shovel tests during the survey, including 82 shovel tests within the West Interceptor segment, 13 shovel tests within the Reclaimed Water Line segment, and 11 shovel tests within the facility expansion and effluent pond area. The shovel tests within the proposed facility expansion and effluent pond area were not all excavated directly within the final proposed construction footprint as the boundaries of this portion of the project area had not been firmly determined at the time of the survey, and no shovel tests were excavated within the existing water reclamation facility due to the extent of observable prior disturbances within this area. Overall, Horizon exceeded the minimum number of shovel tests required for the project area as a whole, and it is Horizon's opinion that shovel testing was capable of fully penetrating sediments with the potential to contain subsurface archeological deposits (with the exception noted below where backhoe trenches were excavated along a portion of the West Interceptor segment).

In addition to shovel testing, Horizon excavated four backhoe trenches within the southeastern portion of the proposed West Interceptor segment. The trenches were excavated at roughly 100.0-meter (328.0-foot) intervals along the proposed centerline to depths ranging from 105.0 to 350.0 centimeters ( 41.3 to 137.8 inches) below surface. Sediments observed within trench profiles typically consisted of moderately deep deposits of grayish-brown fine clay loam over yellowish-brown fine sandy loam. Dense deposits of river cobbles and/or naturally degrading limestone bedrock were observed at the base of three of the four trenches, and it is Horizon's opinion that backhoe trenching was capable of fully penetrating sediments with the potential to contain archeological deposits.

One chert flake was recorded in a shovel test (ST AG30) at a depth of 0.0 to 30.0 centimeters ( 0.0 to 11.8 inches) below surface at the far northwestern end of the West Interceptor project segment. Supplemental delineation shovel tests excavated around this initial discovery failed to produce any additional evidence of prehistoric cultural activity at this location, so the chert flake was recorded as an isolated artifact occurrence but was not documented as an archeological site. No other cultural resources of prehistoric or historic age were recorded within the project area during the pedestrian survey, shovel testing, or backhoe trenching.

Based on the results of the survey-level investigations documented in this report, no cultural resources would be affected by the proposed undertaking. In accordance with 36 CFR 800.4, Horizon has made a reasonable and good-faith effort to identify historic properties within the project area. No cultural resources were identified within the project area that meet the criteria 
for designation as SALs according to 13 TAC 26 or for inclusion in the NRHP according to 36 CFR 60.4. Horizon recommends a finding of "no historic properties affected," and no further archeological work is recommended in connection with the proposed undertaking. However, human burials, both prehistoric and historic, are protected under the Texas Health and Safety Code. In the event that any human remains or burial objects are inadvertently discovered at any point during construction, use, or ongoing maintenance in the project area, even in previously surveyed areas, all work should cease immediately in the vicinity of the inadvertent discovery, and the THC should be notified immediately. Following completion of the project, all project records will be prepared for permanent curation at the Texas Archeological Research Laboratory (TARL). 


\section{TABLE OF CONTENTS}

Chapter

MANAGEMENT SUMMARY

1.0

INTRODUCTION

2.0

ENVIRONMENTAL SETTING.

2.1 Physiography and Hydrology 11

2.2 Geology and Geomorphology....... 11

2.3 Climate 12

$2.4 \quad$ Flora and Fauna 18

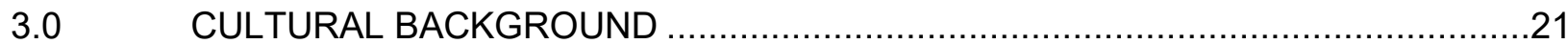

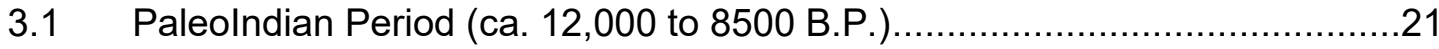

3.2 Archaic Period (ca. 8500 to 1200 B.P.) …..............................................22

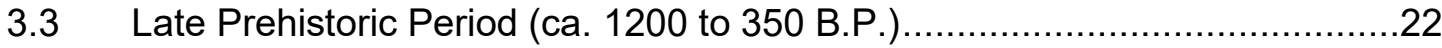

$3.4 \quad$ Historic Period (ca. 350 B.P. to Present) ...............................................22

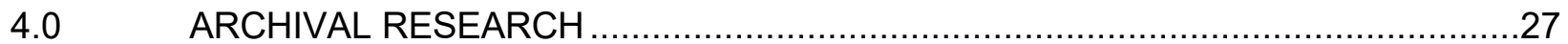

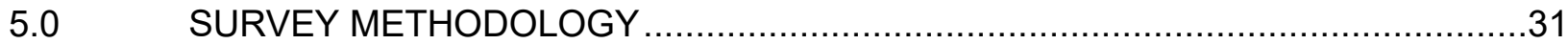

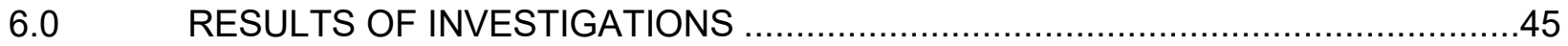

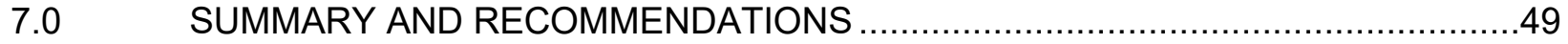

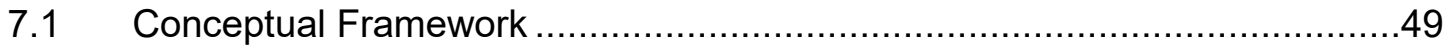

7.2 Eligibility Criteria for Inclusion in the National Register of Historic Places .....50

7.3 Eligibility Criteria for Listing as a State Antiquities Landmark.....................51

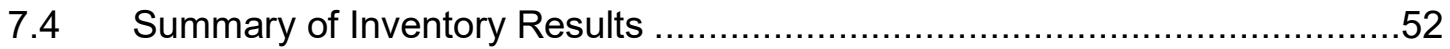

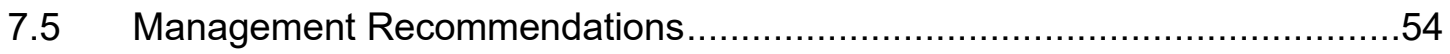

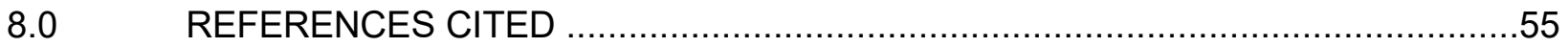

APPENDIX A: Shovel Test Data

APPENDIX B: Backhoe Trenching Data 


\section{LIST OF FIGURES}

Page

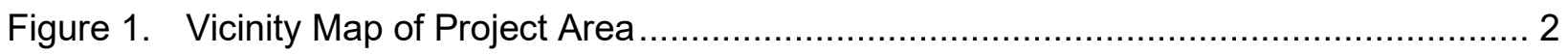

Figure 2. Location of West Interceptor (Options A and B) on USGS Topographic Map............ 3

Figure 3. Location of Reclaimed Water Line on USGS Topographic Map ............................. 4

Figure 4. Location of Facility Expansion and Effluent Pond on USGS Topographic Map ......... 5

Figure 5. Location of West Interceptor (Options A and B) on Aerial Photograph ..................... 6

Figure 6. Location of Reclaimed Water Line on Aerial Photograph ..................................... 7

Figure 7. Location of Reclamation Facility and Effluent Pond on Aerial Photograph ................ 8

Figure 8. Soils Mapped within West Interceptor (Options A and B) ..................................13

Figure 9. Soils Mapped within Reclaimed Water Line ...................................................14

Figure 10. Soils Mapped within Water Reclamation Facility and Effluent Pond ........................15

Figure 11. Known Cultural Resources within 1.0 Mile of Project Area ..................................28

Figure 12. Southern End of West Interceptor (Facing Southeast) .......................................32

Figure 13. Upper Terrace in Southeastern Portion of West Interceptor (Facing North) .............32

Figure 14. Onion Creek in Central Portion of West Interceptor (Facing Northeast) ...................33

Figure 15. Limestone Step in Central Portion of West Interceptor (Facing North) …..................33

Figure 16. Lower Terrace on West Interceptor Option A (Facing South) ................................34

Figure 17. Lower Terrace on West Interceptor Option B (Facing Southeast) ...........................34

Figure 18. Eastern Portion of Reclaimed Water Line Paralleling FM 12 (Facing North) ............35

Figure 19. Eastern Portion of Reclaimed Water Line Paralleling FM 12 (Facing North) .............35

Figure 20. Western End of Reclaimed Water Line (Facing North) .........................................36

Figure 21. Existing Water Reclamation Facility Expansion Area (Note Existing Reclamation Facility at Right) (Facing North-Northeast)...........................................................37

Figure 22. Proposed Effluent Pond Area (Facing Southeast)................................................

Figure 23. Locations of Shovel Tests Excavated on West Interceptor (Option A and B) ............39

Figure 24. Locations of Shovel Tests Excavated on Reclaimed Water Line ............................40

Figure 25. Locations of Shovel Tests on Reclamation Facility and Effluent Pond .....................41

Figure 26. Locations of Backhoe Trenches Excavated on West Interceptor.............................42

Figure 27. Location of Chert Flake Found on West Interceptor (Facing South) ........................47

Figure 28. View of Chert Flake and Rabdotus Snail Shell.................................................4 
Intensive Cultural Resources Survey of Proposed Dripping Springs

Wastewater System Improvements Project (EID 1), Dripping Springs, Hays County, Texas

\section{LIST OF TABLES}

Page

Table 1. Summary of Mapped Soils within Project Area ...............................................16

Table 2. Summary of Cultural Resources within 1.0 Mile of Project Area............................29 



\subsection{INTRODUCTION}

Horizon Environmental Services, Inc. (Horizon) was selected by the City of Dripping Springs to conduct an intensive cultural resources inventory survey and assessment of the proposed Dripping Springs Wastewater System Improvements Project (EID 1) in Dripping Springs, Hays County, Texas (USACE Project No. SWF-2020-00075). This survey represents the first phase of a larger project involving the proposed construction of wastewater system improvements in Dripping Springs. The current phase of the project would involve three separate components (Figures 1 to 7 ):

- West Interceptor-This segment would extend approximately 3.1 kilometers (1.9 miles) along the edges of Onion Creek, beginning at a small tributary of Onion Creek located approximately 0.5 kilometer $(0.3$ mile) west-northwest of the Farm-toMarket (FM) Road 190 bridge on the northwestern end and ending approximately 0.3 kilometer ( 0.2 mile) south of Needham Road. Two alternate rights-of-way (ROW) (designated herein referred to as Option A and Option B) were under consideration at the time of the survey. Option A extends approximately 0.8 kilometer $(0.5$ mile $)$ in length along the northern side of Onion Creek, and Option B extends approximately 0.6 kilometer $(0.4$ mile) along the southern side of the creek. Both routes were surveyed for cultural resources; however, Option A is the currently preferred alternative. For purposes of the cultural resources survey, the proposed West Interceptor segment measures a total of 3.7 kilometers (2.3 miles) in length, inclusive of both the Option A and Option B alternatives, within a linear ROW measuring a maximum of 30.5 meters (100.0 feet) in width, covering an area of approximately 11.3 hectares (27.9 acres).

- Reclaimed Water Line-This segment would extend approximately 1.3 kilometers (0.8 mile) in length beginning at a tributary of Onion Creek approximately 0.2 kilometer ( 0.1 mile) east of Needham Road at the end of a private driveway and extending southeastward to a point roughly 0.2 kilometer $(0.1$ mile) north of the intersection of FM 12 and FM 150. Approximately the southeastern half of this segment would be constructed within the existing ROW of FM 12 on the western side of the road. For the purposes of the cultural resources survey, the proposed Reclaimed Water Line would measure 1.3 kilometers ( 0.8 mile) in length by 30.5 meters ( 100.0 feet) in width, covering an area of approximately 3.9 hectares ( 9.7 acres). 


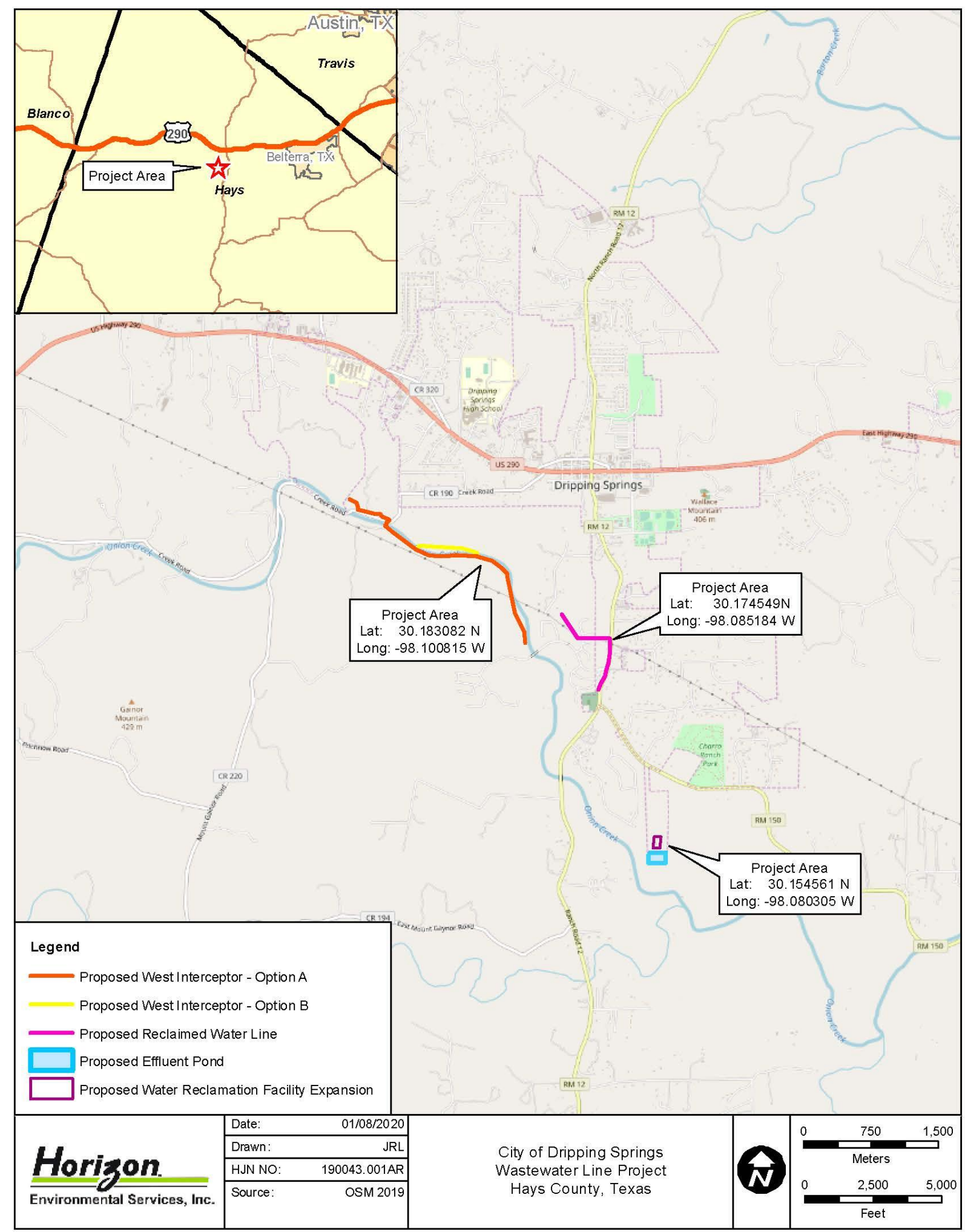

Figure 1. Vicinity Map of Project Area 


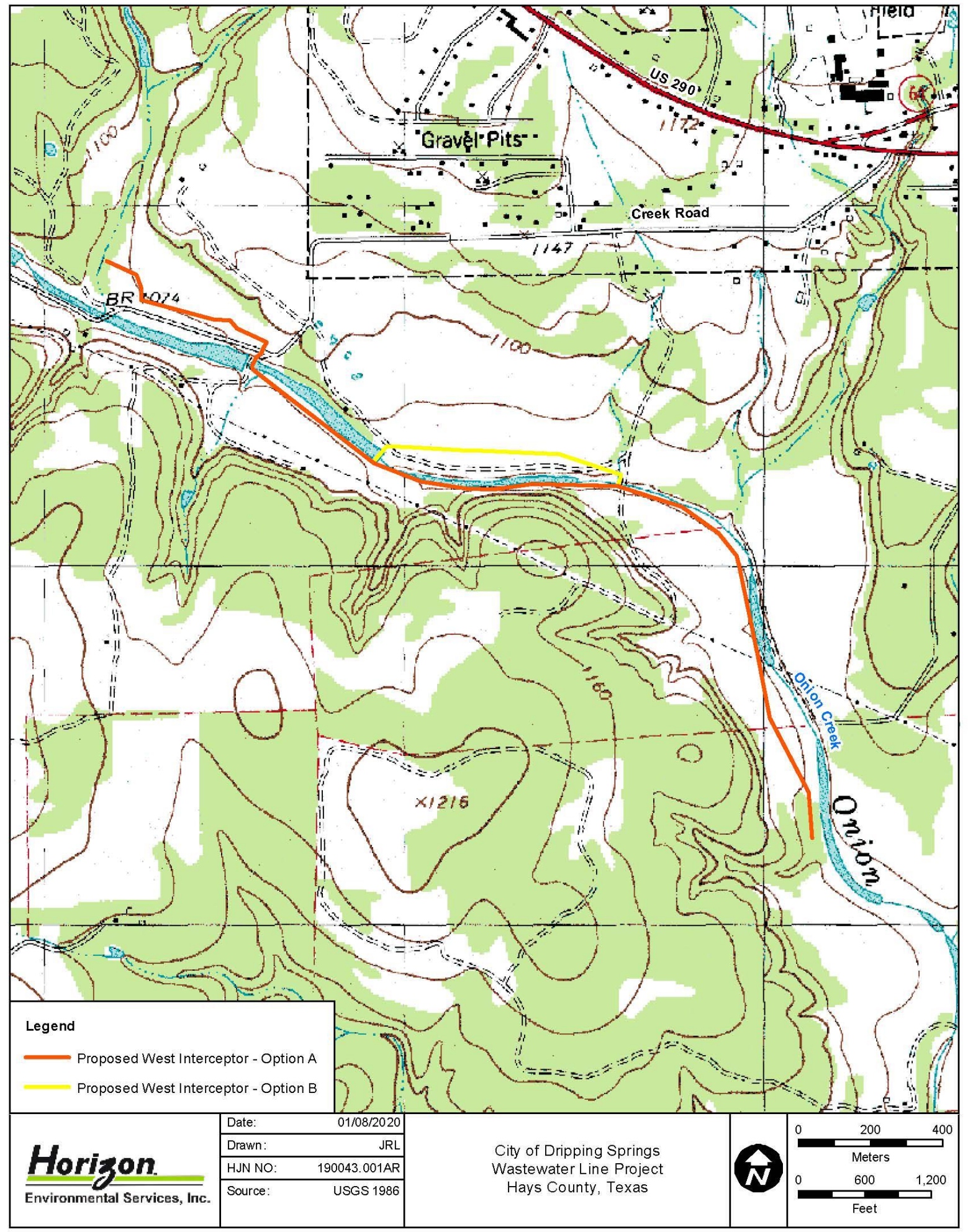

Figure 2. Location of West Interceptor (Options A and B) on USGS Topographic Map 


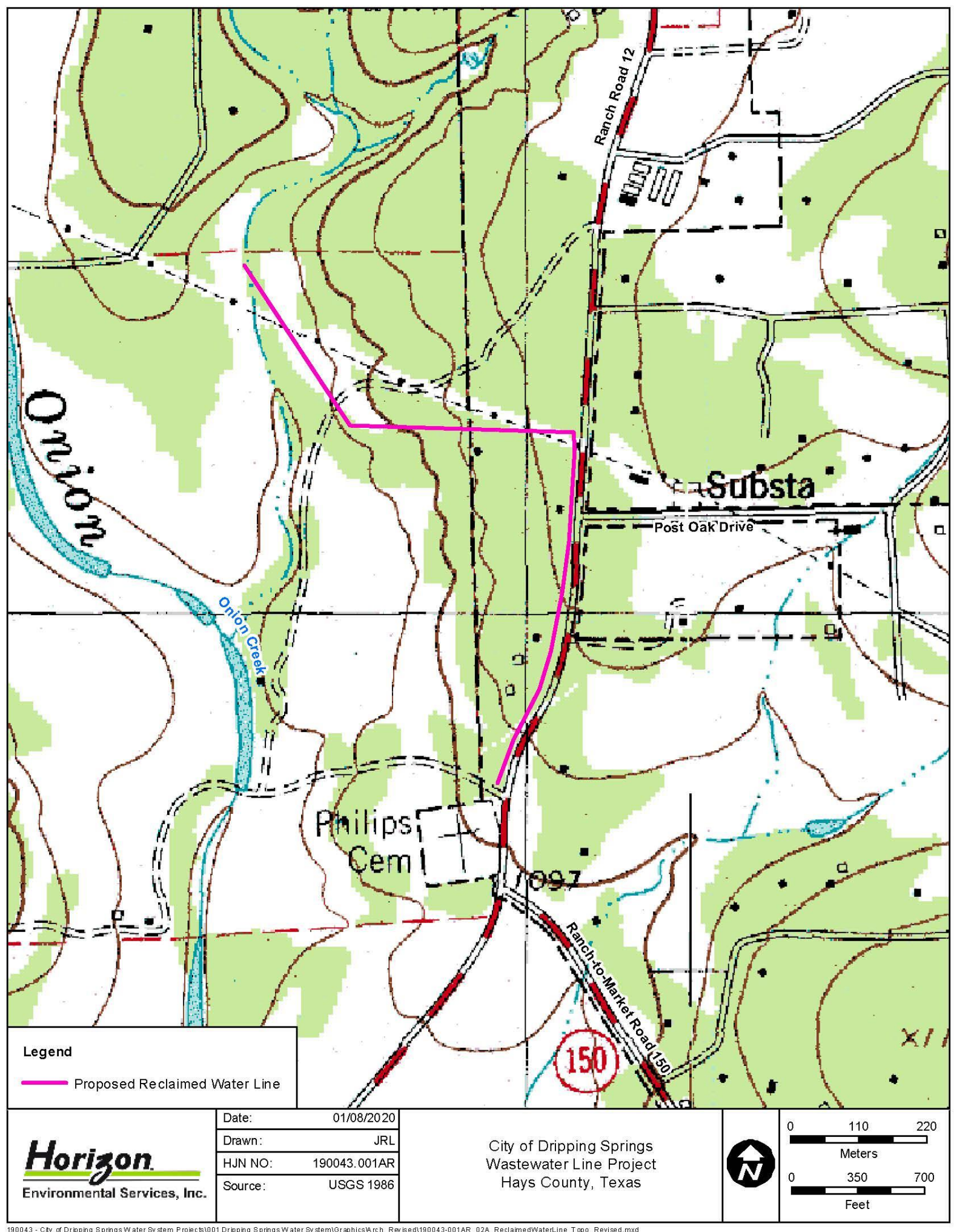

Figure 3. Location of Reclaimed Water Line on USGS Topographic Map 


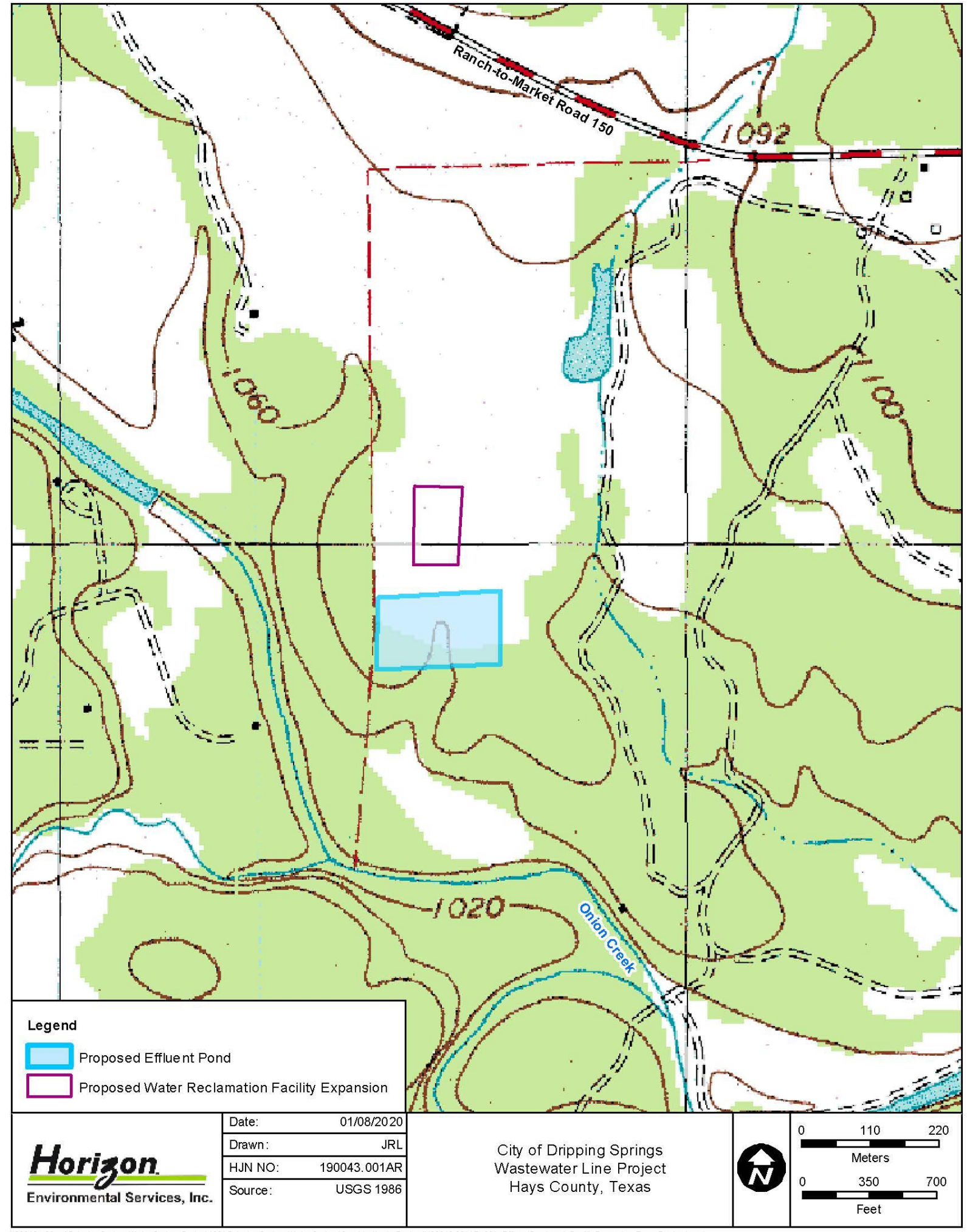

Figure 4. Location of Facility Expansion and Effluent Pond on USGS Topographic Map 


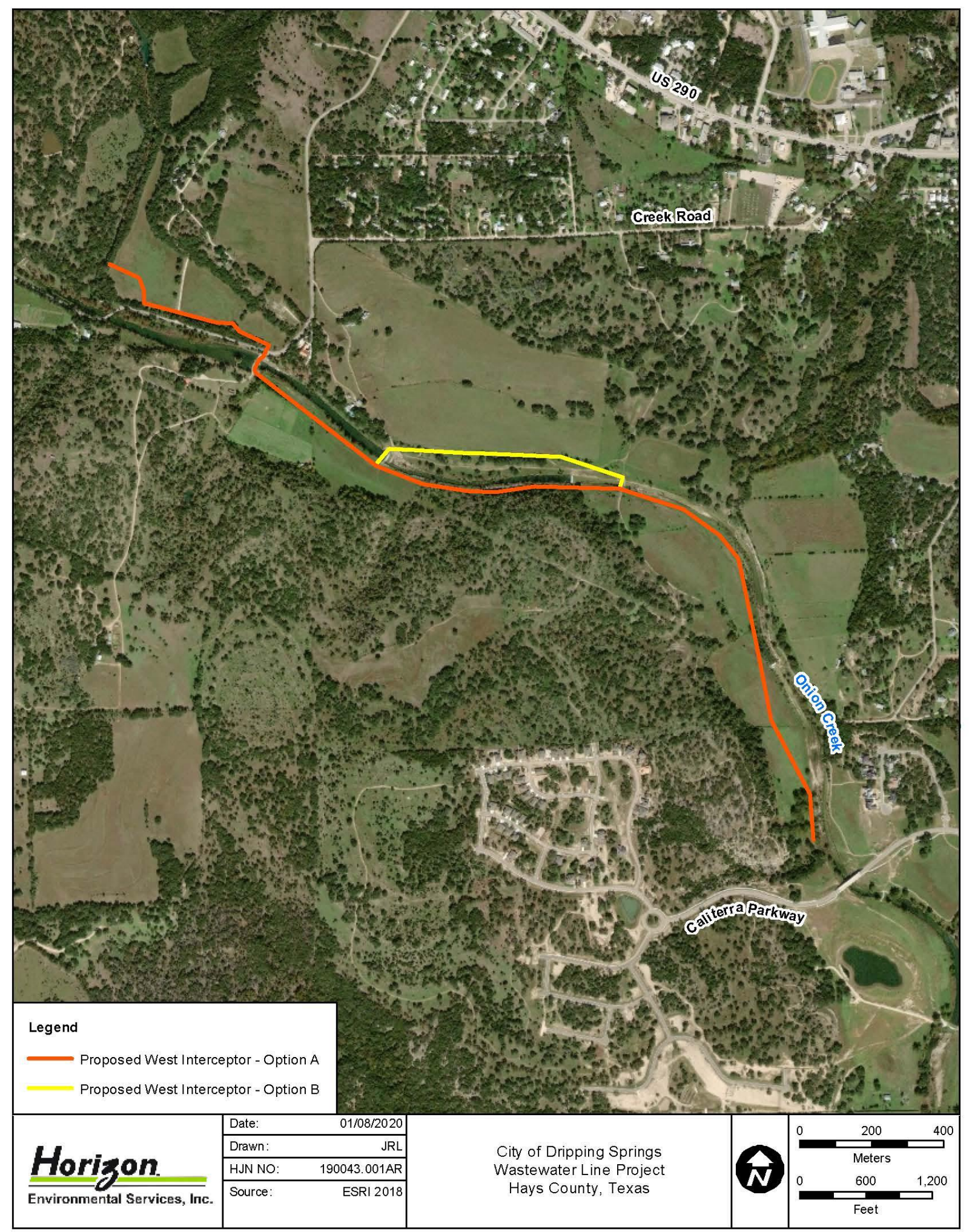

Figure 5. Location of West Interceptor (Options A and B) on Aerial Photograph 


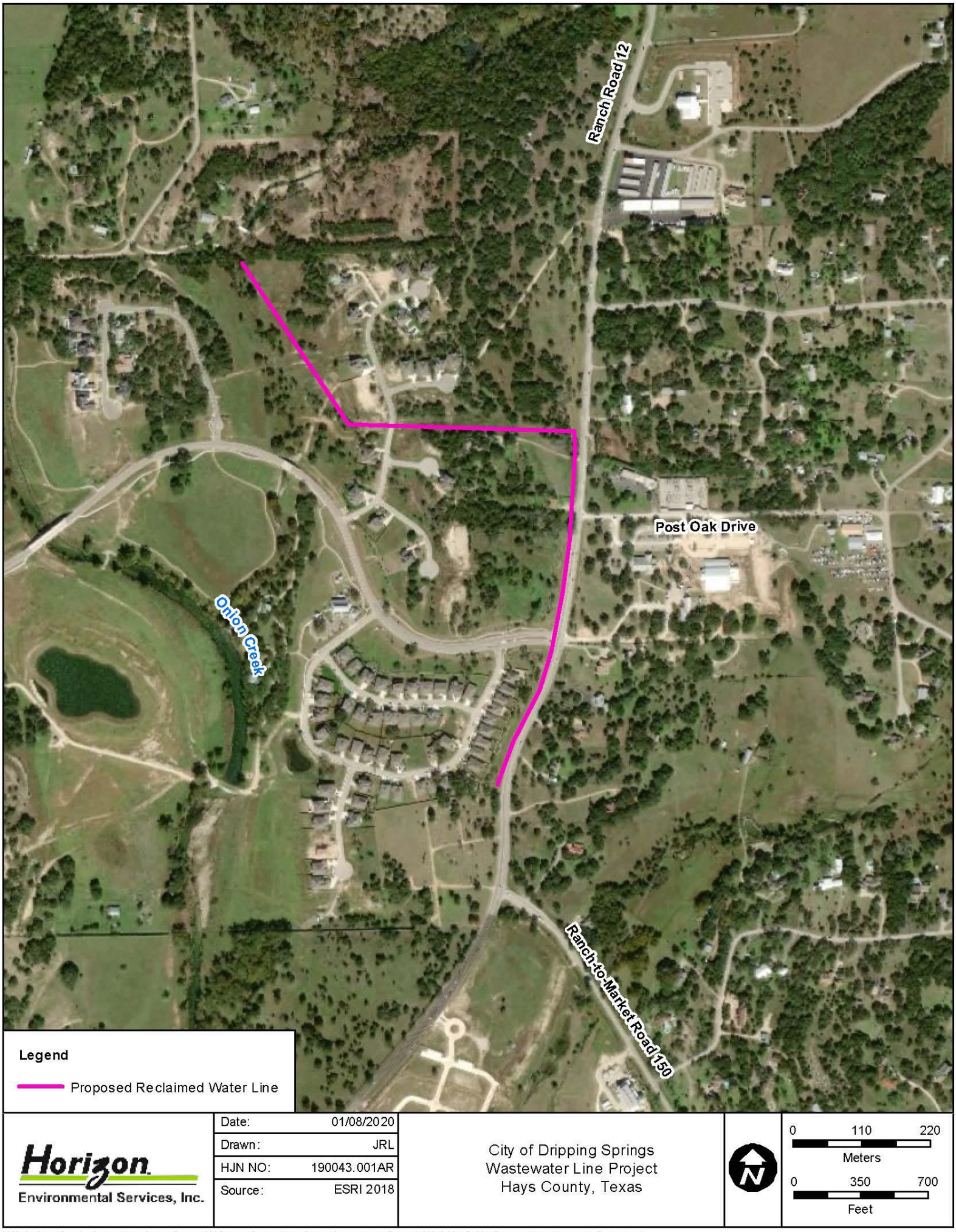

Figure 6. Location of Reclaimed Water Line on Aerial Photograph 




Figure 7. Location of Reclamation Facility and Effluent Pond on Aerial Photograph 
Intensive Cultural Resources Survey of Proposed Dripping Springs

Wastewater System Improvements Project (EID 1), Dripping Springs, Hays County, Texas

- Water Reclamation Facility Expansion and Effluent Pond-This segment would consist of the construction of a proposed new effluent pond measuring approximately 180.0 meters ( 590.6 feet) east to west by 95.0 meters ( 311.7 feet) north to south and covering an area of roughly 2.3-hectares (5.7 acres). The proposed effluent pond would be located in an open pasture immediately south of an existing water reclamation plant at the southern end of a private driveway that extends southward from FM 150 east of the Howard Ranch residential subdivision. The project would also involve the expansion of the existing water reclamation facility from its existing 0.6-hectare (1.4-acre) lot northward onto an adjacent 0.4-hectare (0.9-acre) tract currently used as a septic field, and the proposed expanded plant would cover a total are of 1.0 hectare (2.3 acres). Combined, the proposed water reclamation facility expansion and effluent pond cover an area approximately 3.3 hectares ( 8.0 acres) total.

Together, these three proposed components of the Dripping Springs Wastewater System Improvements Project (EID 1) cover an area of 18.5 hectares (45.6 acres).

The proposed undertaking would be sponsored by the City of Dripping Springs, a public subdivision of the state of Texas. As a political subdivision of the state of Texas, the project would fall under the jurisdiction of the Antiquities Code of Texas (Natural Resources Code, Title 9, Chapter 191). In addition, the project would utilize funding provided by the Clean Water State Revolving Fund (CWSRF) program, which is a federal-state partnership between the US Environmental Protection Agency (US EPA) and the state of Texas. As the US EPA is a federal agency, the project would also fall under the jurisdiction of Section 106 of the National Historic Preservation Act (NHPA) of 1966, as amended. As the proposed project represents a publicly sponsored undertaking, the project sponsor is required to provide the Texas Historical Commission (THC), which serves as the State Historic Preservation Office (SHPO) for the state of Texas, with an opportunity to review and comment on the project's potential to adversely affect historic properties listed on or considered eligible for listing on the National Register of Historic Places (NRHP) under the NHPA and for designation as State Antiquities Landmarks (SAL) under the Antiquities Code of Texas.

From October 1 to 3, on November 4, and on November 22, 2019, Horizon archeologists Jesse Dalton, McKinzie Froese, Amy Goldstein, Elizabeth Sefton, and Jared Wiersema conducted an intensive cultural resources survey of the project area, including pedestrian walkover with shovel testing and backhoe trenching. The survey was performed under the supervision of Jeffrey D. Owens, who served as Principal Investigator, under Texas Antiquities Permit No. 9114. The purpose of the survey was to locate any significant cultural resources that potentially would be impacted by the proposed undertaking. The cultural resources investigation consisted of an archival review, an intensive pedestrian survey of the project area, and the production of a report suitable for review by the SHPO in accordance with the THC's Rules of Practice and Procedure, Chapter 26, Section 26, and the Council of Texas Archeologists (CTA) Guidelines for Cultural Resources Management Reports. 
Following this introductory chapter, Chapters 2.0 and 3.0 present the environmental and cultural backgrounds, respectively, of the project area. Chapter 4.0 describes the results of background archival research, and Chapter 5.0 discusses cultural resources survey methods Chapter 6.0 presents the results of the cultural resources survey, and Chapter 7.0 presents cultural resources management recommendations for the project. Chapter 8.0 lists the references cited in the report, Appendix A summarizes shovel test data, and Appendix B contains backhoe trenching data. 


\subsection{ENVIRONMENTAL SETTING}

\subsection{Physiography AND HYdRology}

The project area is located in southwestern Dripping Springs in north-central Hays County, Texas, near the boundary of two significant physiographic provinces-the Edwards Plateau and the Blackland Prairie. The Blackland Prairie, the narrow physiographic zone situated between the Edwards Plateau on the west and the Gulf Coastal Plain on the east, is a low, rolling land that extends in a narrow band along the eastern edge of the Balcones fault zone from the Red River Valley in northeastern Texas to the southern edge of the Edwards Plateau. This is an area of low topographic relief and poor drainage in which water often ponds after rainstorms and streams flow at very gentle gradients. The Edwards Plateau and Balcones Escarpment are associated with a great fault system that arcs across Texas to form a distinct boundary between uplands composed primarily of limestone bedrock and lower plains composed mostly of softer rocks. In places, this boundary is marked by an abrupt scarp (the Balcones Escarpment) and in others by a more gradational ramp, but the entire length of this transition zone is a major ecotone in terms of topography, bedrock, hydrology, soil, vegetation, and animal life.

Physiographically, the project area is situated on the stream terraces and adjacent uplands of Onion Creek. Geomorphological characteristics of the floodplain and terraces of Onion Creek include deep erosional gullies, cut banks, and extensive limestone gravel bars containing dense, deep deposits of river-rolled gravels overlain by a shallow A horizon composed of hard, calcareous clay loam. Adjacent upland landforms and hillslopes consist of shallowly buried or exposed degrading limestone bedrock overlain in some areas by clayey sediment. Elevations within the project area range from approximately 321.6 to 333.5 meters (1,055 to 1,094.0 feet) amsl.

Hydrologically, the project area is situated within the Guadalupe River basin. Hays County's numerous streams generally flow in an easterly direction. The principal waterways are Bear, Cypress, and Onion creeks as well as the Blanco and San Marcos rivers. The project area is situated on the terraces of Onion Creek, which flows generally eastward, discharging into the Colorado River in southeastern Austin in Travis County. The Colorado river continues southeastward across the coastal plain, ultimately discharging into the Gulf of Mexico at Matagorda Bay. 


\subsection{Geology AND GeOMORPhology}

Hays County is underlain by a thick sequence of Cretaceous-age sedimentary rock strata, while areas of alluvium may be present adjacent to major streams and rivers. Geologically, the majority of the West Interceptor project area is situated on recent Holocene-age alluvium (Qal) along Onion Creek, which consists of low terrace deposits composed of sand, silt, clay, and gravel (USGS 2020). A small area at the western end of the West Interceptor segment and all of the remaining segments of the project area (i.e., the Reclaimed Water Line, water reclamation facility, and effluent pond) are situated on the Cretaceous-age Upper Glen Rose Limestone Formation $(\mathrm{Kgr}[\mathrm{u}])$, which consists of shallow clay sediments over limestone, dolomite, and marl bedrock (USGS 2020).

The project area traverses a mosaic of soil units composed predominantly of shallow clayey and loamy residuum weathered in situ from underlying limestone and marl bedrock or calcareous loamy and clayey alluvium of Pleistocene age on ancient terrace structures (Figures 8 to 10; Table 1) (NRCS 2019). Limited portions of the southeastern part of the West Interceptor segment of the project area on the terraces of Onion Creek are situated on loamy alluvial deposits of Quaternary or Holocene age (Figures 8 to 10; Table 1) (NRCS 2019).

While aboriginal cultural resources are commonly encountered in deep alluvial sediments adjacent to major streams in Central Texas, the antiquity of the Cretaceous-age upland bedrockderived sediments and Pleistocene-age alluvial deposits that characterize the majority of the project area suggests that any aboriginal cultural resources present would be on the modern ground surface or within shallowly buried contexts in erosional settings that lack depth and integrity. Limited portions of the West Interceptor segment of the project area are situated on Quaternary or Holocene-age sediments with at least some potential to contain archeological deposits at more substantial depths. Historic-age resources may occur in virtually any physiographic setting but are most common in urban settings along roads and in rural areas suitable for agriculture. The location of the project area adjacent to Onion Creek near the city of Dripping Springs suggests that the project area as a whole possesses at least moderate potential for historic-age architectural and archeological resources.

\subsection{Climate}

Evidence for climatic change from the Pleistocene to the present is most often obtained through studies of pollen and faunal sequences (Bryant and Holloway 1985; Collins 1995). Bryant and Holloway (1985) present a sequence of climatic change for nearby east-central Texas from the Wisconsin Full Glacial period (22,500 to 14,000 B.P.) through the Late Glacial period $(14,000$ to 10,000 B.P.) to the Post-Glacial period (10,000 B.P. to present). Evidence from the Wisconsin Full Glacial period suggests that the climate in east-central Texas was considerably cooler and more humid than at present. Pollen data indicate that the region was more heavily forested in deciduous woodlands than during later periods (Bryant and Holloway 1985). The Late Glacial period was characterized by slow climatic deterioration and a slow warming and/or drying trend (Collins 1995). In east-central Texas, the deciduous woodlands were gradually replaced by grasslands and post oak savannas (Bryant and Holloway 1985). During the Post-Glacial period, 
Intensive Cultural Resources Survey of Proposed Dripping Springs

Wastewater System Improvements Project (EID 1), Dripping Springs, Hays County, Texas



Figure 8. Soils Mapped within West Interceptor (Options A and B) 


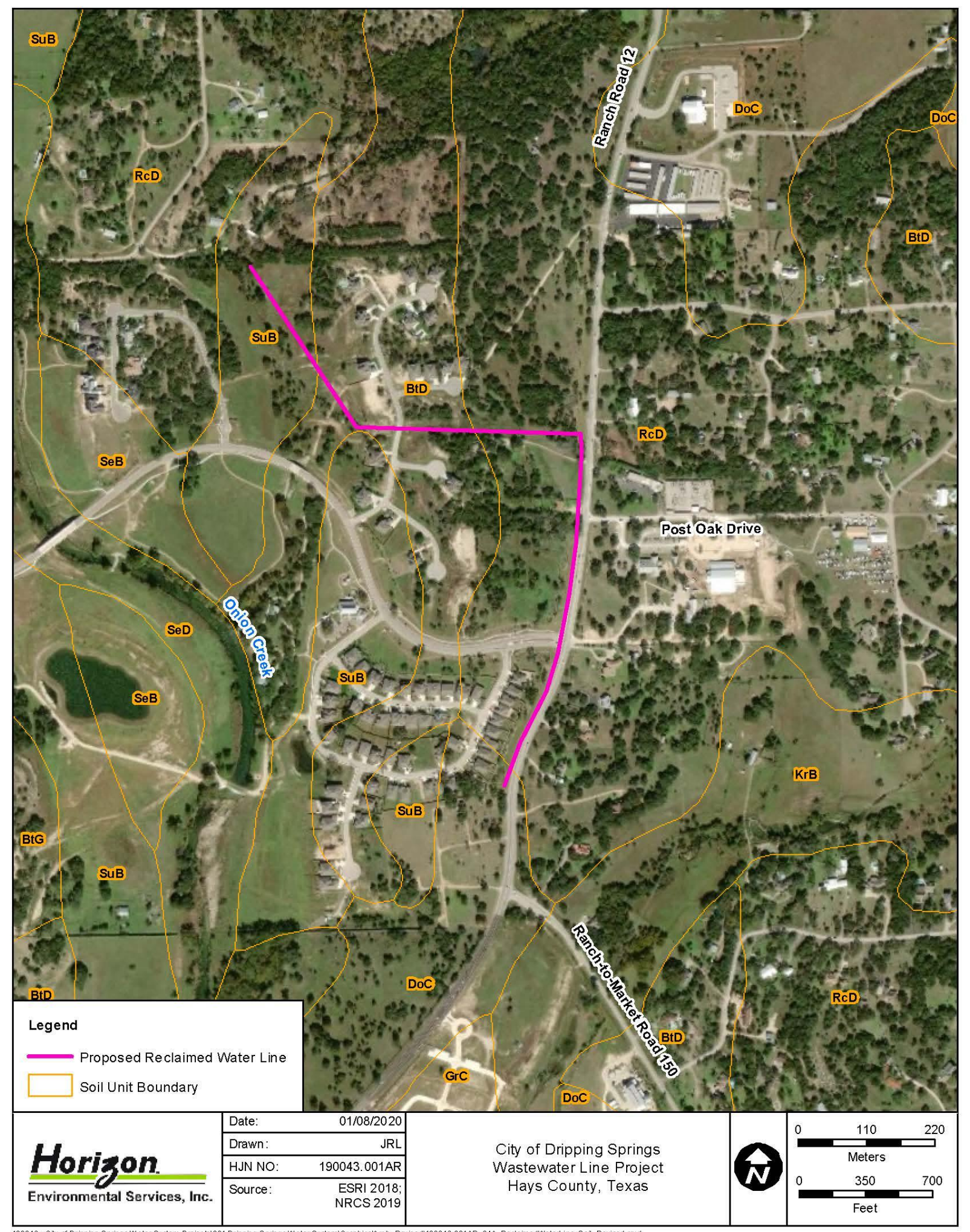

Figure 9. Soils Mapped within Reclaimed Water Line 
Intensive Cultural Resources Survey of Proposed Dripping Springs

Wastewater System Improvements Project (EID 1), Dripping Springs, Hays County, Texas

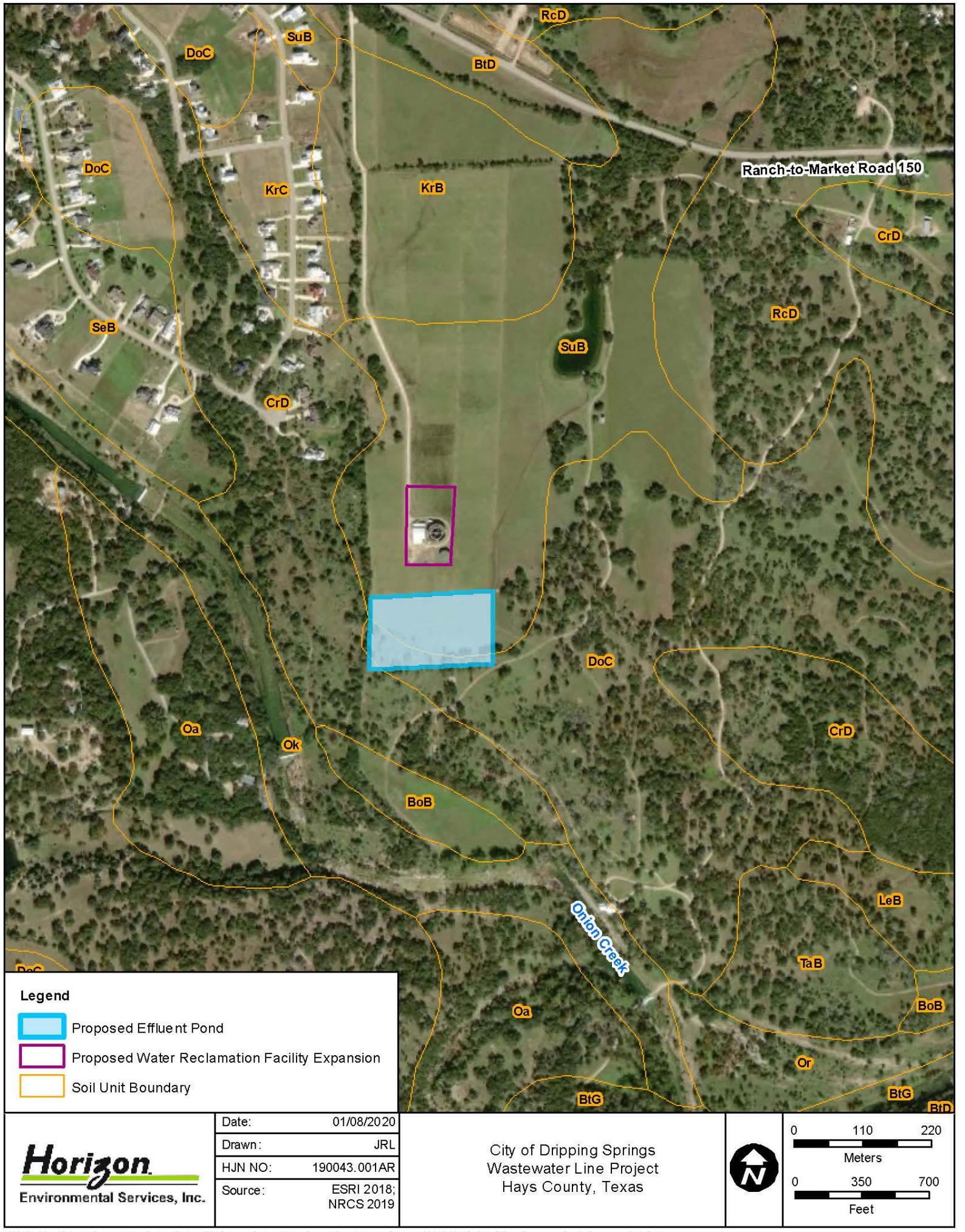

Figure 10. Soils Mapped within Water Reclamation Facility and Effluent Pond 
Table 1. Summary of Mapped Soils within Project Area

\begin{tabular}{|c|c|c|c|}
\hline $\begin{array}{l}\text { NRCS } \\
\text { Soil Code }\end{array}$ & Soil Name & Parent Material & $\begin{array}{l}\text { Typical Profile } \\
\text { (inches) }\end{array}$ \\
\hline BtD & $\begin{array}{l}\text { Brackett-Rock outcrop- } \\
\text { Comfort complex, } \\
1 \text { to } 8 \% \text { slopes }\end{array}$ & $\begin{array}{l}\text { Brackett: } \\
\text { Shallow clayey residuum formed from } \\
\text { limestone of the Cretaceous-age Glen } \\
\text { Rose Formation on ridges } \\
\text { Rock outcrop: } \\
\text { Limestone bedrock on ridges } \\
\text { Comfort: } \\
\text { Clayey residuum derived from Lower } \\
\text { Cretaceous-age dolomitic limestone } \\
\text { on ridges }\end{array}$ & $\begin{array}{l}\text { Brackett: } \\
\text { 0-6: Clay loam }(\mathrm{A}) \\
\text { 6-14: Clay loam }(\mathrm{Bk}) \\
\text { 14-60: Limestone bedrock }(\mathrm{Cr}) \\
\text { Rock outcrop: } \\
\text { 0-48: Bedrock }(\mathrm{R}) \\
\text { Comfort: } \\
\text { 0-5: Clay }(\mathrm{A}) \\
\text { 5-17: Clay }(\mathrm{Bt}) \\
\text { 17-27: Clay }(\mathrm{R})\end{array}$ \\
\hline $\mathrm{CrD}$ & $\begin{array}{l}\text { Comfort-Rock outcrop } \\
\text { complex, } 1 \text { to } 8 \% \\
\text { slopes }\end{array}$ & $\begin{array}{l}\text { Comfort: } \\
\text { Residuum weathered from dolomitic } \\
\text { limestone on ridges } \\
\text { Rock outcrop: } \\
\text { Limestone bedrock on ridges }\end{array}$ & $\begin{array}{l}\text { Comfort: } \\
\text { 0-6: Very stony clay }(\mathrm{A}) \\
\text { 6-13: Extremely stony clay }(\mathrm{Bt}) \\
\text { 13-40: Bedrock }(\mathrm{R}) \\
\text { Rock outcrop: } \\
\text { 0-80: Bedrock }(\mathrm{R})\end{array}$ \\
\hline DoC & $\begin{array}{l}\text { Doss silty clay, moist, } \\
1 \text { to } 5 \% \text { slopes }\end{array}$ & $\begin{array}{l}\text { Calcareous loamy and clayey } \\
\text { residuum derived from marl and } \\
\text { weakly cemented limestone on hill } \\
\text { slopes }\end{array}$ & $\begin{array}{l}\text { 0-9: Silty clay }(\mathrm{A}) \\
\text { 9-17: Silty clay }(\mathrm{Bk}) \\
\text { 17-80: Bedrock }(\mathrm{Cr})\end{array}$ \\
\hline $\mathrm{GrC}$ & $\begin{array}{l}\text { Gruene clay, } \\
1 \text { to } 5 \% \text { slopes }\end{array}$ & $\begin{array}{l}\text { Clayey alluvium of Pleistocene age } \\
\text { over gravelly alluvium of Pleistocene } \\
\text { age on ridges }\end{array}$ & $\begin{array}{l}\text { 0-13: Clay } \\
\text { 13-22: Cemented material } \\
\text { 22-80: Stratified very gravelly } \\
\text { loam }\end{array}$ \\
\hline $\mathrm{KrB}$ & $\begin{array}{l}\text { Krum clay, } \\
1 \text { to } 3 \% \text { slopes }\end{array}$ & $\begin{array}{l}\text { Calcareous clayey alluvium derived } \\
\text { from interbedded chalk and marl on } \\
\text { stream terraces }\end{array}$ & $\begin{array}{l}\text { 0-16: Clay (A) } \\
\text { 16-58: Clay (Bk1) } \\
\text { 58-66: Clay (B2) } \\
\text { 66-80: Clay (Ck2)p }\end{array}$ \\
\hline LeB & $\begin{array}{l}\text { Lewisville silty clay, } \\
1 \text { to } 3 \% \text { slopes }\end{array}$ & $\begin{array}{l}\text { Calcareous clayey alluvium on stream } \\
\text { terraces }\end{array}$ & $\begin{array}{l}\text { 0-15: Silty clay }(\mathrm{A}) \\
\text { 15-38: Clay (Bk1) } \\
\text { 38-69: Clay (Bk2) }\end{array}$ \\
\hline $\mathrm{RcD}$ & $\begin{array}{l}\text { Real-Comfort-Doss } \\
\text { complex, } 1 \text { to } 8 \% \\
\text { slopes }\end{array}$ & 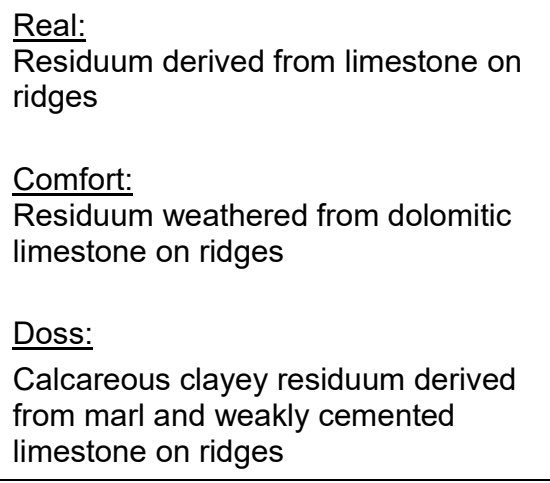 & $\begin{array}{l}\text { Real: } \\
\text { 0-4: Gravelly loam (A) } \\
\text { 4-14: Very gravelly loam (Ak) } \\
\text { 14-40: Bedrock (Crk) } \\
\text { Comfort: } \\
\text { 0-6: Very stony clay }(\mathrm{A}) \\
\text { 6-13: Extremely stony clay (Bt) } \\
\text { 13-40: Bedrock (R) } \\
\text { Doss: } \\
\text { 0-9: Clay loam (A) } \\
\text { 9-18: Clay loam (Bk) } \\
\text { 18-41: Bedrock (Crk) }\end{array}$ \\
\hline SeD & $\begin{array}{l}\text { Seawillow clay loam, } \\
3 \text { to } 8 \% \text { slopes }\end{array}$ & $\begin{array}{l}\text { Loamy alluvium of Quaternary age on } \\
\text { stream terraces }\end{array}$ & $\begin{array}{l}\text { 0-8: Clay loam } \\
\text { 8-38: Clay loam } \\
\text { 38-62: Clay loam }\end{array}$ \\
\hline
\end{tabular}


Intensive Cultural Resources Survey of Proposed Dripping Springs

Wastewater System Improvements Project (EID 1), Dripping Springs, Hays County, Texas

Table 1. Summary of Mapped Soils within Project Area (cont.)

\begin{tabular}{c|l|l|l}
\hline $\begin{array}{c}\text { NRCS } \\
\text { Soil Code }\end{array}$ & \multicolumn{1}{|c|}{ Soil Name } & \multicolumn{1}{c}{ Parent Material } & \multicolumn{1}{c}{$\begin{array}{c}\text { Typical Profile } \\
\text { (inches) }\end{array}$} \\
\hline \hline SuB & $\begin{array}{l}\text { Sunev clay loam, } \\
1 \text { to 3\% slopes }\end{array}$ & $\begin{array}{l}\text { Calcareous loamy alluvium on stream } \\
\text { terraces }\end{array}$ & $\begin{array}{l}0-11 \text { : Clay loam } \\
11-35: \text { Clay loam } \\
35-45: \text { Clay loam }\end{array}$ \\
\hline
\end{tabular}

Source: NRCS (2019)

NRCS $=$ Natural Resources Conservation Service

the east-central Texas environment appears to have been more stable. The deciduous forests had long since been replaced by prairies and post oak savannas. The drying and/or warming trend that began in the Late Glacial period continued into the mid-Holocene, at which point there appears to have been a brief amelioration to more mesic conditions lasting from roughly 6,000 to 5,000 B.P. Recent studies by Bryant and Holloway (1985) indicate that modern environmental conditions in east-central Texas were probably achieved by 1,500 years ago.

Hays County is located within the south-central climatic division. The modern climate is typically dry to subhumid with long, hot summers and short, mild winters. The climate is influenced primarily by tropical Maritime air masses from the Gulf of Mexico, but it is modified by polar air masses. Tropical Maritime air masses predominate throughout spring, summer, and fall. Modified polar air masses are dominant in winter and provide a continental climate characterized by considerable variations in temperature.

On average throughout the past century, precipitation and temperature in Texas manifest regional clines with mean annual precipitation totals declining fairly regularly from east to west and mean annual temperature declining equally evenly from northwest to southeast (Larkin and Bomar 1983). In Central Texas, climate has fluctuated from subtropical humid to subtropical subhumid. Average annual precipitation totals 81.3 centimeters (32.0 inches) and temperature averages $19^{\circ}$ degreesCelsius $\left({ }^{\circ} \mathrm{C}\right)\left(67^{\circ}\right.$ degrees Fahrenheit $\left.\left[{ }^{\circ} \mathrm{F}\right]\right)$ annually, ranging from $36^{\circ} \mathrm{C}$ $\left(96^{\circ} \mathrm{F}\right)$ in August (the warmest month) to $15^{\circ} \mathrm{C}\left(59^{\circ} \mathrm{F}\right)$ in January (the coldest month). During this time, however, drier periods lasting from three to seven years, when total annual rainfall ranged from 30.5 to 63.5 centimeters ( 12.0 to 25.0 inches), were followed by abnormally wet years with 114.3 to 127.0 centimeters ( 45.0 to 50.0 inches) of rainfall.

Two annual precipitation peaks, which typically occur in May and September, are associated with frontal storms that form when southward-moving cool air masses collide with warm, moist air masses moving inland from the Gulf of Mexico (Bomar 1983; Carr 1967). The topographic discontinuity along the Balcones Escarpment lies directly in the path of the Gulf storm trace and increases the lift in convective storms to produce extreme amounts of rainfall. Two extreme examples are the excess of 91.4 centimeters (36.0 inches) of rain that fell within an 18hour period in the vicinity of Thrall, Texas, in September 1921, and the 55.9-centimeters (22.0inches) deluge that fell in less than three hours near O'Harris, Texas, in May 1935. Lower rainfall amounts are characteristic of winter and late summer. In winter, frontal storms pass so frequently that there is little time for moisture to increase, and prevailing upper-level winds from west to east 
often dominate over meridional flow, meaning that much of the available moisture is derived from the Pacific rather than from the Gulf of Mexico. In summer, cool fronts rarely penetrate into the region, and rainfall occurs primarily as localized, thermal convective storms.

\subsection{FLORA AND FAUNA}

The project area is situated in the southwestern portion of the Texan biotic province (Blair 1950), an intermediate zone between the forests of the Austroriparian and Carolinian provinces and the grasslands of the Kansan, Balconian, and Tamaulipan provinces (Dice 1943). Some species reach the limits of their ecological range within the Texan province. The boundary, characterized as "approximate," between Blair's (1950) Texan and Balconian provinces passes through western Williamson County, northwest of the project area. Rainfall in the Texan province is barely in excess of water need, and the region is classified by Thornwaite (1948) as a $\mathrm{C}_{2}$ (moist subhumid) climate with a moisture surplus index of from 0 to $20 \%$.

Edaphic controls on vegetation types are important in the Texan biotic province, which is located near the border between moisture surplus and moisture deficiency. Sandy soils support oak-hickory forests dominated by post oak (Quercus stellata), blackjack oak (Q. marilandica), and hickory (Carya buckleyi). Clay soils originally supported a tall-grass prairie, but much of this soil type has been placed under cultivation. Dominant tall-grass prairie species include western wheatgrass (Agrophyron smithii), silver beardgrass (Andropogon saccharoides), little bluestem (Andropogon scoparius), and Texas wintergrass (Stipa leucotricha). Major areas of oak-hickory forest include the Eastern and Western Cross Timbers, and major tall-grass prairie areas include the Blackland, Grand, and Coastal prairies. Some characteristic associations of the Austroriparian province occur locally in the Texan province, such as a mixed stand of loblolly pine (Pinus taeda) and blackjack and post oak in Bastrop County, as well as a series of peat and bog marshes distributed in a line extending from Leon to Gonzales counties.

The fauna associated with this region are represented by a mixture of species from the Austroriparian, Tamaulipan, Chihuahuan, Kansan, Balconian, and Texan biotic provinces. At least 49 species of mammals occur in the Texan province, including Virginia opossum (Didelphis virginiana), eastern mole (Scalopus aquaticus), fox squirrel (Sciurus niger), desert pocket gopher (Geomys breviceps), fulvous harvest mouse (Reithrodontomys fulvescens), white-footed mouse (Peromyscus leucopus), hispid cotton rat (Sigmodon hispidus), eastern cottontail rabbit (Sylvilagus floridanus), raccoon (Procyon lotor), striped skunk (Mephitis mephitis), ground squirrel (Citellus tridecemlineatus), white-tailed deer (Odocoileus virginiana), hispid pocket mouse (Perognathus hispidus), deer mouse (Peromyscus maniculatus), black-tailed jackrabbit (Lepus californicus), pygmy mouse (Baiomys taylori), 9-banded armadillo (Dasypus novemcinctus), and jaguar (Felis onca). Both species of Terrapene known from the Austroriparian province-eastern box turtle ( $T$. Carolina) and desert box turtle ( $T$. ornata)-occur in the Texan.

Sixteen species of lizards, including seven grassland and nine forest species, are also found, including green anole (Anolis carolinensis), eastern fence lizard (Sceloporus undulates), common ground skink (Leiolopisma laterale), and glass snake (Ophiosaurus ventralis) (grassland species), as well as collared lizard (Crotaphytus collaris), Texas spiny lizard (Sceloporus olivaceous), Texas horned lizard (Phrynosoma cornutum), and Great Plains skink (Eumeces 
obsoletus) (forest species). Only five species of urodele fauna are known from this area, including small-mouthed salamander (Ambystoma texanum), tiger salamander (Ambystoma tigrinum), and eastern lesser siren (Siren intermedia), and the Texan province acts as a barrier to urodele distribution between the endemic Balconian province fauna to the west and the Austroriparian fauna to the east.

Anuran fauna is composed primarily of Austroriparian or otherwise widely distributed species, including eastern spadefoot toad (Scaphiopus holbrookii), Gulf Coast toad (Bufo valliceps), Woodhouse's toad (Bufo woodhousii), southern cricket frog (Acris gryllus), southern chorus frog (Pseudacris nigrita), gray treefrog (Hyla versicolor), green treefrog (Hyla cinerea), North American bullfrog (Rana catesbeiana), northern leopard frog (Rana pipiens), and narrowmouthed toad (Microhyla carolinensis). Additional anuran species that fail to cross from the Texan into the Austroriparian province include Pacific tree frog (Pseudacris clarkia), Strecker's chorus frog (Pseudacris streckeri), and striped whipsnake (Microhyla olivacea). Other reptile and amphibian species common to this biotic zone include six-lined racerunner (Aspidoscelis sexlineata), rat snake (Ptyas mucosus), eastern hognose snake (Heterodon platirhinos), rough green snake (Opheodrys aestivus), copperhead (Agkistrodon contortrix), western diamondback rattlesnake (Crotalus atrox), Blanchard's cricket frog (Acris crepitans), diamondback water snake (Nerodia rhombifer), and Houston toad (Bufo houstonensis).

Common bird species include northern bobwhite (Colinus virginianus), eastern meadowlark (Sturnella magna), mourning dove (Zenaida macroura), killdeer (Charadrius vociferus), field sparrow (Spizella pusilla), red-tailed hawk (Buteo jamaicensis), turkey vulture (Cathartes aura), belted kingfisher (Ceyrle alcyon), and mockingbird (Mimus polyglottos).

Small herds of bison and antelope were common during the late prehistoric and early historic periods, but these species are no longer native to this region (Jurney et al. 1989:13-14). 



\subsection{CULTURAL BACKGROUND}

The project area is located within Prewitt's $(1981,1985)$ Central Texas Archeological Region. The indigenous human inhabitants of Central Texas practiced a generally nomadic hunting and gathering lifestyle throughout all of prehistory, and, in contrast to much of the rest of North America, mobility and settlement patterns do not appear to have changed markedly through time in this region.

\subsection{Paleolndian Period (CA. 12,000 to 8500 B.P.)}

The initial human occupations in the New World can now be confidently extended back before 16,000 B.P. (Dillehay et al. 2008; Meltzer 2009; Rodrigues et al. 2016; Williams et al. 2018). Evidence from Meadowcroft Rockshelter in Pennsylvania suggests that humans were present in Eastern North America as early as 14,000 to 16,000 years ago (Adovasio et al. 1990), as well as discoveries at Monte Verde in Chile provide unequivocal evidence for human occupation in South America by at least 14,000 years ago (Dillehay et al. 2008). Recent investigations of the Gault site in Bell County, Texas, have raised the possibility that a pre-Clovis culture has been present in North America by at least 16,000 years ago (Williams et al. 2018).

The earliest generalized evidence for human activities in Central Texas is represented by the Paleolndian period (16,000 to 5000 B.P.) (Collins 1995; Rodrigues et al 2016; Williams et al. 2018). This stage coincided with ameliorating climatic conditions following the close of the Pleistocene epoch that witnessed the extinction of herds of mammoth, horse, camel, and bison. Cultures representing various periods within this stage are characterized by series of distinctive, relatively large, often fluted, lanceolate projectile points. These points are frequently associated with spurred end scrapers, gravers, and bone foreshafts. Paleolndian groups are often inferred to have been organized into egalitarian bands consisting of a few dozen individuals that practiced a fully nomadic subsistence and settlement pattern. Due to poor preservation of floral materials, subsistence patterns in Central Texas are known primarily through the study of faunal remains. Subsistence focused on the exploitation of plants, small animals, fish, and shellfish, even during the Paleolndian period. There is little evidence in this region for hunting of extinct megafauna, as has been documented elsewhere in North America. Rather, a broad-based subsistence pattern appears to have been practiced throughout all prehistoric time periods. In Central Texas, the Paleolndian stage is divided into two periods based on recognizable differences in projectile point styles. These include the Early Paleolndian period, which is recognized based on large, fluted projectile points (i.e., Clovis, Folsom, Dalton, San Patrice, and Big Sandy), and the Late 
Paleolndian period, which is characterized by unfluted lanceolate points (i.e., Plainview, Scottsbluff, Meserve, and Angostura).

\subsection{Archaic Period (CA. 8500 to 1200 B.P.)}

The onset of the Hypsithermal drying trend marks the beginning of the Archaic period (8500 to 1200 B.P.) (Collins 1995). This climatic trend marked the beginning of a significant reorientation of lifestyle throughout most of North America, but this change was far less pronounced in Central Texas. Elsewhere, the changing climatic conditions and corresponding decrease in the big game populations forced people to rely more heavily upon a diversified resource base composed of smaller game and wild plants. In Central Texas, however, this hunting and gathering pattern is characteristic of most of prehistory. The appearance of a more diversified tool kit, the development of an expanded groundstone assemblage, and a general decrease in the size of projectile points are hallmarks of this cultural stage. Material culture shows greater diversity during this broad cultural period, especially in the application of groundstone technology.

Traditionally, the Archaic period is subdivided into Early, Middle, and Late subperiods. Changes in projectile point morphology are often used as markers differentiating these three subperiods, though other changes in material culture occurred as well. Perhaps most markedly, burned rock middens appear during the Middle Archaic subperiod, continuing into the Late Archaic subperiod, and large cemeteries appear during the Late Archaic subperiod. In addition, the increasing density of prehistoric sites through time is often considered to constitute evidence of population growth, though differential preservation probably at least partially accounts for the lower numbers of older sites.

\subsection{Late Prehistoric Period (CA. 1200 to 350 B.P.)}

The onset of the Late Prehistoric period (1200 to 350 B.P.) (Collins 1995) is defined by the appearance of the bow and arrow. In Central Texas, pottery also appears during the Late Prehistoric period (though ceramics appear earlier in Southeast Texas). Use of the atlatl (i.e., spearthrower) and spear was generally discontinued during the Late Prehistoric period, though they continued to be used in the inland subregion of Southeast Texas along with the bow and arrow through the Late Prehistoric period (Patterson 1980, 1995; Wheat 1953). In Texas, unifacial arrow points appear to be associated with a small prismatic blade technology. The Late Prehistoric period is generally divided into two phases, the Austin and Toyah phases. Austin phase sites occur earliest to the north, which has led some researchers (e.g., Prewitt 1985) to suggest that the Austin-phase populations of Central Texas were migrants from the north and lack the ceramic industry of the later Toyah phase.

\subsection{Historic Period (CA. 350 B.P. to PResent)}

The first European incursion into what is now known as Texas was in 1519, when Álvarez de Pineda explored the northern shores of the Gulf of Mexico. In 1528, Cabeza de Vaca crossed South Texas after being shipwrecked along the Texas Coast near Galveston Bay. However, European settlement did not seriously disrupt native ways of life until after 1700 . The first half of 
Intensive Cultural Resources Survey of Proposed Dripping Springs

Wastewater System Improvements Project (EID 1), Dripping Springs, Hays County, Texas

the 18th century was the period in which the fur trade and mission system, as well as the first effects of epidemic diseases, began to seriously disrupt the native culture and social systems. This process is clearly discernable at the Mitchell Ridge site, where burial data suggest population declines and group mergers (Ricklis 1994) as well as increased participation on the part of the Native American population in the fur trade. By the time that heavy settlement of Texas began in the early 1800 s by Anglo-Americans, the indigenous Indian population was greatly diminished.

Before the first Spanish explorations of the area, several Native American cultures occupied the Edwards Plateau and the area now known as Hays County. This included the distinct archeological manifestation known as the Toyah Phase as well as the descendants of the Coahuiltecan-speakers, the Payaya, Tonkawa, and Jumano (which included sub-groups Cibolo, Hape, Mescale, Cholome, Cantona, Catqueza, and Caynaya) (Wade 2003). Post-Europeancontact tribes included the Lipan Apache, Kiowa-Apache, Wichita, and Comanche (Newcomb 1961; Wade 2003). Lesser-known groups and "micro-social coalitions" included the Ape, Arame, Bagname, Bobole, Ervipiame, Geniocane, Gueiquesale, Jumee, Mabibit, Manos Priestas, Natage, Ocane, Pataguache, Pinanaca, Siano, Teaname, Teroodan, Ypandi, Xaesar, and Xoman, all of which appeared in the Spanish records beginning in the mid-18th century (Wade 2003).

The Tonkawa Indians, whose tribal name is a Waco word, tonkaweya, which means "they all stay together," were historically tied to Central Texas as early as the late 17th century (Jones 1969:65; Newcomb 1961:134). Their linguistic family was thought to be affiliated with Karankawa, Comecrudo, and Cotoname, all a part of the Coahuiltecan stock (Swanton 1915, 1940); however, the former three languages are extinct, resulting in difficulties in establishing any relationships to Tonkawan (Jones 1969). The Tonkawa may have been an amalgamation of several independent bands, including the Tonkawas proper, the Mayeyes, the Cava, the Cantona, the Emet, the Sana, the Toho, and the Tohaha Indians (Carlisle 2010).

Led by Friar Nicolas Lopez and Juan Dominguez de Mendoza, the Mendoza-Lopez Expedition of 1684 was sent by the Spanish Crown to explore the unchartered "Kingdom of Tejas" and to document the encroaching French presence from the East (Wade 2003). As the entrada made their way eastward through the Edwards Plateau, they came across the present-day San Marcos Springs on January 28. There, the Spanish expedition camped for several days and killed 31 bison bulls, celebrated Mass, and named the river in honor of Saint Mark (Wade 2003). Several years later, in 1691, Governor Domingo Teran de los Rios and his expedition came through the area now known as San Marcos. Near the San Marcos River, de los Rios encountered several thousand Native Americans mostly from West Texas (the Cibola and Catqueza) and north-central Mexico parading with banners with images Our Lady of Guadalupe and carrying a "large, well-preserved wooden cross" (Foster 2008:185). As New Spain expanded the boundaries of its frontier north past the Rio Grande, the viceroy in Mexico City had sent the Aguirre expedition to pursue lands upon which to build future mission and presidio complexes (Chipman 1992). This was part of a continuing effort to convert the Tejas indios (Chipman 1992). In April 1701, Fathers Olivares and Espinosa traveled with the Aguirre entrada to the area of present-day Hays County, where they were explored the San Marcos and Blanco rivers as well as Onion Creek (Chipman 1992). In 1727, Brigadier General Pedro de Rivera y Villalon 
encountered several bison on the San Marcos and Blanco rivers (Wade 2003). It was a common occurrence for several bands of Native Americans to travel upwards to 643.7 kilometers (400.0 miles) from West Texas and northern Mexico to hunt bison on the Southern Plains in central Texas during the height of the "Little Ice Age" from A.D. 1400 to 1700 (Foster 2008).

El Camino Real, also known as El Camino Real de los Tejas and later as the Old San Antonio Road, passed through Hays County and linked the mission systems of northeastern Texas and western Louisiana with the Spanish frontier in northern Mexico and southward to Mexico City. This dendritic system of roads was the most important channel of immigration, commerce, communication, and supplies for the Spanish presidio-mission complexes and provincial government centers in Tejas. Officially established by the Teran de los Rios entrada in 1691 , it is likely that the Spanish used preexisting indigenous trading routes that linked Caddoan people to Coahuiltecans and Jumanos (Chipman 1992; Foster 2008; Wade 2003).

The first attempts at Spanish colonization in the area of present-day Hays County began in late 1755, when Capitan Rabago, under the orders of Governor Barrio, removed the San Xavier Mission and San Francisco Xavier Presidio from the confluence of the San Gabriel River and Brushy Creek to a more favorable site on the San Marcos River (Chipman 1992; Wade 2003). The decision to relocate may have been made to provide closer military protection for the Los Almagres Ore Mine in San Saba (Wade 2003). This move was short-lived, however, and the San Xavier presidio-mission complex was removed to San Antonio in 1756 (Chipman 1992). Despite this relocation, Capitan Parrilla, en route to the Los Almagras mine, moved nine Tlaxcaltecan families, cattle, supplies, and troops to San Marcos from March to May 1757, though it is unconfirmed where exactly they settled or what accommodations they utilized (Wade 2003). Hays County generally laid dormant from European excursions until the Spanish settlement San Marcos de Neve was founded from 1808 to 1812. It was positioned at the junction of the Camino Real and the San Marcos River, and 82 persons, mostly born in New Spain, practiced agriculture and livestock husbandry until the villa was eventually abandoned due to Comanche, Tonkawa, and Tawakoni attacks, floods, and crop failures (Folsom 2010).

After the Mexican War for Independence, several empresarios, or land grants, were issued to capitalists Juan Martin Veramendi, Juan Vicente Campos, and Thomas Jefferson Chambers in an attempt to populate the area (Cecil and Greene 2010). The Mexican government operating from the Departments of Coahuila and Texas issued a league of land to Thomas G. McGehee, the first Anglo-American to settle what is present-day Hays County, in 1835 (Cecil and Green 2010). In March of 1848, the nascent Texas Congress carved Hays County, named in honor of John Coffee Hays' Texas Rangers company, was carved from the territory south of Travis County. By 1850, San Marcos was chosen as the county seat. From 1850 to 1860, the county's population grew from a mere 387 to 2,126 as more Anglo-Americans settled the area. In 1849, General Edward Burleson dammed the San Marcos Springs to generate power for his saw and grist mills, which resulted in the formation of San Marcos Springs Lake. Hays County's first cotton gin was built by W.A. Thompson in the early 1850s, and, soon after, Ezekiel Nance, utilizing slave labor, built a dam on the Blanco River to power his sawmill, gristmill, and cotton gin (Nance 2010). The first Methodist church congregation was organized by Alfred B.F. Kerr in San Marcos in 1847, 
Intensive Cultural Resources Survey of Proposed Dripping Springs

Wastewater System Improvements Project (EID 1), Dripping Springs, Hays County, Texas

and the first schools were established between the years 1849 and 1852 (Cecil and Greene 2010; Williamson 2010).

Many of the first Anglo-American settlers in Hays County were from Arkansas, Georgia, and the Deep South; as such, the majority of the county's eligible voters $(n=166)$ voted in favor of secession from the Union in February 1861 (Timmons 1973). Several citizens from the county volunteered for the Confederate Army, including Colonel Peter C. Wood's Thirty-sixth Texas Calvary and Company A (Cecil and Greene 2010). The post-war Reconstruction period in Hays County saw an economic spur resulting from the cattle drive industry as well as the intensification of agriculture that was practiced in the more arable Blackland prairies found in the eastern half of the county. The population boomed from 4,088 in 1870 to 14,142 in 1900 as more settlers saw opportunities afforded by institutions of education, such as the Coronal Institute founded in 1866 and the Southwest Texas Normal School chartered in 1903. Also adding to the prosperity was the Hays County rail line funded by the International-Great Northern Railroad, which connected San Marcos to Austin and, later, to San Antonio (Cecil and Greene 2010). By World War I, Hays County was predominantly dependent upon an agricultural economy, and the population remained relatively stagnant until the opening of the Gary Job Corps Training Center in 1964 and an enrollment boom at Southwest Texas University when it officially switched from a teacher's college in 1969. By 1970 , the population of the county was 27,642 .

Today, San Marcos is home to several endangered species including the Texas Blind Salamander, the fountain darter, and the San Marcos gambusia. A rare species of aquatic rice, the Texas wild-rice, only grows within a 0.8-kilometer (0.5-mile) radius of San Marcos Springs. Perched on top the Edwards Aquifer discharge zone, the city sits above a system of unique limestone caves, including Wonder World Cave, Ezell Cave, and enormous aquatic caves full of unique fauna such as the blind albino catfish. Camp Ben McCulloch, positioned on Onion Creek near Driftwood, was organized in 1896 to serve as a Confederate soldier reunion camp; today, it hosts several festivals, such as Old Settlers Music Festival. As of 2018, Hays County has a population of 222,631 , and $24 \%$ of its citizens have a bachelor's degree. Whites dominate the ethnic makeup of the county at $88 \%$, African-Americans at $4 \%$, and Asians at $1 \%$. Texas State University is a large provider of jobs, and in 2018 the school had 38,666 students enrolled. 



\subsection{ARCHIVAL RESEARCH}

Prior to initiating fieldwork, Horizon personnel reviewed the THC's Texas Archeological Sites Atlas (TASA) online database for information on previously recorded archeological sites and previous archeological investigations conducted within a 1.6-kilometer (1.0-mile) radius of the project area (THC 2019). Based on this archival research, four previously recorded archeological sites (41HY198, 41HY203, 41HY424 and 41HY434), two cemeteries (the Philips Cemetery and an unnamed cemetery), and one National Register Historic District (NRHD) (the Dripping Springs Downtown Historic District) are located within a 1.6-kilometer (1.0-mile) radius of the project area (Figure 11; Table 2) (THC 2019).

Previously recorded archeological sites 41HY198, 41HY203, and 41HY434 consist of aboriginal campsites and lithic scatters related primarily to lithic raw material procurement activities. Site $41 \mathrm{HY} 198$ also has a historic-age component that consists of a scatter of glass shards, ceramic sherds, and metal hardware dating to late 19th to early 20th centuries. Site $41 \mathrm{HY} 424$, also known as the B.M. Gibson Homestead, dates from the 1870s to the mid20th century, consists of a hand-dug well, a seep spring, a dilapidated log cabin with a chimney, stone walls, a stone and mortar fire box, a road remnant, and a wire fence enclosing the entire farmstead. The site was designated as an SAL in 2006.

Located a short distance southwest of the Water Reclamation Line segment of the project area is the Philips Cemetery. A Methodist Episcopal Church constructed on the adjacent tract in 1880 (Phillips Cemetery 2019). In 1901, the church building was relocated and the land was used solely as a Methodist cemetery (phillipscemetery.com 2019). The historic-age debris reported on site 41HY198 may be affiliated with the Methodist church that once stood on the property. To the northeast of the project area is an unnamed cemetery within the city of Dripping Springs and the Dripping Springs Downtown Historic District. The cemetery near the center of Dripping Springs appears on US Geological Survey (USGS) topographic maps dating from the mid- to late 20th century; however, it does not appear on maps after 2012 (NETR 2020) or on modern imagery, which suggests that the cemetery may have been removed at some point during the expansion of Dripping Springs. The Dripping Springs Downtown Historic District dates to the late 19th to mid-20th centuries and consists of agricultural, commercial, and residential resources along Mercer Street (THC 2019). 
SENSITIVE ARCHEOLOGICAL SITE LOCATION INFORMATIONOMITTED

Figure 11. Known Cultural Resources within 1.0 Mile of Project Area 
Table 2. Summary of Cultural Resources within 1.0 Mile of Project Area

\begin{tabular}{|c|c|c|c|c|}
\hline $\begin{array}{c}\text { Site } \\
\text { No./Name }\end{array}$ & Site Type & $\begin{array}{l}\text { NRHP/SAL } \\
\text { Eligibility } \\
\text { Status }^{1}\end{array}$ & $\begin{array}{l}\text { Distance/Direction } \\
\text { from Project Area }\end{array}$ & $\begin{array}{l}\text { Potential to } \\
\text { be Impacted } \\
\text { by Project? }\end{array}$ \\
\hline \multicolumn{5}{|c|}{ Archeological Sites } \\
\hline 41HY198 & $\begin{array}{l}\text { Aboriginal lithic scatter } \\
\text { (undetermined prehistoric); } \\
\text { Historic-age artifact scatter } \\
\text { (late 19th to early 20th } \\
\text { centuries) }\end{array}$ & Undetermined & $\begin{array}{c}0.1 \text { mile southwest } \\
\text { of Water } \\
\text { Reclamation Line }\end{array}$ & No \\
\hline 41HY203 & $\begin{array}{l}\text { Aboriginal campsite } \\
\text { (undetermined prehistoric) }\end{array}$ & Undetermined & $\begin{array}{l}0.2 \text { mile southeast of } \\
\text { West Interceptor; } \\
0.1 \text { mile southwest } \\
\text { of Water } \\
\text { Reclamation Line }\end{array}$ & No \\
\hline 41HY424 & $\begin{array}{l}\text { Historic-age farmstead } \\
\text { (B.M. Gibson Homestead) } \\
\text { (built ca. 1870s) }\end{array}$ & $\begin{array}{l}\text { NRHP-eligible/ } \\
\text { designated as } \\
\text { SAL }\end{array}$ & $\begin{array}{l}0.6 \text { mile southeast of } \\
\text { West Interceptor; } \\
0.4 \text { mile northwest of } \\
\text { effluent pond }\end{array}$ & No \\
\hline 41HY434 & $\begin{array}{l}\text { Aboriginal campsite } \\
\text { (undetermined prehistoric) }\end{array}$ & $\begin{array}{l}\text { Determined } \\
\text { ineligible }\end{array}$ & $\begin{array}{l}1.0 \text { mile southeast of } \\
\text { effluent pond }\end{array}$ & No \\
\hline \multicolumn{5}{|c|}{ Listed Historic Properties } \\
\hline $\begin{array}{l}\text { Dripping } \\
\text { Springs } \\
\text { Downtown } \\
\text { Historic District }\end{array}$ & $\begin{array}{l}\text { Historic commercial district } \\
\text { (ca. } 1872 \text { to } 1941 \text { ) }\end{array}$ & Listed on NRHP & $\begin{array}{l}0.8 \text { mile northeast of } \\
\text { West Interceptor }\end{array}$ & No \\
\hline \multicolumn{5}{|l|}{ Cemeteries } \\
\hline $\begin{array}{l}\text { Phillips } \\
\text { Cemetery } \\
\text { (HY-C029) }\end{array}$ & Cemetery & N/A & $\begin{array}{c}60.0 \text { feet southwest } \\
\text { of Water } \\
\text { Reclamation Line }\end{array}$ & No \\
\hline $\begin{array}{l}\text { Unknown } \\
\text { (Dripping } \\
\text { Springs) } \\
\text { (HY-C032) }\end{array}$ & Cemetery & $\mathrm{N} / \mathrm{A}$ & $\begin{array}{l}1.0 \text { mile northeast of } \\
\text { West Interceptor }\end{array}$ & No \\
\hline
\end{tabular}

1 Determined eligible/ineligible = Site determined eligible/ineligible by SHPO

Recommended eligible/ineligible = Site recommended as eligible/ineligible by site recorder and/or sponsoring agency but eligibility has not been determined by SHPO

Undetermined = Eligibility not assessed or no information available

NRHP National Register of Historic Places

SAL State Antiquities Landmark

SHPO State Historic Preservation Office

Most of the known cultural resources are located well outside of the project area and would not be disturbed as a result of the proposed undertaking. The Phillips Cemetery is located in close proximity to the southeastern end of the proposed Water Reclamation Line segment of the project area; however, the proposed water line is located within the FM 12 ROW and shares an 
easement with an existing wastewater line, and there is no indication of unmarked graves this far north of the cemetery boundaries on modern aerial imagery (or noted during Horizon's cultural resources survey).

Sites 41HY198, 41HY203, 41HY424 and 41HY434 were recorded during archeological surveys conducted in advance of prior proposed sewer systems by the US EPA 1987 and by Horizon in 2005 and 2007 (Owens 2005, 2007). The West Interceptor segment of the project area has not been previously surveyed for cultural resources. Portions of the Reclaimed Water Line segment of the project area have been previously surveyed, including approximately half of the northwestern portion of the line as well as the entire portion of the line located within the FM 12 ROW. The proposed water reclamation facility and effluent pond fall within the area previously surveyed by Horizon in 2005 (Owens 2005).

Examination of historical USGS topographic maps dating from dating from 1962 to present and historical aerial photographs dating from 1965 to present indicates that no historic-age structures have been present within the project area since at least the mid-20th century (NETR 2019). 


\subsection{SURVEY METHODOLOGY}

From October 1 to 3, on November 4, and on November 22, 2019, Horizon archeologists Jesse Dalton, McKinzie Froese, Amy Goldstein, Elizabeth Sefton, and Jared Wiersema conducted an intensive cultural resources survey of the project area, including pedestrian walkover with shovel testing and backhoe trenching. The survey was performed under the supervision of Jeffrey D. Owens, who served as Principal Investigator, under Texas Antiquities Permit No. 9114. The purpose of the survey was to locate any significant cultural resources that potentially would be impacted by the proposed undertaking.

Horizon's archeologists traversed the project area on foot and thoroughly inspected the modern ground surface for aboriginal and historic-age cultural resources. Overall, vegetation across the entire project area generally consisted of short- to medium-length grasses interspersed with mature live oak and cedar trees, which afforded fair to good ground surface visibility (30 to $60 \%$ ). Within the riparian zone of Onion Creek, vegetation consisted of tall, dense grass and mature honey mesquite, cedar, live oak, and hackberry trees, which provided poor ground surface visibility $(<30 \%)$.

The West Interceptor segment runs along the gravelly terraces of Onion Creek (Figures 12 to 17). Topographically, this segment of the project area consists of steep limestone steps and rocky outcrops that give way to flat, open fields. The proposed interceptor crosses Onion Creek at three locations, and the lower stream terraces of the creek have extensive gravel bars and debris associated with high-energy flooding. Soil profiles typically consist of a shallow A horizon of hard, calcareous clay loam underlain by dense gravelly deposits; however, in the southeastern portion of the West Interceptor, deeper clayey loam alluvium underlain by limestone bedrock was encountered.

The Reclaimed Water Line segment traverses the west-facing hillslopes of upland ridges east of Onion Creek (Figures 18 to 20). Approximately the southeastern half of this segment of the project area would be constructed within the existing ROW of FM 12 west of the roadway, and construction, use, and ongoing maintenance of the roadway and associated facilities has resulted in extensive prior disturbances. Evidence of ground disturbance resulting from land clearing for housing developments and a transmission line were also noted within the northwestern portion of the proposed Reclaimed Water Line segment. The far northwestern end of the proposed Reclaimed Water Line segment skims the edge of the floodplain associated with a tributary of Onion Creek. Sediments on the terraces of this stream channel consist of calcareous 


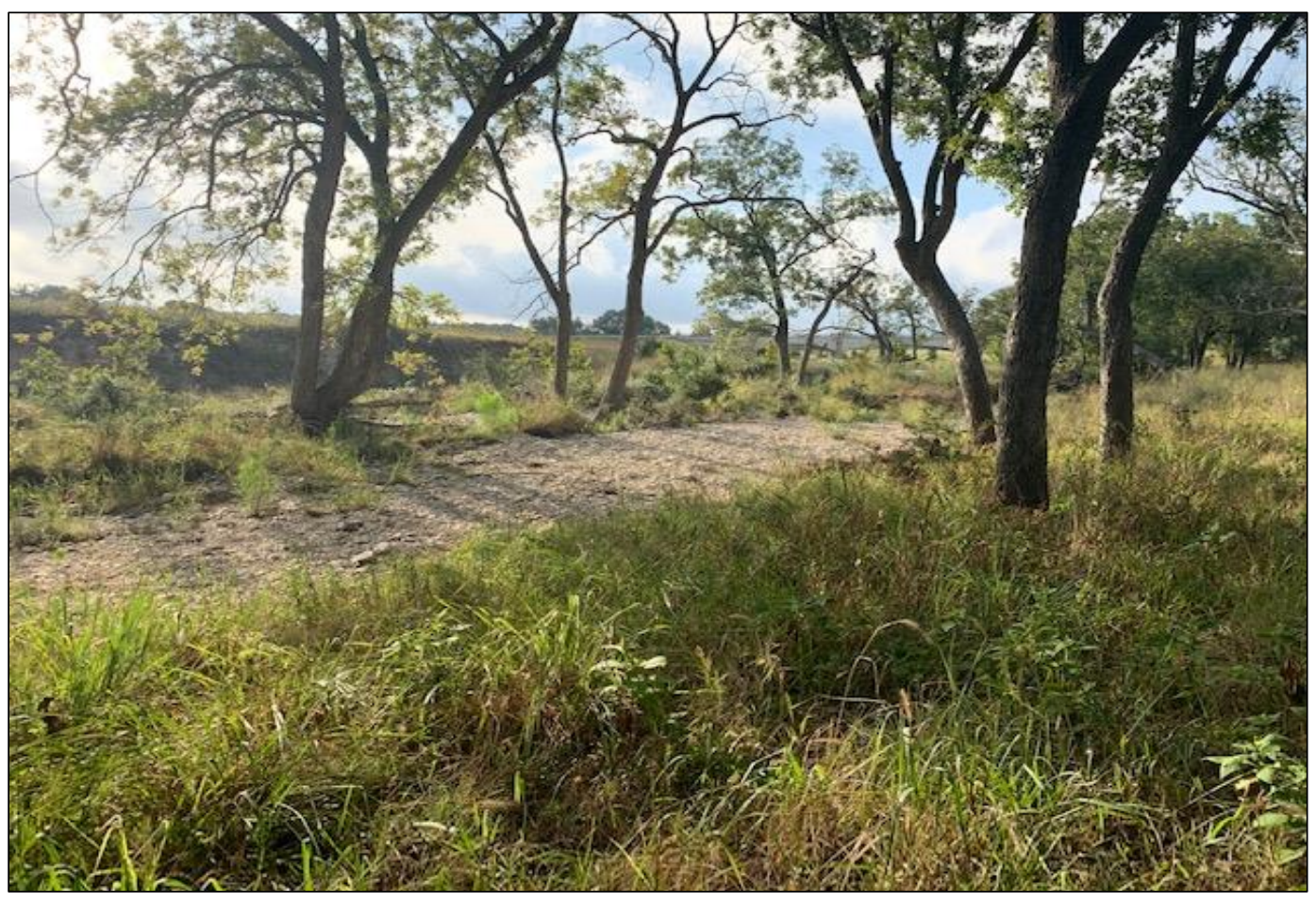

Figure 12. Southern End of West Interceptor (Facing Southeast)

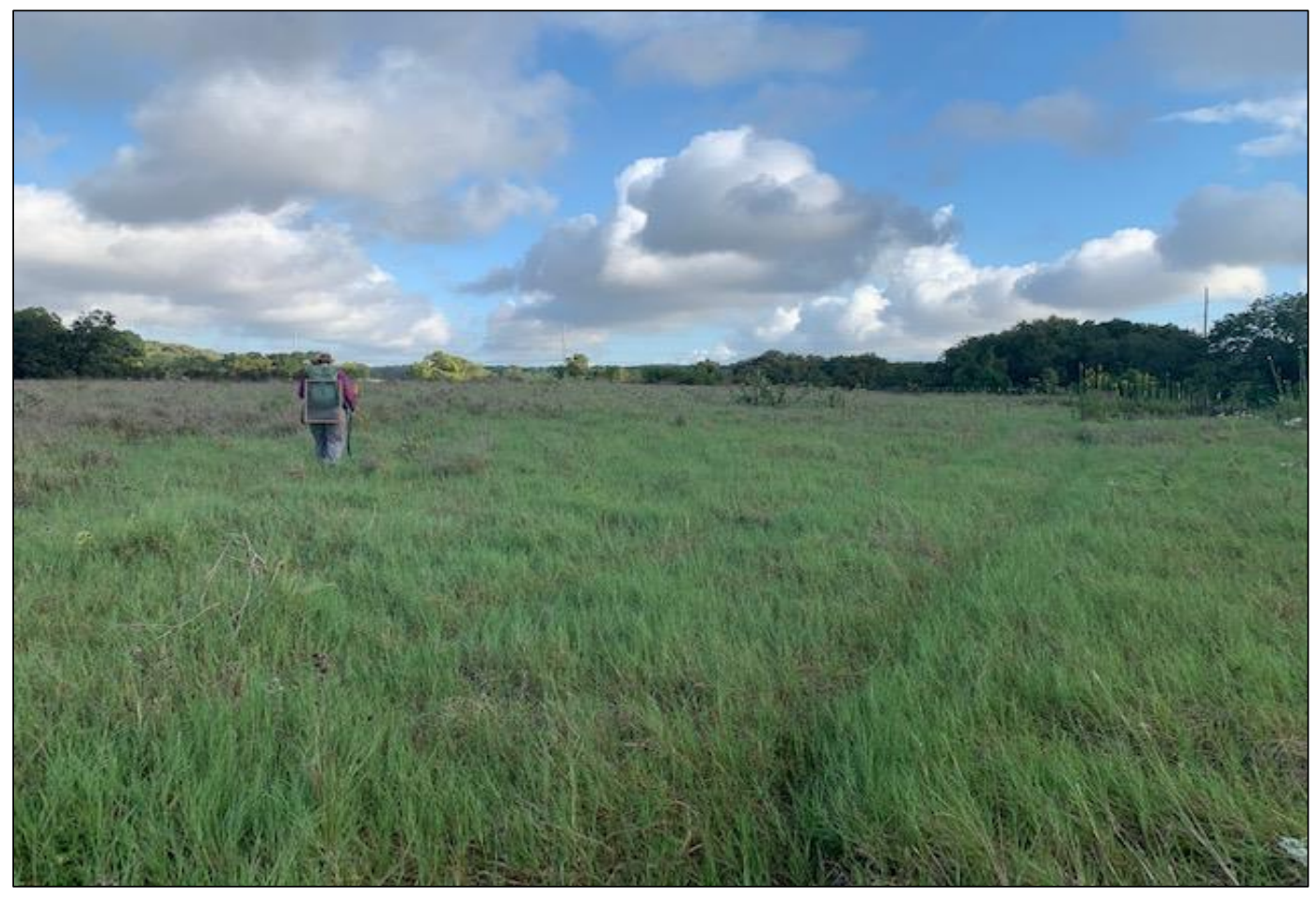

Figure 13. Upper Terrace in Southeastern Portion of West Interceptor (Facing North) 
Intensive Cultural Resources Survey of Proposed Dripping Springs

Wastewater System Improvements Project (EID 1), Dripping Springs, Hays County, Texas

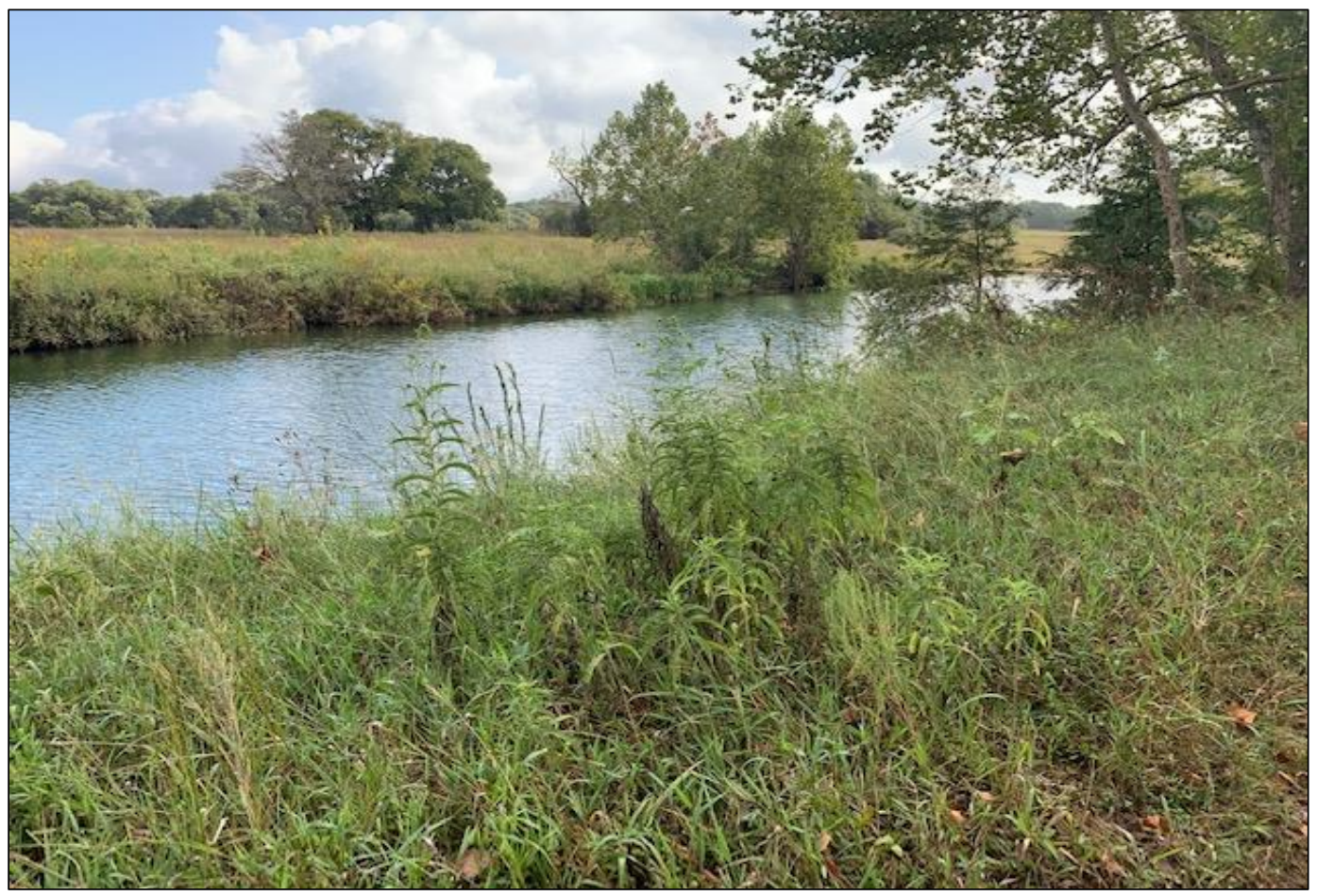

Figure 14. Onion Creek in Central Portion of West Interceptor (Facing Northeast)

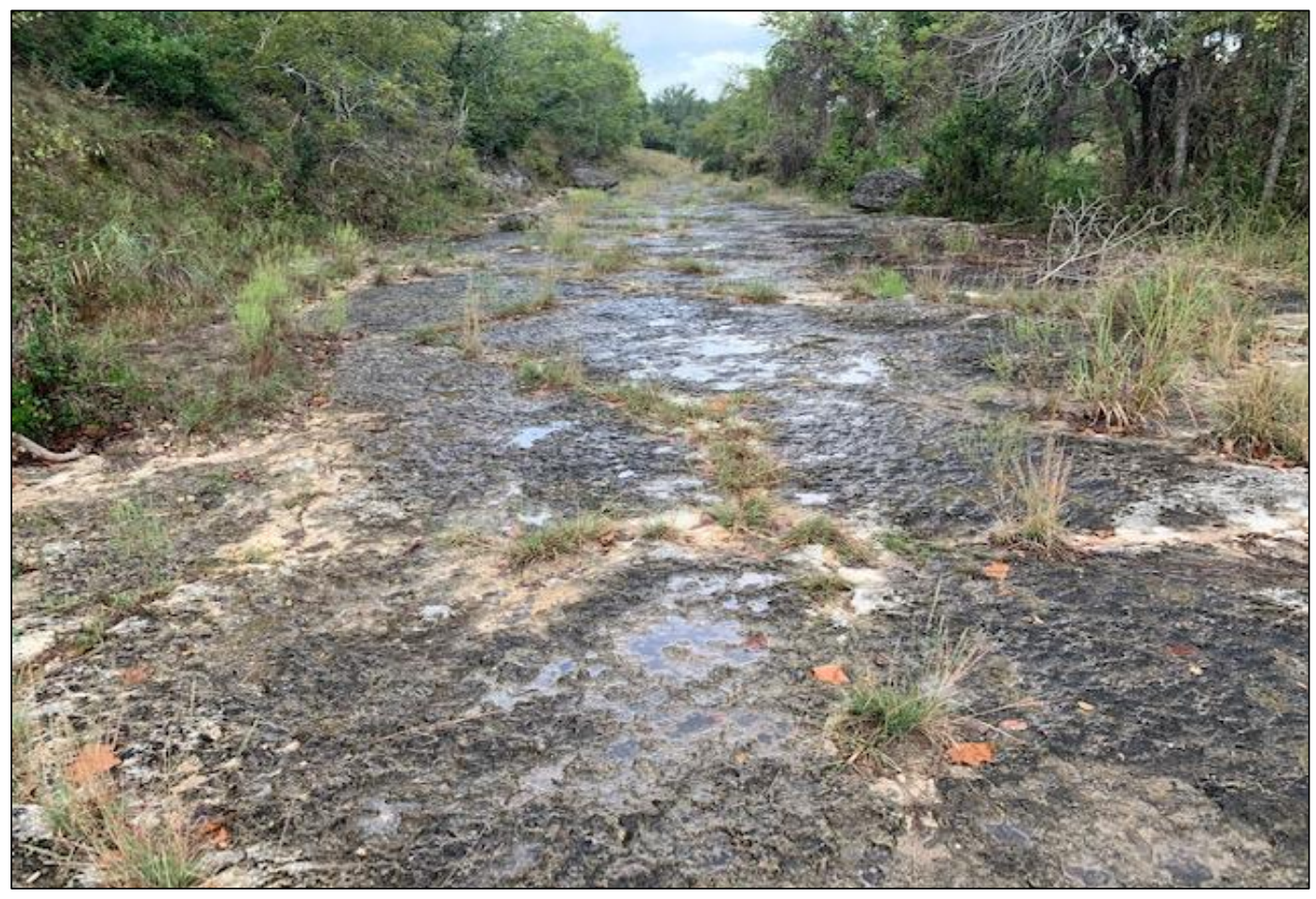

Figure 15. Limestone Step in Central Portion of West Interceptor (Facing North) 




Figure 16. Lower Terrace on West Interceptor Option A (Facing South)

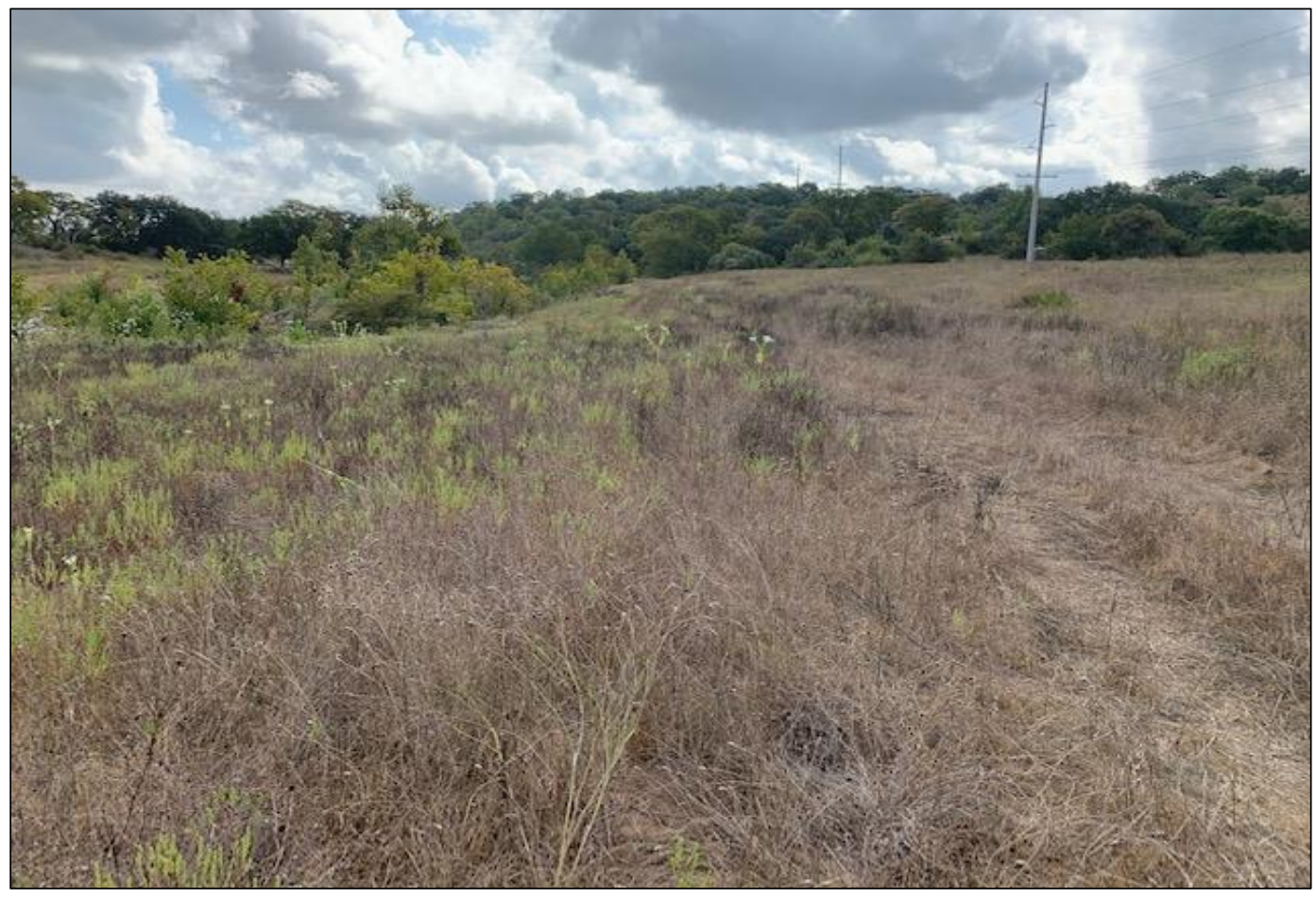

Figure 17. Lower Terrace on West Interceptor Option B (Facing Southeast) 
Intensive Cultural Resources Survey of Proposed Dripping Springs

Wastewater System Improvements Project (EID 1), Dripping Springs, Hays County, Texas

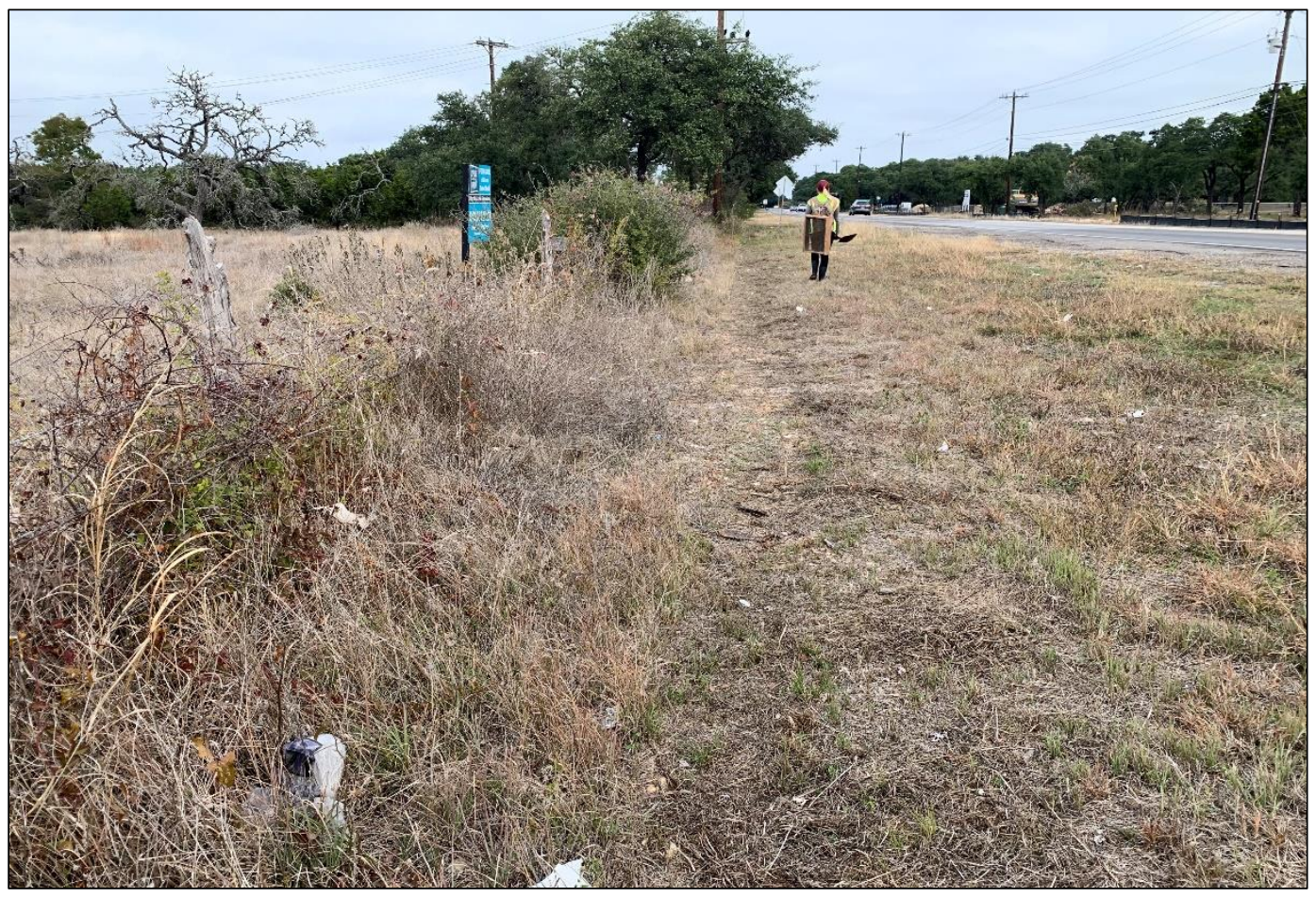

Figure 18. Eastern Portion of Reclaimed Water Line Paralleling FM 12 (Facing North)

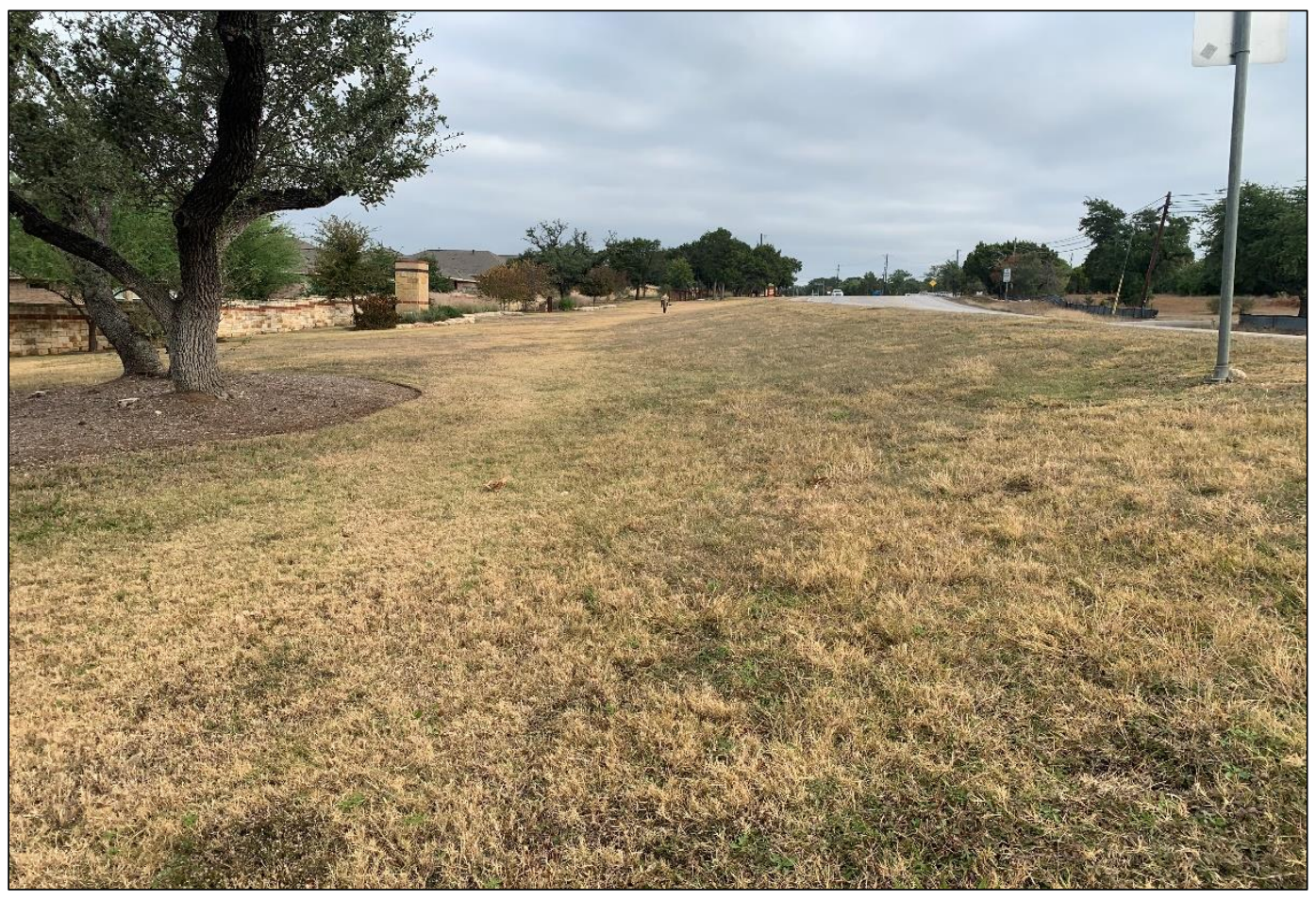

Figure 19. Eastern Portion of Reclaimed Water Line Paralleling FM 12 (Facing North) 


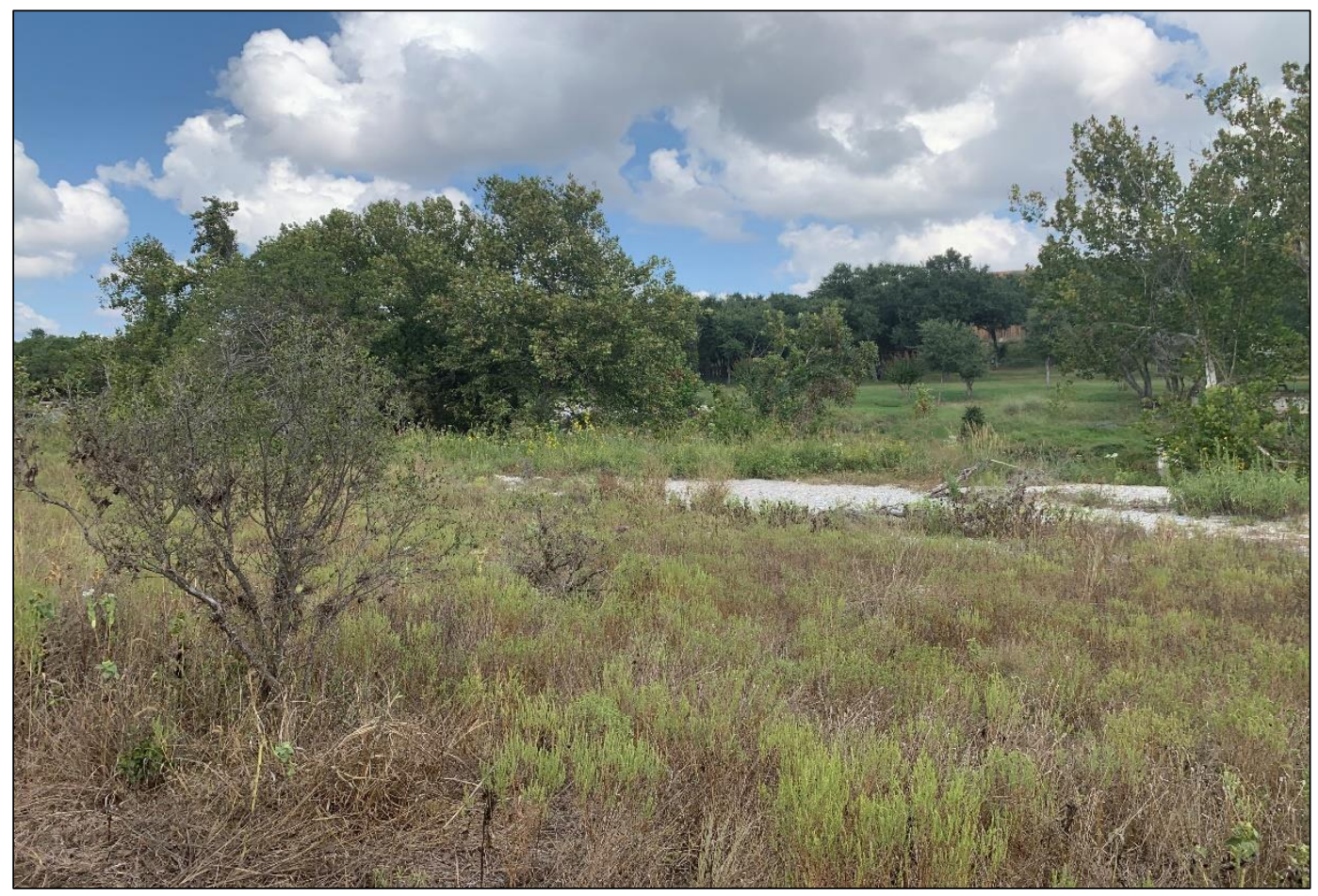

Figure 20. Western End of Reclaimed Water Line (Facing North)

loamy alluvial deposits, while soils across the upland portions of the segment consist of shallow deposits of gravelly clay and clay loam underlain by naturally degrading limestone bedrock.

The water reclamation facility expansion and effluent pond segment are located on the upper terraces northeast of Onion Creek (Figures 21 to 22). The water reclamation facility is an existing industrial facility surrounded by septic fields, and prior disturbances from construction, use, and ongoing maintenance of the facility are extensive. The proposed expansion area to the north of the existing facility is currently utilized as a septic field. Sediments within this segment of the project area consist of shallow, gravelly, calcareous loamy to clayey loam alluvium underlain by naturally degrading limestone bedrock.

In addition to a pedestrian walkover, the Texas State Minimum Archeological Survey Standards (TSMASS) require a minimum of 16 subsurface shovel tests per 1.6 kilometers (1.0 mile) for each 30.5-meter- (100.0-foot-) wide transect (or fraction thereof) for linear surveys unless field conditions warrant more shovel tests (e.g., in cultural high-probability areas) or fewer shovel tests (e.g., on steep slopes, in areas with excellent ground surface visibility). For blockarea surveys, the TSMASS require two shovel tests per 0.4 hectare $(1.0$ acre) for project areas between 1.2 and 4.0 hectares (3.0 and 10.0 acres) in size. As such, a minimum of 37 shovel tests would be required within the West Interceptor segment, 13 shovel tests would be required within the Reclaimed Water Line segment, and 16 shovel tests would be required within the proposed water reclamation facility expansion and effluent pond area, for a total of 66 shovel tests 


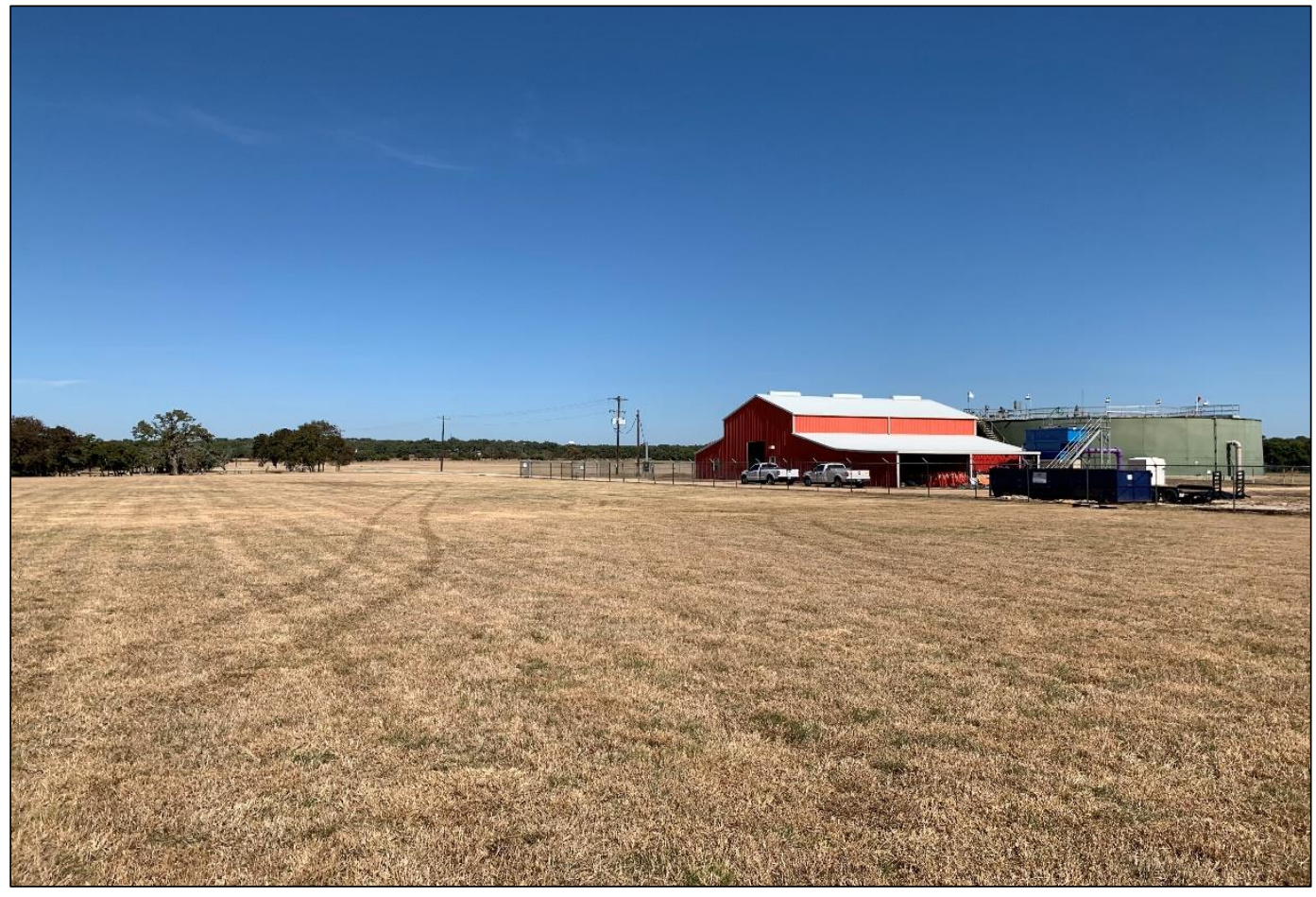

Figure 21. Existing Water Reclamation Facility Expansion Area (Note Existing Reclamation Facility at Right) (Facing North-Northeast)

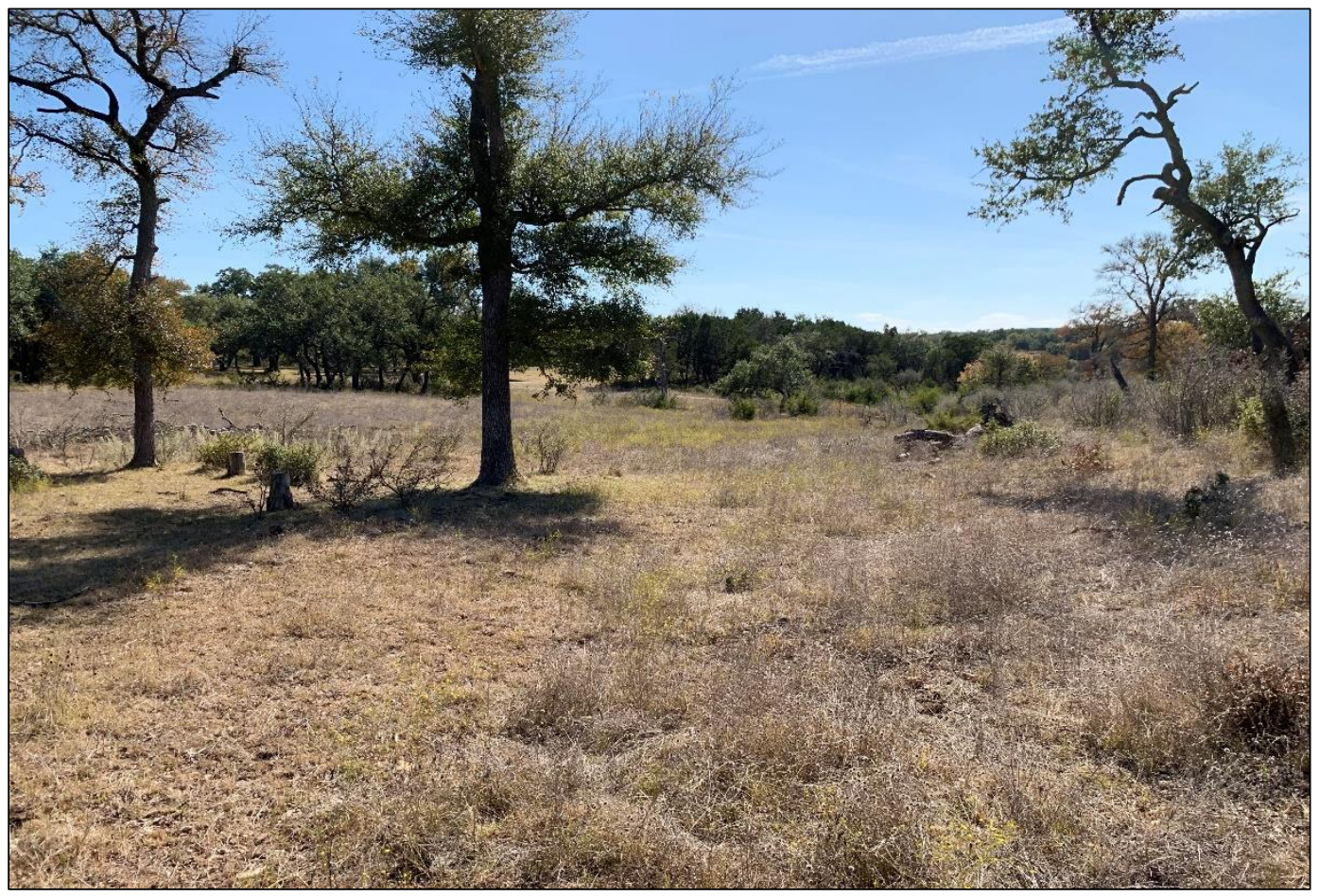

Figure 22. Proposed Effluent Pond Area (Facing Southeast) 
for the project area as a whole. Horizon excavated a total of 106 shovel tests during the survey, including 82 shovel tests within the West Interceptor segment, 13 shovel tests within the Reclaimed Water Line segment, and 11 shovel tests within the facility expansion and effluent pond area (Figures 23 to 25). The shovel tests within the proposed facility expansion and effluent pond area were not all excavated directly within the final proposed construction footprint as the boundaries of this portion of the project area had not been firmly determined at the time of the survey, and no shovel tests were excavated within the existing water reclamation facility due to the extent of observable prior disturbances within this area. Overall, Horizon exceeded the minimum number of shovel tests required for the project area as a whole, and it is Horizon's opinion that shovel testing was capable of fully penetrating sediments with the potential to contain subsurface archeological deposits (with the exception noted below where backhoe trenches were excavated along a portion of the West Interceptor segment).

Shovel tests generally measured 30.0 centimeters (11.8 inches) in diameter and were excavated to a target depth of 1.0 meter (3.3 feet) below surface, to the top of pre-Holocene deposits, or to the maximum depth practicable. In practice, shovel tests were terminated at depths ranging from 5.0 to 85.0 centimeters (2.0 to 33.5 inches) below surface, though typically in the range of 30.0 to 45.0 centimeters (11.8 to 17.7 inches) below surface, due to the presence of dense limestone gravels, limestone bedrock, or dense river gravel deposits. All sediments were screened through 6.35-millimeter $(\mathrm{mm})$ (0.25-inch) hardware cloth. Standard shovel test logs were completed for each shovel test describing the location, strata, soil texture and color, archeological materials (if present), and any unusual characteristics of the surrounding landscape.

All sediments excavated from shovel tests were replaced in the shovel test hole upon completion of recording. The Universal Transverse Mercator (UTM) coordinates of each shovel test were determined using Collector for ArcGIS data collection software using the North American Datum of 1983 (NAD 83). Specific shovel test data are summarized in Appendix A.

In addition to shovel testing, Horizon excavated four backhoe trenches within the southeastern portion of the proposed West Interceptor segment (Figure 26). The trenches were excavated at roughly 100.0-meter (328.0-foot) intervals along the proposed centerline to depths ranging from 105.0 to 350.0 centimeters (41.3 to 137.8 inches) below surface. Trenches measured 5.5 meters (18.0 feet) in length and were excavated with a 0.6-meter- (2.0-foot-) wide bucket equipped with a flat-edged clean-out bar. During trench excavations, soil "lifts" (i.e., thin, subhorizontal layers) measuring approximately 10.0 centimeters (3.9 inches) in thickness were removed from across the entire trench, and the emerging trench walls and floor were thoroughly inspected for evidence of artifacts, cultural features, or anomalous soil horizons that may suggest the presence of buried land horizons potentially associated with prehistoric cultural occupations. A sample of backfill removed from each trench was screened through 6.35-millimeter (0.25-inch) hardware cloth during trench excavation. A minimum of one 5.0-gallon bucket from every third backhoe bucket load was screened, though additional backfill from selected soil horizons was screened if the potential for subsurface archeological deposits was judged to be high. Following completion of each trench excavation, a 1.0-meter- (3.3-foot-) wide section of one trench wall was scraped down with a flat-bladed shovel to expose a clear stratigraphic profile for inspection and photography. A standard backhoe trenching form was completed for each trench detailing soil 
Intensive Cultural Resources Survey of Proposed Dripping Springs

Wastewater System Improvements Project (EID 1), Dripping Springs, Hays County, Texas

Map intensionally removed to protect cultural resource locations

Figure 23. Locations of Shovel Tests Excavated on West Interceptor (Option A and B) 


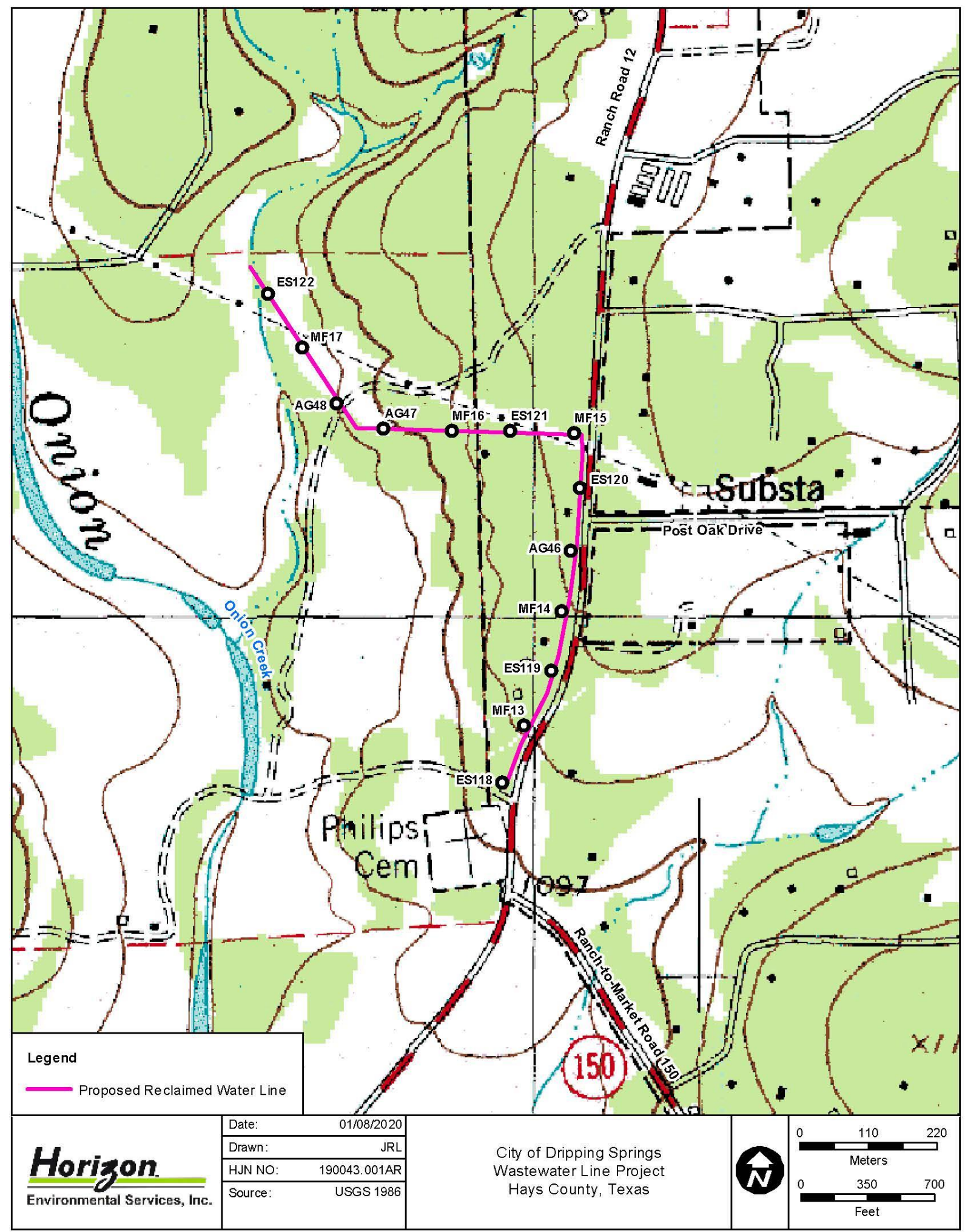

Figure 24. Locations of Shovel Tests Excavated on Reclaimed Water Line 


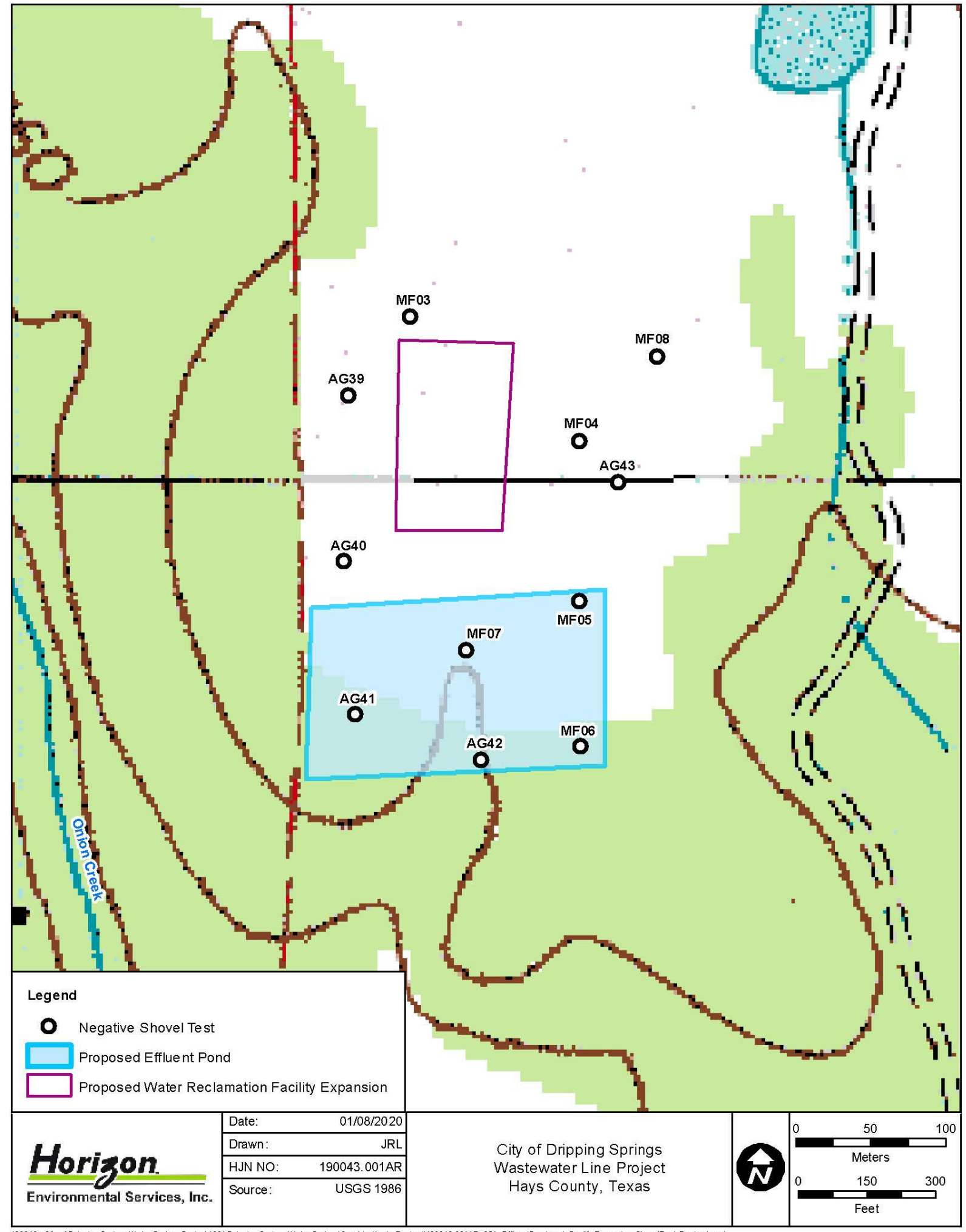

Figure 25. Locations of Shovel Tests on Reclamation Facility and Effluent Pond 
Map intensionally removed to protect cultural resource locations

Figure 26. Locations of Backhoe Trenches Excavated on West Interceptor 
characteristics, stratigraphy, and the presence or absence of cultural materials. Color digital photographs were taken of each trench and profile exposure. After recording was completed, each trench was immediately backfilled and the ground surface was restored as closely as possible to its original condition. At no time was an open trench left unattended. Specific shovel test data are presented in Appendix B.

During the survey, field notes were maintained on terrain, vegetation, soils, landforms, survey methods, and shovel test results. Digital photographs were taken, and a photographic log was maintained. Horizon employed a non-collection policy for cultural resources. Diagnostic artifacts (e.g., projectile points, ceramics, historic materials with maker's marks) and nondiagnostic artifacts (e.g., lithic debitage, burned rock, historic glass, and metal scrap) were described, sketched, and/or photo-documented in the field and replaced in the same location in which they were found. One chert secondary flake was recorded in a shovel test (ST AG30) at the far western end of the West Interceptor project segment. Supplemental delineation shovel tests excavated around this initial discovery failed to produce any additional evidence of prehistoric cultural activity at this location, so the chert flake was recorded as an isolated artifact occurrence but was not documented as an archeological site. No other cultural resources of prehistoric or historic age were recorded within the project area during the pedestrian survey, shovel testing, or backhoe trenching.

Following completion of the project, all project records will be prepared for permanent curation at the Texas Archeological Research Laboratory (TARL). The survey methods employed during the survey represented a "reasonable and good-faith effort" to locate significant archeological sites within the project area as defined in 36 CFR 800.3. 



\subsection{RESULTS OF INVESTIGATIONS}

From October 1 to 3, on November 4, and on November 22, 2019, Horizon archeologists Jesse Dalton, McKinzie Froese, Amy Goldstein, Elizabeth Sefton, and Jared Wiersema conducted an intensive cultural resources survey of the project area, including pedestrian walkover with shovel testing and backhoe trenching. The survey was performed under the supervision of Jeffrey D. Owens, who served as Principal Investigator, under Texas Antiquities Permit No. 9114. The purpose of the survey was to locate any significant cultural resources that potentially would be impacted by the proposed undertaking. Horizon's archeologists traversed the project area on foot and thoroughly inspected the modern ground surface for aboriginal and historic-age cultural resources.

Overall, vegetation across the entire project area generally consisted of short- to mediumlength grasses interspersed with mature live oak and cedar trees, which afforded fair to good ground surface visibility (30 to 60\%). Within the riparian zone of Onion Creek, vegetation consisted of tall, dense grass and mature honey mesquite, cedar, live oak, and hackberry trees, which provided poor ground surface visibility $(<30 \%)$.

The West Interceptor segment runs along the gravelly terraces of Onion Creek. Topographically, this segment of the project area consists of steep limestone steps and rocky outcrops that give way to flat, open fields. The proposed interceptor crosses Onion Creek at three locations, and the lower stream terraces of the creek have extensive gravel bars and debris associated with high-energy flooding. Soil profiles typically consist of a shallow A horizon of hard, calcareous clay loam underlain by dense gravelly deposits; however, in the southeastern portion of the West Interceptor, deeper clayey loam alluvium underlain by limestone bedrock was encountered.

The Reclaimed Water Line segment traverses the west-facing hillslopes of upland ridges east of Onion Creek. Approximately the southeastern half of this segment of the project area would be constructed within the existing ROW of FM 12 west of the roadway, and construction, use, and ongoing maintenance of the roadway and associated facilities has resulted in extensive prior disturbances. Evidence of ground disturbance resulting from land clearing for housing developments and a transmission line were also noted within the northwestern portion of the proposed Reclaimed Water Line segment. The far northwestern end of the proposed Reclaimed Water Line segment skims the edge of the floodplain associated with a tributary of Onion Creek. Sediments on the terraces of this stream channel consist of calcareous loamy alluvial deposits, 
while soils across the upland portions of the segment consist of shallow deposits of gravelly clay and clay loam underlain by naturally degrading limestone bedrock.

The water reclamation facility expansion and effluent pond segment are located on the upper terraces northeast of Onion Creek. The water reclamation facility is an existing industrial facility surrounded by septic fields, and prior disturbances from construction, use, and ongoing maintenance of the facility are extensive. The proposed expansion area to the north of the existing facility is currently utilized as a septic field. Sediments within this segment of the project area consist of shallow, gravelly, calcareous loamy to clayey loam alluvium underlain by naturally degrading limestone bedrock.

In addition to a pedestrian walkover, the TSMASS require a minimum of 16 subsurface shovel tests per 1.6 kilometers $(1.0$ mile) for each 30.5 -meter- (100.0-foot-) wide transect (or fraction thereof) for linear surveys unless field conditions warrant more shovel tests (e.g., in cultural high-probability areas) or fewer shovel tests (e.g., on steep slopes, in areas with excellent ground surface visibility). For block-area surveys, the TSMASS require two shovel tests per 0.4 hectare (1.0 acre) for project areas between 1.2 and 4.0 hectares (3.0 and 10.0 acres) in size. As such, a minimum of 37 shovel tests would be required within the West Interceptor segment, 13 shovel tests would be required within the Reclaimed Water Line segment, and 16 shovel tests would be required within the proposed water reclamation facility expansion and effluent pond area, for a total of 66 shovel tests for the project area as a whole. Horizon excavated a total of 106 shovel tests during the survey, including 82 shovel tests within the West Interceptor segment, 13 shovel tests within the Reclaimed Water Line segment, and 11 shovel tests within the facility expansion and effluent pond area. The shovel tests within the proposed facility expansion and effluent pond area were not all excavated directly within the final proposed construction footprint as the boundaries of this portion of the project area had not been firmly determined at the time of the survey, and no shovel tests were excavated within the existing water reclamation facility due to the extent of observable prior disturbances within this area. Overall, Horizon exceeded the minimum number of shovel tests required for the project area as a whole, and it is Horizon's opinion that shovel testing was capable of fully penetrating sediments with the potential to contain subsurface archeological deposits (with the exception noted below where backhoe trenches were excavated along a portion of the West Interceptor segment).

In addition to shovel testing, Horizon excavated four backhoe trenches within the southeastern portion of the proposed West Interceptor segment. The trenches were excavated at roughly 100.0 -meter (328.0-foot) intervals along the proposed centerline to depths ranging from 105.0 to 350.0 centimeters ( 41.3 to 137.8 inches) below surface. Sediments observed within trench profiles typically consisted of moderately deep deposits of grayish-brown fine clay loam over yellowish-brown fine sandy loam. Dense deposits of river cobbles and/or naturally degrading limestone bedrock were observed at the base of three of the four trenches, and it is Horizon's opinion that backhoe trenching was capable of fully penetrating sediments with the potential to contain archeological deposits.

One chert flake was recorded in a shovel test (ST AG30) at a depth of 0.0 to 30.0 centimeters ( 0.0 to 11.8 inches) below surface at the far northwestern end of the West Interceptor project segment (Figures 27 to 28). Supplemental delineation shovel tests excavated 
Intensive Cultural Resources Survey of Proposed Dripping Springs

Wastewater System Improvements Project (EID 1), Dripping Springs, Hays County, Texas

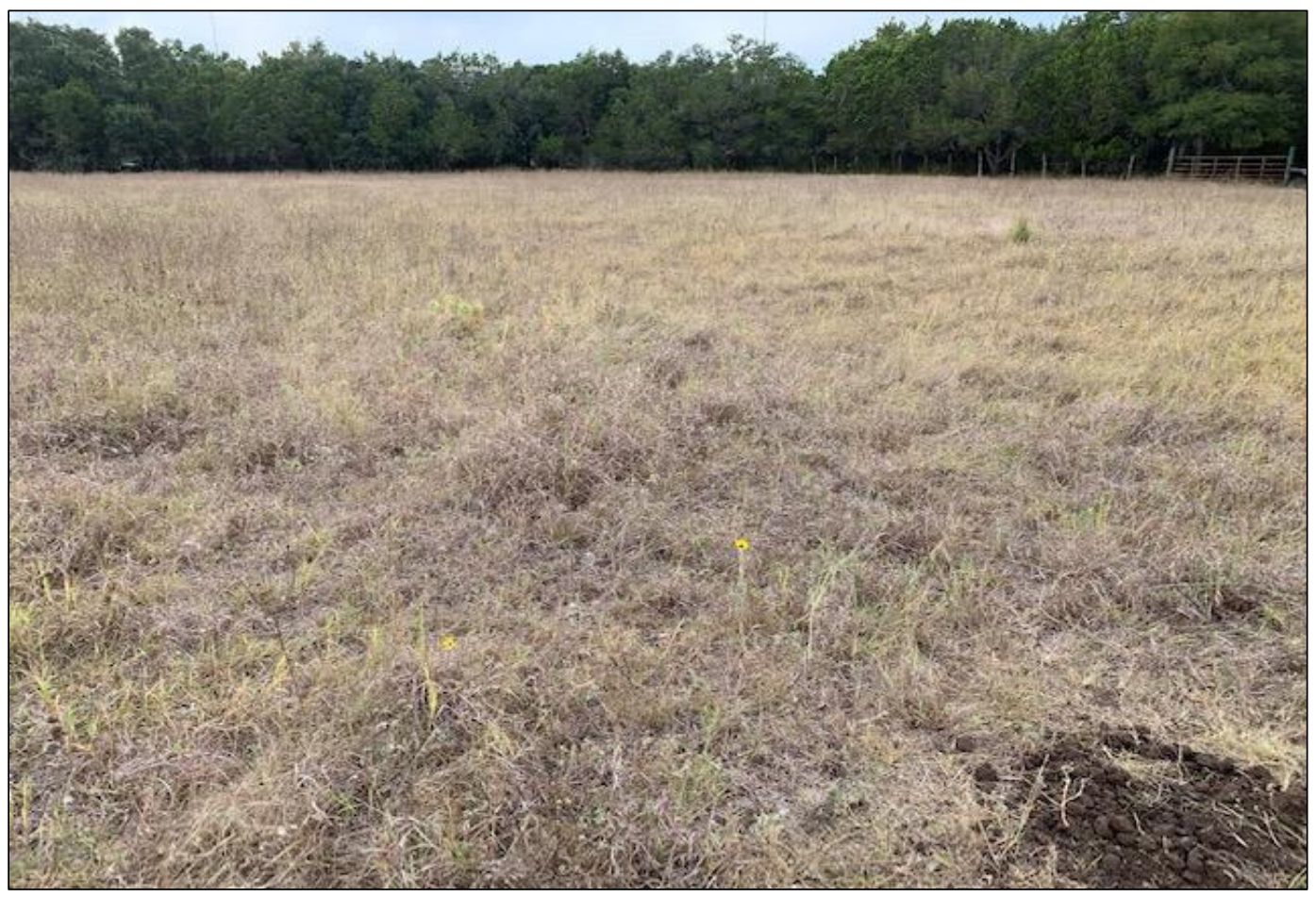

Figure 27. Location of Chert Flake Found on West Interceptor (Facing South)

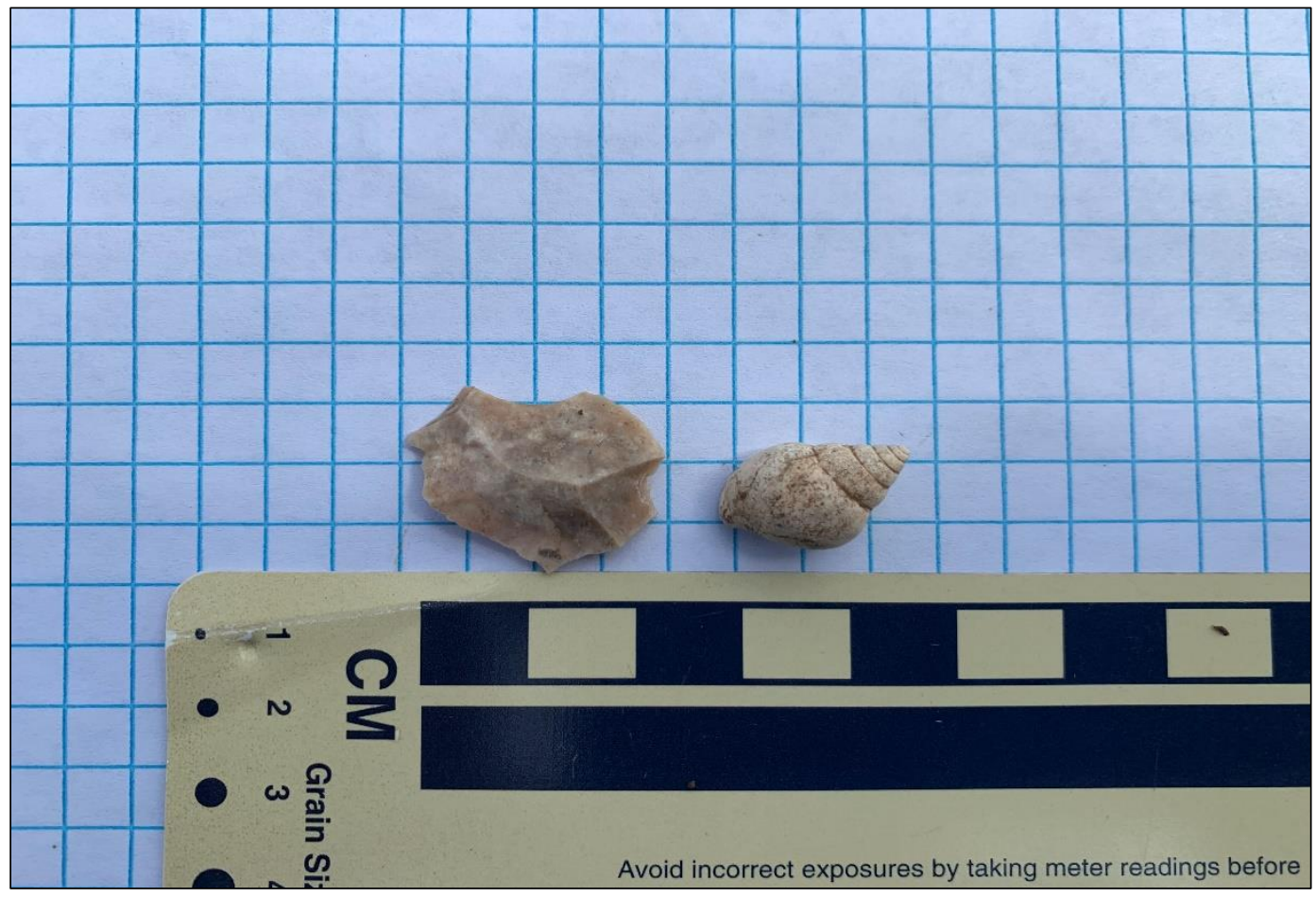

Figure 28. View of Chert Flake and Rabdotus Snail Shell 
around this initial discovery failed to produce any additional evidence of prehistoric cultural activity at this location, so the chert flake was recorded as an isolated artifact occurrence but was not documented as an archeological site. One Rabdotus snail shell was found in the same shovel test as the flake; however, given the overall dearth of cultural materials at this location, it is highly questionable that the presence of the snail shell is suggestive of cultural activity. No other cultural resources of prehistoric or historic age were recorded within the project area during the pedestrian survey, shovel testing, or backhoe trenching. 


\subsection{SUMMARY AND RECOMMENDATIONS}

\subsection{CONCEPTUAL FRAMEWORK}

The archeological investigations documented in this report were undertaken with three primary management goals in mind:

- Locate all historic and prehistoric archeological resources that occur within the designated survey area.

- Evaluate the significance of these resources regarding their potential for inclusion in the NRHP and for designation as SALs.

- Formulate recommendations for the treatment of these resources based on their NRHP and SAL evaluations.

At the survey level of investigation, the principal research objective is to inventory the cultural resources within the project area and to make preliminary determinations of whether or not the resources meet one or more of the pre-defined eligibility criteria set forth in the state and/or federal codes, as appropriate. Usually, management decisions regarding archeological properties are a function of the potential importance of the sites in addressing defined research needs, though historic-age sites may also be evaluated in terms of their association with important historic events and/or personages. Under the NHPA and the Antiquities Code of Texas, archeological resources are evaluated according to criteria established to determine the significance of archeological resources for inclusion in the NRHP and for designation as SALs, respectively.

Analyses of the limited data obtained at the survey level are rarely sufficient to contribute in a meaningful manner to defined research issues. The objective is rather to determine which archeological sites could be most profitably investigated further in pursuance of regional, methodological, or theoretical research questions. Therefore, adequate information on site function, context, and chronological placement from archeological and, if appropriate, historical perspectives is essential for archeological evaluations. Because research questions vary as a function of geography and temporal period, determination of the site context and chronological placement of cultural properties is a particularly important objective during the inventory process. 


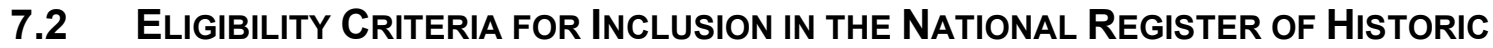 Places}

Determinations of eligibility for inclusion in the NRHP are based on the criteria presented in 36 CFR $\$ 60.4(a-d)$. The four criteria of eligibility are applied following the identification of relevant historical themes and related research questions:

The quality of significance in American history, architecture, archeology, and culture is present in districts, sites, buildings, structures, and objects that possess integrity of location, design, setting, materials, workmanship, feeling, and association, and:

a. [T]hat are associated with events that have made a significant contribution to the broad patterns of our history; or,

b. [T]hat are associated with the lives of persons significant in our past; or,

c. [T] hat embody the distinctive characteristics of a type, period, or method of construction, or that represent a significant and distinguishable entity whose components may lack individual distinction; or,

d. [T]hat have yielded, or may be likely to yield, information important in prehistory or history.

The first step in the evaluation process is to define the significance of the property by identifying the particular aspect of history or prehistory to be addressed and the reasons why information on that topic is important. The second step is to define the kinds of evidence or the data requirements that the property must exhibit to provide significant information. These data requirements in turn indicate the kind of integrity that the site must possess to be significant. This concept of integrity relates both to the contextual integrity of such entities as structures, districts, or archeological deposits and to the applicability of the potential database to pertinent research questions. Without such integrity, the significance of a resource is very limited.

For an archeological resource to be eligible for inclusion in the NRHP, it must meet legal standards of eligibility that are determined by three requirements: (1) properties must possess significance, (2) the significance must satisfy at least one of the four criteria for eligibility listed above, and (3) significance should be derived from an understanding of historic context. As discussed here, historic context refers to the organization of information concerning prehistory and history according to various periods of development in various times and at various places. Thus, the significance of a property can best be understood through knowledge of historic development and the relationship of the resource to other, similar properties within a particular period of development. Most prehistoric sites are usually only eligible for inclusion in the NRHP under Criterion $\mathrm{D}$, which considers their potential to contribute data important to an understanding of prehistory. All four criteria employed for determining NRHP eligibility potentially can be brought to bear for historic sites. 


\subsection{Eligibility CRITERIA for Listing as A StATE ANTIQUities LANDMARK}

The criteria for determining the eligibility of a prehistoric or historic cultural property for designation as an SAL are presented in Chapter 191, Subchapter D, Section 191.092 of the Antiquities Code of Texas, which states that SALs include:

Sites, objects, buildings, artifacts, implements, and locations of historical, archeological, scientific, or educational interest including those pertaining to prehistoric and historical American Indians or aboriginal campsites, dwellings, and habitation sites, their artifacts and implements of culture, as well as archeological sites of every character that are located in, on, or under the surface of any land belonging to the State of Texas or to any county, city, or political subdivision of the state are state antiquities landmarks and are eligible for designation.

For the purposes of assessing the eligibility of a historic property for designation as an SAL, a historic site, structure, or building has historical interest if the site, structure, or building:

1. [W]as the site of an event that has significance in the history of the United States or the State of Texas;

2. [W]as significantly associated with the life of a famous person;

3. [W]as significantly associated with an event that symbolizes an important principle or ideal;

4. [R]epresents a distinctive architectural type and has value as an example of a period, style, or construction technique; or,

5. [l]s important as part of the heritage of a religious organization, ethic group, or local society.

The Antiquities Code of Texas establishes the THC as the legal custodian of all cultural resources, historic and prehistoric, within the public domain of the State of Texas. Under Part II of Title 13 of the Texas Administrative Code (13 TAC 26), the THC may designate a historic building, structure, cultural landscape, or non-archeological site, object, or district as an SAL if it meets at least one of following criteria:

A. [T]he property is associated with events that have made a significant contribution to the broad patterns of our history, including importance to a particular cultural or ethnic group;

B. [T]he property is associated with the lives of persons significant in our past;

C. [T] he property embodies the distinctive characteristics of a type, period, or method of construction, represents the work of a master, possesses high artistic values, or represents a significant and distinguishable entity whose components may lack individual distinction;

D. [T]he property has yielded, or may be likely to yield, information important in Texas culture or history. 
Furthermore, the THC may designate an archeological site as an SAL if the site meets one or more of the following criteria:

1. [T] he site has the potential to contribute to a better understanding of the prehistory and/or history of Texas by the addition of new and important information;

2. [T]he site's archeological deposits and the artifacts within the site are preserved and intact, thereby supporting the research potential or preservation interests of the site;

3. [T] he site possesses unique or rare attributes concerning Texas prehistory and/or history;

4. [T]he study of the site offers the opportunity to test theories and methods of preservation, thereby contributing to new scientific knowledge; or,

5. [T]he high likelihood that vandalism and relic collecting has occurred or could occur, and official landmark designation is needed to ensure maximum legal protection, or alternatively further investigations are needed to mitigate the effects of vandalism and relic collecting when the site cannot be protected.

\subsection{SUMMARY OF INVENTORY RESULTS}

From October 1 to 3, on November 4, and on November 22, 2019, Horizon archeologists Jesse Dalton, McKinzie Froese, Amy Goldstein, Elizabeth Sefton, and Jared Wiersema conducted an intensive cultural resources survey of the project area, including pedestrian walkover with shovel testing and backhoe trenching. The survey was performed under the supervision of Jeffrey D. Owens, who served as Principal Investigator, under Texas Antiquities Permit No. 9114. The purpose of the survey was to locate any significant cultural resources that potentially would be impacted by the proposed undertaking. Horizon's archeologists traversed the project area on foot and thoroughly inspected the modern ground surface for aboriginal and historic-age cultural resources.

Overall, vegetation across the entire project area generally consisted of short- to mediumlength grasses interspersed with mature live oak and cedar trees, which afforded fair to good ground surface visibility (30 to 60\%). Within the riparian zone of Onion Creek, vegetation consisted of tall, dense grass and mature honey mesquite, cedar, live oak, and hackberry trees, which provided poor ground surface visibility $(<30 \%)$.

The West Interceptor segment runs along the gravelly terraces of Onion Creek. Topographically, this segment of the project area consists of steep limestone steps and rocky outcrops that give way to flat, open fields. The proposed interceptor crosses Onion Creek at three locations, and the lower stream terraces of the creek have extensive gravel bars and debris associated with high-energy flooding. Soil profiles typically consist of a shallow A horizon of hard, calcareous clay loam underlain by dense gravelly deposits; however, in the southeastern portion of the West Interceptor, deeper clayey loam alluvium underlain by limestone bedrock was encountered.

The Reclaimed Water Line segment traverses the west-facing hillslopes of upland ridges east of Onion Creek. Approximately the southeastern half of this segment of the project area 
Intensive Cultural Resources Survey of Proposed Dripping Springs

Wastewater System Improvements Project (EID 1), Dripping Springs, Hays County, Texas

would be constructed within the existing ROW of FM 12 west of the roadway, and construction, use, and ongoing maintenance of the roadway and associated facilities has resulted in extensive prior disturbances. Evidence of ground disturbance resulting from land clearing for housing developments and a transmission line were also noted within the northwestern portion of the proposed Reclaimed Water Line segment. The far northwestern end of the proposed Reclaimed Water Line segment skims the edge of the floodplain associated with a tributary of Onion Creek. Sediments on the terraces of this stream channel consist of calcareous loamy alluvial deposits, while soils across the upland portions of the segment consist of shallow deposits of gravelly clay and clay loam underlain by naturally degrading limestone bedrock.

The water reclamation facility expansion and effluent pond segment are located on the upper terraces northeast of Onion Creek. The water reclamation facility is an existing industrial facility surrounded by septic fields, and prior disturbances from construction, use, and ongoing maintenance of the facility are extensive. The proposed expansion area to the north of the existing facility is currently utilized as a septic field. Sediments within this segment of the project area consist of shallow, gravelly, calcareous loamy to clayey loam alluvium underlain by naturally degrading limestone bedrock.

In addition to a pedestrian walkover, the TSMASS require a minimum of 16 subsurface shovel tests per 1.6 kilometers (1.0 mile) for each 30.5-meter- (100.0-foot-) wide transect (or fraction thereof) for linear surveys unless field conditions warrant more shovel tests (e.g., in cultural high-probability areas) or fewer shovel tests (e.g., on steep slopes, in areas with excellent ground surface visibility). For block-area surveys, the TSMASS require two shovel tests per 0.4 hectare (1.0 acre) for project areas between 1.2 and 4.0 hectares (3.0 and 10.0 acres) in size. As such, a minimum of 37 shovel tests would be required within the West Interceptor segment, 13 shovel tests would be required within the Reclaimed Water Line segment, and 16 shovel tests would be required within the proposed water reclamation facility expansion and effluent pond area, for a total of 66 shovel tests for the project area as a whole. Horizon excavated a total of 106 shovel tests during the survey, including 82 shovel tests within the West Interceptor segment, 13 shovel tests within the Reclaimed Water Line segment, and 11 shovel tests within the facility expansion and effluent pond area. The shovel tests within the proposed facility expansion and effluent pond area were not all excavated directly within the final proposed construction footprint as the boundaries of this portion of the project area had not been firmly determined at the time of the survey, and no shovel tests were excavated within the existing water reclamation facility due to the extent of observable prior disturbances within this area. Overall, Horizon exceeded the minimum number of shovel tests required for the project area as a whole, and it is Horizon's opinion that shovel testing was capable of fully penetrating sediments with the potential to contain subsurface archeological deposits (with the exception noted below where backhoe trenches were excavated along a portion of the West Interceptor segment).

In addition to shovel testing, Horizon excavated four backhoe trenches within the southeastern portion of the proposed West Interceptor segment. The trenches were excavated at roughly 100.0-meter (328.0-foot) intervals along the proposed centerline to depths ranging from 105.0 to 350.0 centimeters (41.3 to 137.8 inches) below surface. Sediments observed within trench profiles typically consisted of moderately deep deposits of grayish-brown fine clay loam 
over yellowish-brown fine sandy loam. Dense deposits of river cobbles and/or naturally degrading limestone bedrock were observed at the base of three of the four trenches, and it is Horizon's opinion that backhoe trenching was capable of fully penetrating sediments with the potential to contain archeological deposits.

One chert flake was recorded in a shovel test (ST AG30) at a depth of 0.0 to 30.0 centimeters ( 0.0 to 11.8 inches) below surface at the far northwestern end of the West Interceptor project segment. Supplemental delineation shovel tests excavated around this initial discovery failed to produce any additional evidence of prehistoric cultural activity at this location, so the chert flake was recorded as an isolated artifact occurrence but was not documented as an archeological site. No other cultural resources of prehistoric or historic age were recorded within the project area during the pedestrian survey, shovel testing, or backhoe trenching.

\subsection{MANAgement ReCOMmendations}

Based on the results of the survey-level investigations documented in this report, no cultural resources would be affected by the proposed undertaking. In accordance with 36 CFR 800.4 , Horizon has made a reasonable and good-faith effort to identify historic properties within the project area. No cultural resources were identified within the project area that meet the criteria for designation as SALs according to 13 TAC 26 or for inclusion in the NRHP according to 36 CFR 60.4. Horizon recommends a finding of "no historic properties affected," and no further archeological work is recommended in connection with the proposed undertaking. However, human burials, both prehistoric and historic, are protected under the Texas Health and Safety Code. In the event that any human remains or burial objects are inadvertently discovered at any point during construction, use, or ongoing maintenance in the project area, even in previously surveyed areas, all work should cease immediately in the vicinity of the inadvertent discovery, and the THC should be notified immediately. Following completion of the project, all project records will be prepared for permanent curation at TARL. 


\subsection{REFERENCES CITED}

Adovasio, J.M., J. Donahue, and R. Stuckenrath

1990 The Meadowcroft Rockshelter Chronology 1975-1990. American Antiquity 55:348354.

Blair, W. F.

1950 The Biotic Provinces of Texas. Texas Journal of Science 2:93-117.

Bomar, G.W.

1983 Texas Weather. University of Texas Press, Austin.

Bryant, V. M., Jr., and R.G. Holloway

1985 A Late-Quaternary Paleoenvironmental Record of Texas: An Overview of the Pollen Evidence. In Pollen Records of Late-Quaternary North American Sediments, edited by V.M. Bryant, Jr., and R.G. Holloway, pp. 39-70. American Association of Stratigraphic Palynologists Foundation, Dallas, Texas.

Carlisle, J.D.

2010 Tonkawa Indians. The Handbook of Texas Online. <http://www.tshaonline.org/ handbook/online/articles/bmt68)]>. Uploaded June 15, 2010. Accessed August 20, 2019.

Carr, J.T.

1967 Climate and Physiography of Texas. Texas Water Development Board, Report No. 53, Austin.

Cecil, P.F., and D.P. Greene

2010 Hays County. The Handbook of Texas Online. <https://tshaonline.org/ handbook/online/articles/hch11>. Uploaded June 15, 2010. Accessed August 20, 2019.

Chipman, D.E.

1992 Spanish Texas: 1519-1821. University of Texas Press: Austin.

Collins, M.B.

1995 Forty Years of Archeology in Central Texas. Bulletin of the Texas Archeological Society 66:361-400. 
Dice, L.R.

1943 The Biotic Provinces of North America. University of Michigan Press, Ann Arbor.

Dillehay, T.D, C. Ramirez, M. Pino, M.B. Collins, J. Rossen, and J.D. Pino-Navarro

2008 Monte Verde: Seaweed, Food, Medicine, and the Peopling of South America. Science 320(5877):784-786.

Environmental Systems Research Institute (ESRI)

2018 Digital orthographic photography sourced by ESRI for ArcGIS Online. <arcgis.com>. Accessed November 18, 2018.

Folsom, B.

2010 San Marcos de Neve. The Handbook of Texas Online. <https://tshaonline.org/ handbook/online/articles/hvs21>. Uploaded June 15, 2010. Accessed August 20, 2019.

Foster, W.C.

2008 Historic Native Peoples of Texas. The University of Texas Press, Austin.

Jones, W.K.

1969 Notes on the History and Material Culture of the Tonkawa Indians. Smithsonian Contributions to Anthropology, Volume 2, Number 5. Smithsonian Press, Washington, D.C.

Jurney, D.H., F. Winchell, and R.W. Moir

1989 Cultural Resources Overview of the National Grasslands in North Texas: Studies in Predictive Archaeological Modeling for the Caddo and LBJ Grasslands. Archaeology Research Program, Institute for the Study of Earth and Man, Southern Methodist University, Dallas. Submitted to the US Forest Service, Lufkin, Texas.

Larkin, T.J., and G.W. Bomar

1983 Climatic Atlas of Texas. Publication LP-192. Texas Department of Water Resources, Austin.

Meltzer, D.J.

2009 First People in a New world: Colonizing Ice Age America. University of California Press, Berkeley.

Nance, J.M.

2010 Nance, Ezekiel Edward. The Handbook of Texas Online. <https://tshaonline.org/ handbook/online/articles/fna13>. Uploaded June 15, 2010. Accessed August 20, 2019.

Natural Resources Conservation Service (NRCS)

2019 Web Soil Survey. <http://websoilsurvey.nrcs.usda.gov/app/WebSoilSurvey.aspx>. Accessed December 14, 2019. 
Intensive Cultural Resources Survey of Proposed Dripping Springs

Wastewater System Improvements Project (EID 1), Dripping Springs, Hays County, Texas

National Environmental Title Research (NETR)

2019 Historic Aerials by NETR Online. <http://www.historicaerials.com>. Accessed September 5, 2019.

Newcomb, W.W., Jr.

1961 The Indians of Texas: From Prehistoric to Modern Times. The University of Texas Press, Austin.

Open Street Map (OSM)

2019 OpenStreetMap. < http://www.openstreetmap .org>. Available under the Open Database License: <www.opendatacommons.org/licenses/odbl>. Accessed December 13, 2019.

Owens, J.D.

2005 Cultural Resource Survey of the Dripping Springs Wastewater Treatment System, Dripping Springs, Hays County, Texas. HJN 050073. Horizon Environmental Services, Inc., Austin, Texas.

2007 Cultural Resources Survey of 2.4 Miles of Proposed Pipeline Reroutes Dripping Springs Wastewater Treatment System, Dripping Springs, Hays County, Texas. HJN 050073.002. Horizon Environmental Services, Inc., Austin, Texas

Patterson, L.W.

1980 The Owen Site, 41HR315: A Long Occupation Sequence in Harris County, Texas. Houston Archeological Society, Report No. 3.

1995 The Archeology of Southeast Texas. Bulletin of the Texas Archeological Society 66:239-264

Phillips Cemetery

2019 Phillips Cemetery-About US. <https://www.phillipscemetery.com/about>. Accessed October 23, 2019.

Prewitt, E.

1981 Cultural Chronology in Central Texas. In Bulletin of the Texas Archeological Society 52:65-90.

1985 From Circleville to Toyah: Comments on Central Texas Chronology. Bulletin of the Texas Archeological Society 53:201-238.

Ricklis, R.A.

1994 Toyah Components: Evidence for Occupation in the Project Area During the Latter Part of the Late Prehistoric Period. In Archaic and Late Prehistoric Human Ecology in the Middle Onion Creek Valley, Hays County, Texas, by R.A. Ricklis and M.B. Collins, pp. 207-316. Studies in Archeology, No. 19. Texas Archeological Research Laboratory, The University of Texas at Austin. 
Rodrigues, K., W.J. Rink, M.B. Collins, T.J. Williams, A. Keen-Zebert, and G.I. Lopez

2016 OSL Ages of the Clovis, Late Paleoindian, and Archaic components at Area 15 of the Gault Site, Central Texas, USA. Journal of Archaeological Science, Report No. 7, pp. 94-103.

Swanton, J.R.

1915 Linguistic Position of the Tribes of Southern Texas and Northeastern Mexico. American Anthropologist 17:17-40.

1940 Linguistic Material from the Tribes of Southern Texas and North-eastern Mexico. Bureau of American Ethnology, Bulletin No. 127. Washington, D.C.

Texas Historical Commission (THC)

2019 Texas Archeological Sites Atlas Restricted Database. <https://atlas.thc.state.tx.us/>. Accessed September 18, 2019.

Thornwaite, C.W.

1948 An Approach Toward a Rational Classification of Climate. Geographical Review 38:55-94.

Timmons, J.T.

1973 The Referendum in Texas on the Ordinance of Secession, February 23, 1861: The Vote. East Texas Historical Journal Vol. 11, No. 2.

US Geological Survey (USGS)

1986 7.5-minute series topographic maps, Dripping Springs, Texas, quadrangle.

2020 Texas Geology Web Map Viewer. <https://txpub.usgs.gov/txgeology/>. Accessed January 6, 2020.

Wade, M.F.

2003 The Native Americans of the Texas Edwards Plateau: 1582-1799. The University of Texas Press, Austin.

Wheat, J.B.

1953 The Addicks Dam Site. Bulletin 154:143-252. Bureau of American Ethnology, US Government Printing Office, Washington, D.C.

Williamson, R.L.

2010 Kerr, Alfred Benjamin Fontaine. The Handbook of Texas Online. <https://tshaonline.org/handbook/online/articles/fke32>. Uploaded June 15, 2010. Accessed August 20, 2019.

Williams, T.J., M.B. Collins, K. Rodrigues, W.J. Rink, N. Velchoff, A. Keen-Zebert, A. Gilmer, C.D. Frederick, S.J. Ayala, and E.R. Prewitt

2018 Evidence of an Early Projectile Point Technology in North America at the Gault Site, Texas, USA. Science Advances 4:7:eaar5954. 


\section{APPENDIX A:}

Shovel Test Data 

Intensive Cultural Resources Survey of Proposed Dripping Springs

Wastewater System Improvements Project (EID 1), Dripping Springs, Hays County, Texas

Table A-1. Shovel Test Summary Data

\begin{tabular}{|c|c|c|c|c|c|}
\hline \multirow{2}{*}{$\begin{array}{l}\text { ST } \\
\text { No. }\end{array}$} & \multicolumn{2}{|c|}{ UTM Coordinates ${ }^{1}$} & \multirow{2}{*}{$\begin{array}{l}\text { Depth } \\
\text { (cmbs) }\end{array}$} & \multirow[b]{2}{*}{ Soils } & \multirow[b]{2}{*}{ Artifacts } \\
\hline & Northing & Easting & & & \\
\hline \multirow[t]{3}{*}{ AG1 } & 587098 & 3338495 & $0-10$ & Dark brown silty clay loam & None \\
\hline & & & $10-50$ & Brown silty loam & None \\
\hline & & & $50+$ & Degrading limestone bedrock & None \\
\hline \multirow[t]{3}{*}{ AG2 } & 587088 & 3338595 & $0-15$ & Yellowish-brown sand & None \\
\hline & & & $15-55$ & Brown silty clay loam & None \\
\hline & & & $55+$ & Degrading limestone bedrock & None \\
\hline AG3 & 587039 & 3338679 & $0-85+$ & Brown silty clay loam & None \\
\hline \multirow[t]{3}{*}{ AG4 } & 586997 & 3338767 & $0-55$ & Very dark brown clay loam & None \\
\hline & & & $55-60$ & Dark brown sandy clay loam & None \\
\hline & & & $60+$ & Degrading limestone bedrock & None \\
\hline \multirow[t]{3}{*}{ AG5 } & 586972 & 3338869 & $0-35$ & Dark brown sandy clay & None \\
\hline & & & $35-40$ & Dark brown sandy clay loam & None \\
\hline & & & $40+$ & Gravel bar & None \\
\hline \multirow[t]{2}{*}{ AG6 } & 586950 & 3338964 & & $\begin{array}{l}\text { Brown sandy silty loam with limestone } \\
\text { gravels and cobbles }\end{array}$ & None \\
\hline & & & $15+$ & Degrading limestone bedrock & None \\
\hline AG7 & 586936 & 3339013 & $0-75+$ & Very compact brown sandy loam & None \\
\hline \multirow[t]{2}{*}{ AG8 } & 586915 & 3339107 & $0-25$ & Brown sand & None \\
\hline & & & $25-75+$ & Very compact brown fine sand & None \\
\hline \multirow[t]{2}{*}{ AG9 } & 586869 & 3339258 & $0-25$ & Brown loamy sand & None \\
\hline & & & $25+$ & Degrading limestone bedrock & None \\
\hline \multirow[t]{2}{*}{ AG10 } & 586838 & 3339295 & $0-15$ & Brown loamy sand & None \\
\hline & & & $15+$ & Degrading limestone bedrock & None \\
\hline \multirow[t]{2}{*}{ AG11 } & 586759 & 3339357 & $0-30$ & Brown loamy sand & None \\
\hline & & & $30+$ & Degrading limestone bedrock & None \\
\hline \multirow[t]{2}{*}{ AG12 } & 586661 & 3339386 & $0-45$ & Brown compact loamy sand & None \\
\hline & & & $45+$ & Degrading limestone bedrock & None \\
\hline AG13 & 586564 & 3339419 & $0-40+$ & Compact brown loamy sand & None \\
\hline \multirow[t]{2}{*}{ AG14 } & 585963 & 3339540 & $0-5$ & Brown loamy sand & None \\
\hline & & & $5+$ & Degrading limestone bedrock & None \\
\hline \multirow[t]{2}{*}{ AG15 } & 586021 & 3339523 & $0-5$ & Brown loamy sand & None \\
\hline & & & $5+$ & Degrading limestone bedrock & None \\
\hline AG16 & 586062 & 3339495 & $0-5+$ & Brown loamy sand & None \\
\hline
\end{tabular}


Table A-1. Shovel Test Summary Data (cont.)

\begin{tabular}{|c|c|c|c|c|c|}
\hline \multirow{2}{*}{$\begin{array}{l}\text { ST } \\
\text { No. }\end{array}$} & \multicolumn{2}{|c|}{ UTM Coordinates $^{1}$} & \multirow{2}{*}{$\begin{array}{l}\text { Depth } \\
\text { (cmbs) }\end{array}$} & \multirow[b]{2}{*}{ Soils } & \multirow[b]{2}{*}{ Artifacts } \\
\hline & Northing & Easting & & & \\
\hline & & & $5-10$ & Dark brown sandy clay loam & None \\
\hline & & & $10+$ & Degrading limestone bedrock & None \\
\hline \multirow[t]{2}{*}{ AG17 } & 586121 & 3339521 & $0-15$ & Black sandy clay loam & None \\
\hline & & & $15+$ & Degrading limestone bedrock & None \\
\hline \multirow[t]{2}{*}{ AG18 } & 586170 & 3339516 & $0-10$ & Very dark grayish-brown sandy loam & None \\
\hline & & & $10+$ & Degrading limestone bedrock & None \\
\hline \multirow[t]{2}{*}{ AG19 } & 586219 & 3339513 & $0-15$ & Very dark grayish-brown sandy loam & None \\
\hline & & & $15+$ & Degrading limestone bedrock & None \\
\hline \multirow[t]{2}{*}{ AG20 } & 586268 & 3339510 & $0-15$ & Very dark grayish-brown sandy loam & None \\
\hline & & & $15+$ & Degrading limestone bedrock & None \\
\hline \multirow[t]{3}{*}{ AG21 } & 586325 & 3339512 & $0-5$ & Very dark grayish-brown loamy sand & None \\
\hline & & & $5-20$ & Very dark grayish-brown loamy sand & None \\
\hline & & & $20+$ & Degrading limestone bedrock & None \\
\hline \multirow[t]{2}{*}{ AG22 } & 586376 & 3339507 & $0-10$ & Brown loamy sand & None \\
\hline & & & $10+$ & Degrading limestone bedrock & None \\
\hline \multirow[t]{3}{*}{ AG23 } & 586428 & 3339496 & $0-10$ & Brown loamy sand & None \\
\hline & & & $10-30$ & Brown loamy sand with limestone gravels & None \\
\hline & & & $30+$ & Degrading limestone bedrock & None \\
\hline \multirow[t]{3}{*}{ AG24 } & 586476 & 3339485 & $0-30$ & Brown loamy sand & None \\
\hline & & & $30-35$ & Brown loamy sand with limestone gravels & None \\
\hline & & & $35+$ & Degrading limestone bedrock & None \\
\hline \multirow[t]{2}{*}{ AG25 } & 586526 & 3339476 & $0-35$ & Brown sandy loam & None \\
\hline & & & $35+$ & Degrading limestone bedrock & None \\
\hline \multirow[t]{2}{*}{ AG26 } & 586570 & 3339455 & $0-15$ & Brown sandy loam & None \\
\hline & & & $15+$ & Degrading limestone bedrock & None \\
\hline \multirow[t]{2}{*}{ AG27 } & 585639 & 3339680 & $0-35$ & Brown sandy loam & None \\
\hline & & & $35+$ & Degrading limestone bedrock & None \\
\hline \multirow[t]{2}{*}{ AG28 } & 585600 & 3339712 & $0-25$ & Brown sandy clay loam with gravels & None \\
\hline & & & $25+$ & Degrading limestone bedrock & None \\
\hline \multirow[t]{3}{*}{ AG29 } & 585153 & 3340060 & $0-30$ & Black clay loam with limestone gravels & None \\
\hline & & & $30-35$ & Black clay loam with limestone gravels & None \\
\hline & & & $35+$ & Degrading limestone bedrock & None \\
\hline
\end{tabular}


Table A-1. Shovel Test Summary Data (cont.)

\begin{tabular}{|c|c|c|c|c|c|}
\hline \multirow{2}{*}{$\begin{array}{l}\text { ST } \\
\text { No. }\end{array}$} & \multicolumn{2}{|c|}{ UTM Coordinates $^{1}$} & \multirow{2}{*}{$\begin{array}{l}\text { Depth } \\
\text { (cmbs) }\end{array}$} & \multirow[b]{2}{*}{ Soils } & \multirow[b]{2}{*}{ Artifacts } \\
\hline & Northing & Easting & & & \\
\hline AG30 & 585189 & 3340027 & $\begin{array}{c}0-30 \\
30-35 \\
35+\end{array}$ & $\begin{array}{l}\text { Black clay loam with limestone gravels } \\
\text { Black clay loam with limestone gravels } \\
\text { Degrading limestone bedrock }\end{array}$ & $\begin{array}{l}1 \text { flake } \\
\text { None } \\
\text { None }\end{array}$ \\
\hline AG31 & 585229 & 3340004 & $\begin{array}{c}0-45 \\
45-60 \\
60+\end{array}$ & $\begin{array}{l}\text { Black clay loam } \\
\text { Very dark gray clay loam } \\
\text { Limestone gravels }\end{array}$ & $\begin{array}{l}\text { None } \\
\text { None } \\
\text { None }\end{array}$ \\
\hline AG32 & 585200 & 3340024 & $\begin{array}{l}0-40 \\
40+\end{array}$ & $\begin{array}{l}\text { Dark brown clay loam } \\
\text { Limestone gravels }\end{array}$ & $\begin{array}{l}\text { None } \\
\text { None }\end{array}$ \\
\hline AG33 & 585203 & 3340019 & $\begin{array}{l}0-40 \\
40-50 \\
50+\end{array}$ & $\begin{array}{l}\text { Very dark grayish-brown clay loam with } \\
\text { limestone gravels } \\
\text { Dark brown clay loam with limestone } \\
\text { gravels } \\
\text { Limestone gravel }\end{array}$ & $\begin{array}{l}\text { None } \\
\text { None } \\
\text { None }\end{array}$ \\
\hline AG34 & 585180 & 3340033 & $\begin{array}{l}0-30 \\
30-35 \\
35+\end{array}$ & $\begin{array}{l}\text { Very dark gray clay loam with limestone } \\
\text { gravels } \\
\text { Dark brown clay loam with limestone } \\
\text { gravels } \\
\text { Limestone gravel }\end{array}$ & $\begin{array}{l}\text { None } \\
\text { None } \\
\text { None }\end{array}$ \\
\hline AG35 & 585171 & 3340038 & $\begin{array}{l}0-25 \\
25-30 \\
30+\end{array}$ & $\begin{array}{l}\text { Very dark gray clay loam with limestone } \\
\text { gravels } \\
\text { Dark brown clay loam with limestone } \\
\text { gravels } \\
\text { Limestone gravels }\end{array}$ & $\begin{array}{l}\text { None } \\
\text { None } \\
\text { None }\end{array}$ \\
\hline AG36 & 585186 & 3340018 & $\begin{array}{l}0-35 \\
35-45 \\
45+\end{array}$ & $\begin{array}{l}\text { Very dark gray clay loam with limestone } \\
\text { gravels } \\
\text { Dark brown clay loam with limestone } \\
\text { gravels } \\
\text { Limestone gravels }\end{array}$ & $\begin{array}{l}\text { None } \\
\text { None } \\
\text { None }\end{array}$ \\
\hline AG37 & 587098 & 3338495 & $\begin{array}{l}0-25 \\
25+\end{array}$ & $\begin{array}{l}\text { Very dark gray clay loam with limestone } \\
\text { gravels } \\
\text { Limestone gravels }\end{array}$ & $\begin{array}{l}\text { None } \\
\text { None }\end{array}$ \\
\hline AG38 & 587088 & 3338595 & $\begin{array}{l}0-35 \\
35-45+\end{array}$ & $\begin{array}{l}\text { Very dark gray clay loam with calcium } \\
\text { carbonate inclusions } \\
\text { Dark brown clay loam with dense limestone } \\
\text { gravels }\end{array}$ & $\begin{array}{l}\text { None } \\
\text { None }\end{array}$ \\
\hline
\end{tabular}


Table A-1. Shovel Test Summary Data (cont.)

\begin{tabular}{|c|c|c|c|c|c|}
\hline \multirow{2}{*}{$\begin{array}{l}\text { ST } \\
\text { No. }\end{array}$} & \multicolumn{2}{|c|}{ UTM Coordinates ${ }^{1}$} & \multirow{2}{*}{$\begin{array}{c}\text { Depth } \\
\text { (cmbs) } \\
\end{array}$} & \multirow[b]{2}{*}{ Soils } & \multirow[b]{2}{*}{ Artifacts } \\
\hline & Northing & Easting & & & \\
\hline AG39 & 587039 & 3338679 & $\begin{array}{l}0-30 \\
30+\end{array}$ & $\begin{array}{l}\text { Mottled dark brown and brown clay loam } \\
\text { with calcium carbonate inclusions and } \\
\text { limestone gravels } \\
\text { Limestone gravels }\end{array}$ & $\begin{array}{l}\text { None } \\
\text { None }\end{array}$ \\
\hline AG40 & 586997 & 3338767 & $0-30+$ & Dense, gravelly dark brown clay & None \\
\hline AG41 & 586972 & 3338869 & $\begin{array}{l}0-30 \\
30+\end{array}$ & $\begin{array}{l}\text { Dense, gravelly dark brown clay } \\
\text { Limestone gravels }\end{array}$ & $\begin{array}{l}\text { None } \\
\text { None }\end{array}$ \\
\hline AG42 & 586950 & 3338964 & $\begin{array}{l}0-30 \\
30+\end{array}$ & $\begin{array}{l}\text { Very dark brown clay loam } \\
\text { Limestone gravels }\end{array}$ & $\begin{array}{l}\text { None } \\
\text { None }\end{array}$ \\
\hline AG43 & 586936 & 3339013 & $\begin{array}{l}0-30 \\
30+\end{array}$ & $\begin{array}{l}\text { Very dark brown clay loam } \\
\text { Limestone gravels }\end{array}$ & $\begin{array}{l}\text { None } \\
\text { None }\end{array}$ \\
\hline AG44 & 586915 & 3339107 & $\begin{array}{l}0-15 \\
15+\end{array}$ & $\begin{array}{l}\text { Dark brown sandy clay loam } \\
\text { Limestone gravels }\end{array}$ & $\begin{array}{l}\text { None } \\
\text { None }\end{array}$ \\
\hline AG45 & 586869 & 3339258 & $\begin{array}{l}0-15 \\
15+ \\
\end{array}$ & $\begin{array}{l}\text { Dark brown sandy clay loam } \\
\text { Limestone gravels }\end{array}$ & $\begin{array}{l}\text { None } \\
\text { None }\end{array}$ \\
\hline AG46 & 588032 & 3338307 & $\begin{array}{l}0-15 \\
15+\end{array}$ & $\begin{array}{l}\text { Dark brown sandy clay loam } \\
\text { Limestone gravels }\end{array}$ & $\begin{array}{l}\text { None } \\
\text { None }\end{array}$ \\
\hline AG47 & 587732 & 3338503 & $0-5$ & Limestone gravels & None \\
\hline AG48 & 587656 & 3338543 & $\begin{array}{l}0-25 \\
25+\end{array}$ & $\begin{array}{l}\text { Grayish-brown sandy clay loam with } \\
\text { calcium carbonate inclusions } \\
\text { Degrading limestone bedrock }\end{array}$ & $\begin{array}{l}\text { None } \\
\text { None }\end{array}$ \\
\hline AG56 & 586268 & 3339510 & $\begin{array}{l}0-20 \\
20+\end{array}$ & $\begin{array}{l}\text { Dark brown loam with some limestone } \\
\text { gravels } \\
\text { Degrading limestone bedrock }\end{array}$ & $\begin{array}{l}\text { None } \\
\text { None }\end{array}$ \\
\hline AG59 & 586428 & 3339496 & $\begin{array}{l}0-20 \\
20-25+\end{array}$ & $\begin{array}{l}\text { Dark brown loam with few limestone } \\
\text { gravels } \\
\text { Dark brown loam with common limestone } \\
\text { gravels }\end{array}$ & $\begin{array}{l}\text { None } \\
\text { None }\end{array}$ \\
\hline ES01 & 587109 & 3338445 & $\begin{array}{l}0-20 \\
20-40+\end{array}$ & $\begin{array}{l}\text { Brown clay loam with dense limestone } \\
\text { gravels } \\
\text { Dense grayish-brown clay with dense } \\
\text { limestone gravels }\end{array}$ & $\begin{array}{l}\text { None } \\
\text { None }\end{array}$ \\
\hline ES02 & 587095 & 3338543 & $\begin{array}{l}0-30 \\
30-40+\end{array}$ & $\begin{array}{l}\text { Dense grayish-brown clay loam with } \\
\text { abundant calcium carbonate inclusions } \\
\text { Dense brown clay loam }\end{array}$ & $\begin{array}{l}\text { None } \\
\text { None }\end{array}$ \\
\hline
\end{tabular}


Intensive Cultural Resources Survey of Proposed Dripping Springs

Wastewater System Improvements Project (EID 1), Dripping Springs, Hays County, Texas

Table A-1. Shovel Test Summary Data (cont.)

\begin{tabular}{|c|c|c|c|c|c|}
\hline \multirow{2}{*}{$\begin{array}{l}\text { ST } \\
\text { No. }\end{array}$} & \multicolumn{2}{|c|}{ UTM Coordinates $^{1}$} & \multirow{2}{*}{$\begin{array}{l}\text { Depth } \\
\text { (cmbs) }\end{array}$} & \multirow[b]{2}{*}{ Soils } & \multirow[b]{2}{*}{ Artifacts } \\
\hline & Northing & Easting & & & \\
\hline ES03 & 587062 & 3338639 & $0-40+$ & $\begin{array}{l}\text { Gray clay loam with calcium carbonate } \\
\text { inclusions }\end{array}$ & None \\
\hline ES04 & 587019 & 3338723 & $\begin{array}{l}0-30 \\
30-40+\end{array}$ & $\begin{array}{l}\text { Dark brown clay loam with calcium } \\
\text { carbonate inclusions } \\
\text { Very dark brown clay with abundant } \\
\text { calcium carbonate inclusions and dense } \\
\text { limestone gravels }\end{array}$ & $\begin{array}{l}\text { None } \\
\text { None }\end{array}$ \\
\hline ES05 & 586981 & 3338820 & $0-30+$ & $\begin{array}{l}\text { Brown clay loam with calcium carbonate } \\
\text { inclusions and dense limestone gravels }\end{array}$ & None \\
\hline ES06 & 586960 & 3338916 & $0-30+$ & $\begin{array}{l}\text { Dense brown clay with calcium carbonate } \\
\text { inclusions and dense limestone gravels }\end{array}$ & None \\
\hline ES07 & 586928 & 3339062 & $0-40+$ & $\begin{array}{l}\text { Dense brown clay with calcium carbonate } \\
\text { inclusions and dense limestone gravels }\end{array}$ & None \\
\hline ES08 & 586910 & 3339155 & $\begin{array}{c}0-45 \\
45-50+\end{array}$ & $\begin{array}{l}\text { Grayish-brown sandy loam with gravels } \\
\text { Dense gravels }\end{array}$ & $\begin{array}{l}\text { None } \\
\text { None }\end{array}$ \\
\hline ES09 & 586906 & 3339205 & $\begin{array}{c}0-40 \\
40-45+\end{array}$ & $\begin{array}{l}\text { Gravelly brown sand } \\
\text { Dense gravels }\end{array}$ & $\begin{array}{l}\text { None } \\
\text { None }\end{array}$ \\
\hline ES10 & 586799 & 3339326 & $\begin{array}{l}0-30 \\
30-35+\end{array}$ & $\begin{array}{l}\text { Dense grayish-brown clay loam with dense } \\
\text { calcium carbonate } \\
\text { Dense gravels }\end{array}$ & $\begin{array}{l}\text { None } \\
\text { None }\end{array}$ \\
\hline ES11 & 586712 & 3339375 & $\begin{array}{l}0-35 \\
35-40+\end{array}$ & $\begin{array}{l}\text { Dense grayish-brown sandy clay loam with } \\
\text { calcium carbonate inclusions } \\
\text { Grayish-brown sandy loam with dense } \\
\text { gravels }\end{array}$ & $\begin{array}{l}\text { None } \\
\text { None }\end{array}$ \\
\hline ES12 & 586615 & 3339403 & $0-30+$ & Very dense grayish-brown clay loam & None \\
\hline ES13 & 586513 & 3339423 & $0-35+$ & Very dense grayish-brown clay loam & None \\
\hline ES14 & 586465 & 3339425 & $0-30+$ & Very dense grayish-brown clay loam & None \\
\hline ES15 & 586414 & 3339427 & $\begin{array}{c}0-20 \\
20-25+\end{array}$ & $\begin{array}{l}\text { Brown sandy loam } \\
\text { Yellowish-brown sandy loam with dense } \\
\text { gravels }\end{array}$ & $\begin{array}{l}\text { None } \\
\text { None }\end{array}$ \\
\hline ES17 & 586313 & 3339430 & $0-10+$ & Dense gravels & None \\
\hline ES18 & 586267 & 3339425 & 0 & Limestone bedrock & None \\
\hline ES19 & 586217 & 3339420 & 0 & Limestone bedrock & None \\
\hline ES20 & 586166 & 3339416 & 0 & Limestone bedrock & None \\
\hline ES21 & 586111 & 3339422 & $\begin{array}{c}0-5 \\
5-10+\end{array}$ & $\begin{array}{l}\text { Grayish-brown sandy loam } \\
\text { Dense gravels }\end{array}$ & $\begin{array}{l}\text { None } \\
\text { None }\end{array}$ \\
\hline ES22 & 586061 & 3339429 & $0-5$ & Grayish brown sandy loam & None \\
\hline
\end{tabular}


Table A-1. Shovel Test Summary Data (cont.)

\begin{tabular}{|c|c|c|c|c|c|}
\hline \multirow{2}{*}{$\begin{array}{l}\text { ST } \\
\text { No. }\end{array}$} & \multicolumn{2}{|c|}{ UTM Coordinates ${ }^{1}$} & \multirow{2}{*}{$\begin{array}{l}\text { Depth } \\
\text { (cmbs) }\end{array}$} & \multirow[b]{2}{*}{ Soils } & \multirow[b]{2}{*}{ Artifacts } \\
\hline & Northing & Easting & & & \\
\hline & & & $5-10+$ & Dense gravels & None \\
\hline ES23 & 586011 & 3339436 & $\begin{array}{c}0-40 \\
40-45+\end{array}$ & $\begin{array}{l}\text { Yellowish-brown sandy loam with dense } \\
\text { gravels } \\
\text { Dense gravels }\end{array}$ & $\begin{array}{l}\text { None } \\
\text { None }\end{array}$ \\
\hline ES24 & 585964 & 3339455 & $\begin{array}{r}0-30 \\
30-35+\end{array}$ & $\begin{array}{l}\text { Yellowish-brown sandy loam with dense } \\
\text { gravels } \\
\text { Dense gravels }\end{array}$ & $\begin{array}{l}\text { None } \\
\text { None }\end{array}$ \\
\hline ES25 & 585920 & 3339474 & $\begin{array}{l}0-30 \\
30-35+\end{array}$ & $\begin{array}{l}\text { Yellowish-brown sandy loam with dense } \\
\text { gravels } \\
\text { Dense gravels }\end{array}$ & $\begin{array}{l}\text { None } \\
\text { None }\end{array}$ \\
\hline ES26 & 585874 & 3339497 & $\begin{array}{r}0-30 \\
30-35+\end{array}$ & $\begin{array}{l}\text { Dense brown clay loam with dense calcium } \\
\text { carbonate inclusions } \\
\text { Dense gravels }\end{array}$ & $\begin{array}{l}\text { None } \\
\text { None }\end{array}$ \\
\hline ES27 & 585834 & 3339528 & $\begin{array}{l}0-20 \\
20-25+\end{array}$ & $\begin{array}{l}\text { Dense brown clay loam with dense calcium } \\
\text { carbonate inclusions } \\
\text { Dense gravels }\end{array}$ & $\begin{array}{l}\text { None } \\
\text { None }\end{array}$ \\
\hline ES28 & 585793 & 3339555 & $\begin{array}{c}0-10 \\
10-15+\end{array}$ & $\begin{array}{l}\text { Brown sandy loam } \\
\text { Dense gravels }\end{array}$ & $\begin{array}{l}\text { None } \\
\text { None }\end{array}$ \\
\hline ES29 & 585758 & 3339588 & $\begin{array}{c}0-30 \\
30-35+\end{array}$ & $\begin{array}{l}\text { Brown sandy loam } \\
\text { Dense gravels }\end{array}$ & $\begin{array}{l}\text { None } \\
\text { None }\end{array}$ \\
\hline ES30 & 585715 & 3339615 & $0-5+$ & Brown sandy loam & None \\
\hline ES31 & 585682 & 3339654 & $0-30+$ & $\begin{array}{l}\text { Very dense dark brown clay loam with } \\
\text { calcium carbonate inclusions }\end{array}$ & None \\
\hline ES32 & 585566 & 3339831 & $\begin{array}{r}0-30 \\
30-35+\end{array}$ & $\begin{array}{l}\text { Very dark brown clay loam with calcium } \\
\text { carbonate inclusions } \\
\text { Reddish-brown clay loam with dense } \\
\text { limestone gravels and caliche }\end{array}$ & $\begin{array}{l}\text { None } \\
\text { None }\end{array}$ \\
\hline ES33 & 585521 & 3339852 & $\begin{array}{c}0-40 \\
40-45+\end{array}$ & $\begin{array}{l}\text { Very dark brown clay loam with calcium } \\
\text { carbonate } \\
\text { Reddish-brown clay loam with dense } \\
\text { limestone gravels and caliche }\end{array}$ & $\begin{array}{l}\text { None } \\
\text { None }\end{array}$ \\
\hline ES34 & 585478 & 3339870 & $\begin{array}{l}0-30 \\
30-40+\end{array}$ & $\begin{array}{l}\text { Very dark brown clay loam with calcium } \\
\text { carbonate } \\
\text { Reddish-brown clay loam with dense } \\
\text { limestone gravels and caliche }\end{array}$ & $\begin{array}{l}\text { None } \\
\text { None }\end{array}$ \\
\hline ES35 & 585496 & 3339897 & $0-30+$ & $\begin{array}{l}\text { Very dark brown clay with light calcium } \\
\text { carbonate inclusions }\end{array}$ & None \\
\hline ES36 & 585429 & 3339892 & $0-40$ & Very dark brown clay & None \\
\hline
\end{tabular}


Table A-1. Shovel Test Summary Data (cont.)

\begin{tabular}{|c|c|c|c|c|c|}
\hline \multirow{2}{*}{$\begin{array}{l}\text { ST } \\
\text { No. }\end{array}$} & \multicolumn{2}{|c|}{ UTM Coordinates $^{1}$} & \multirow{2}{*}{$\begin{array}{l}\text { Depth } \\
\text { (cmbs) }\end{array}$} & \multirow[b]{2}{*}{ Soils } & \multirow[b]{2}{*}{ Artifacts } \\
\hline & Northing & Easting & & & \\
\hline & & & $40-45+$ & $\begin{array}{l}\text { Reddish brown clay loam with dense } \\
\text { gravels and calcium carbonate inclusions }\end{array}$ & None \\
\hline \multirow[t]{2}{*}{ ES37 } & 585381 & 3339902 & $0-30$ & Very dark brown clay & None \\
\hline & & & $30-35+$ & $\begin{array}{l}\text { Reddish-brown clay loam with dense } \\
\text { gravels and calcium carbonate inclusions }\end{array}$ & None \\
\hline \multirow[t]{2}{*}{ ES38 } & 585328 & 3339917 & $0-10$ & $\begin{array}{l}\text { Very dark brown clay with calcium } \\
\text { carbonate inclusions }\end{array}$ & None \\
\hline & & & $10-50+$ & $\begin{array}{l}\text { Brown clay loam with limestone cobbles } \\
\text { and dense calcium carbonate inclusions }\end{array}$ & None \\
\hline \multirow[t]{2}{*}{ ES39 } & 585282 & 3339937 & $0-40$ & $\begin{array}{l}\text { Very dark brown clay with calcium } \\
\text { carbonate inclusions }\end{array}$ & None \\
\hline & & & $40-50+$ & $\begin{array}{l}\text { Brown clay loam with limestone cobbles } \\
\text { and dense calcium carbonate inclusions }\end{array}$ & None \\
\hline \multirow[t]{3}{*}{ ES40 } & 585244 & 3339963 & $0-10$ & Brown clay loam with gravels & None \\
\hline & & & $10-50$ & $\begin{array}{l}\text { Brown clay with gravels and calcium } \\
\text { carbonate inclusions }\end{array}$ & None \\
\hline & & & $50-55+$ & Brown clay with dense gravels & None \\
\hline \multirow[t]{2}{*}{ ES41 } & 585192 & 3340037 & & $\begin{array}{l}\text { Brown clay loam with calcium carbonate } \\
\text { inclusions }\end{array}$ & \\
\hline & & & $35-40+$ & Dense gravels & None \\
\hline \multirow[t]{2}{*}{ ES118 } & 587921 & 3337937 & & $\begin{array}{l}\text { Disturbed brown clay with limestone } \\
\text { gravels }\end{array}$ & \\
\hline & & & $25-30+$ & Reddish-yellow clay with limestone cobbles & None \\
\hline \multirow[t]{3}{*}{ ES119 } & 588000 & 3338116 & $0-5$ & Brown loam & None \\
\hline & & & $5-20$ & Dark brown clay & None \\
\hline & & & $20+$ & Degrading limestone bedrock & None \\
\hline \multirow[t]{2}{*}{ ES120 } & 588046 & 3338408 & & $\begin{array}{l}\text { Reddish-brown silty clay with limestone } \\
\text { gravels }\end{array}$ & \\
\hline & & & $5+$ & Degrading limestone bedrock & None \\
\hline \multirow[t]{2}{*}{ ES121 } & 587934 & 3338500 & $0-35$ & Brown silty loam & None \\
\hline & & & $35+$ & Limestone bedrock & None \\
\hline \multirow[t]{2}{*}{ ES122 } & 587546 & 3338720 & $0-50$ & Grayish-brown silty loam & None \\
\hline & & & $50-55+$ & $\begin{array}{l}\text { Gray clay with dense calcium carbonate } \\
\text { inclusions }\end{array}$ & None \\
\hline MF03 & 588544 & 3336311 & $0-30+$ & $\begin{array}{l}\text { Mottled dark brown and brown clay with } \\
\text { calcium carbonate inclusions and limestone } \\
\text { gravels }\end{array}$ & None \\
\hline MF04 & 588657 & 3336228 & $0-25+$ & Dense dark brown gravelly clay & None \\
\hline
\end{tabular}


Table A-1. Shovel Test Summary Data (cont.)

\begin{tabular}{|c|c|c|c|c|c|}
\hline \multirow{2}{*}{$\begin{array}{l}\text { ST } \\
\text { No. }\end{array}$} & \multicolumn{2}{|c|}{ UTM Coordinates ${ }^{1}$} & \multirow{2}{*}{$\begin{array}{l}\text { Depth } \\
\text { (cmbs) }\end{array}$} & \multirow[b]{2}{*}{ Soils } & \multirow[b]{2}{*}{ Artifacts } \\
\hline & Northing & Easting & & & \\
\hline \multirow[t]{2}{*}{ MF05 } & \multirow[t]{2}{*}{588657} & \multirow[t]{2}{*}{3336121} & $0-30$ & $\begin{array}{l}\text { Sticky dark brown clay loam with limestone } \\
\text { gravels }\end{array}$ & None \\
\hline & & & $30+$ & Limestone bedrock & None \\
\hline MF06 & 588658 & 3336024 & $0-10+$ & Very dark brown clay loam & None \\
\hline \multirow[t]{2}{*}{ MF07 } & \multirow[t]{2}{*}{588581} & \multirow[t]{2}{*}{3336089} & $0-15$ & Dark grayish-brown clay loam & None \\
\hline & & & $15-35+$ & Very dense dark reddish-brown clay loam & None \\
\hline \multirow[t]{3}{*}{ MF08 } & \multirow[t]{3}{*}{588709} & \multirow[t]{3}{*}{3336284} & $0-15$ & Mottled dark brown and brown clay loam & None \\
\hline & & & $15-35$ & $\begin{array}{l}\text { Dark reddish-brown clay loam and dense } \\
\text { limestone gravels }\end{array}$ & None \\
\hline & & & $35+$ & Limestone bedrock & None \\
\hline MF13 & 587956 & 3338028 & $0-20+$ & $\begin{array}{l}\text { Dark grayish-brown clay loam with dense } \\
\text { limestone gravels }\end{array}$ & None \\
\hline MF14 & 588016 & 3338212 & $0-20+$ & $\begin{array}{l}\text { Dark grayish-brown clay loam with dense } \\
\text { limestone and chert gravels }\end{array}$ & None \\
\hline MF15 & 588036 & 3338496 & $0-15+$ & $\begin{array}{l}\text { Disturbed, mixed brown, gray, and pale } \\
\text { yellow sandy clay loam with dense gravels }\end{array}$ & None \\
\hline \multirow[t]{2}{*}{ MF16 } & \multirow[t]{2}{*}{587840} & \multirow[t]{2}{*}{3338500} & $0-5$ & Reddish-brown clay loam & None \\
\hline & & & $5+$ & Limestone bedrock & None \\
\hline \multirow[t]{2}{*}{ MF17 } & \multirow[t]{2}{*}{587601} & \multirow[t]{2}{*}{3338633} & & $\begin{array}{l}\text { Dark grayish-brown clay loam with dense } \\
\text { limestone gravels }\end{array}$ & None \\
\hline & & & $35-50+$ & $\begin{array}{l}\text { Brown clay loam with dense limestone } \\
\text { gravels }\end{array}$ & None \\
\hline
\end{tabular}

1 All UTM coordinates are located in Zone 14 and utilize the North American Datum of 1983 (NAD 83).

$\mathrm{cmbs}=$ Centimeters below surface

ST $=$ Shovel test

UTM = Universal Transverse Mercator 


\section{APPENDIX B:}

Backhoe Trench Data 

Table B-1. Backhoe Trench 1 (BHT-1)

Trench No.:

UTM Coordinates ${ }^{1}$ : Comment:

\section{BHT-1}

$0586965 \mathrm{E}, 3338895 \mathrm{~N}$

BHT-1 was oriented north to south and measured 5.5 meters (18.0 feet) in length. It was excavated on a terrace in the southeastern portion of the West Interceptor segment of the project area just west of and parallel to Onion Creek to examine potential alluvial soils adjacent to the creek.

\begin{tabular}{|c|c|c|c|}
\hline Zone & $\begin{array}{c}\text { Depth } \\
\text { (cmbs) }\end{array}$ & Description & Cultural Materials \\
\hline 1 & $0-24$ & $\begin{array}{l}\text { Dark grayish-brown fine clay loam; friable, somewhat plastic, } \\
\text { somewhat sticky consistency; granular subangular structure; } \\
\text { fine-medium size; weak-moderate grade; rootlets }(20 \%) ; \\
\text { gradual lower boundary }\end{array}$ & None \\
\hline 2 & $24-58$ & $\begin{array}{l}\text { Medium grayish-brown fine clay loam; friable, somewhat } \\
\text { plastic, somewhat sticky consistency; granular subangular } \\
\text { structure; fine-medium size; weak-moderate grade; gradual } \\
\text { lower boundary }\end{array}$ & None \\
\hline 3 & $58-105$ & $\begin{array}{l}\text { Light brown fine clay loam with } \mathrm{CaCO}_{3} \text { inclusions; friable, } \\
\text { somewhat plastic, somewhat sticky consistency; granular } \\
\text { subangular structure; medium size; weak-moderate grade; } \\
\text { abrupt lower boundary }\end{array}$ & None \\
\hline 4 & $105+$ & Limestone bedrock & None \\
\hline
\end{tabular}

$\mathrm{CaCO}_{3}=$ Calcium carbonate

cmbs $=$ centimeters below surface 


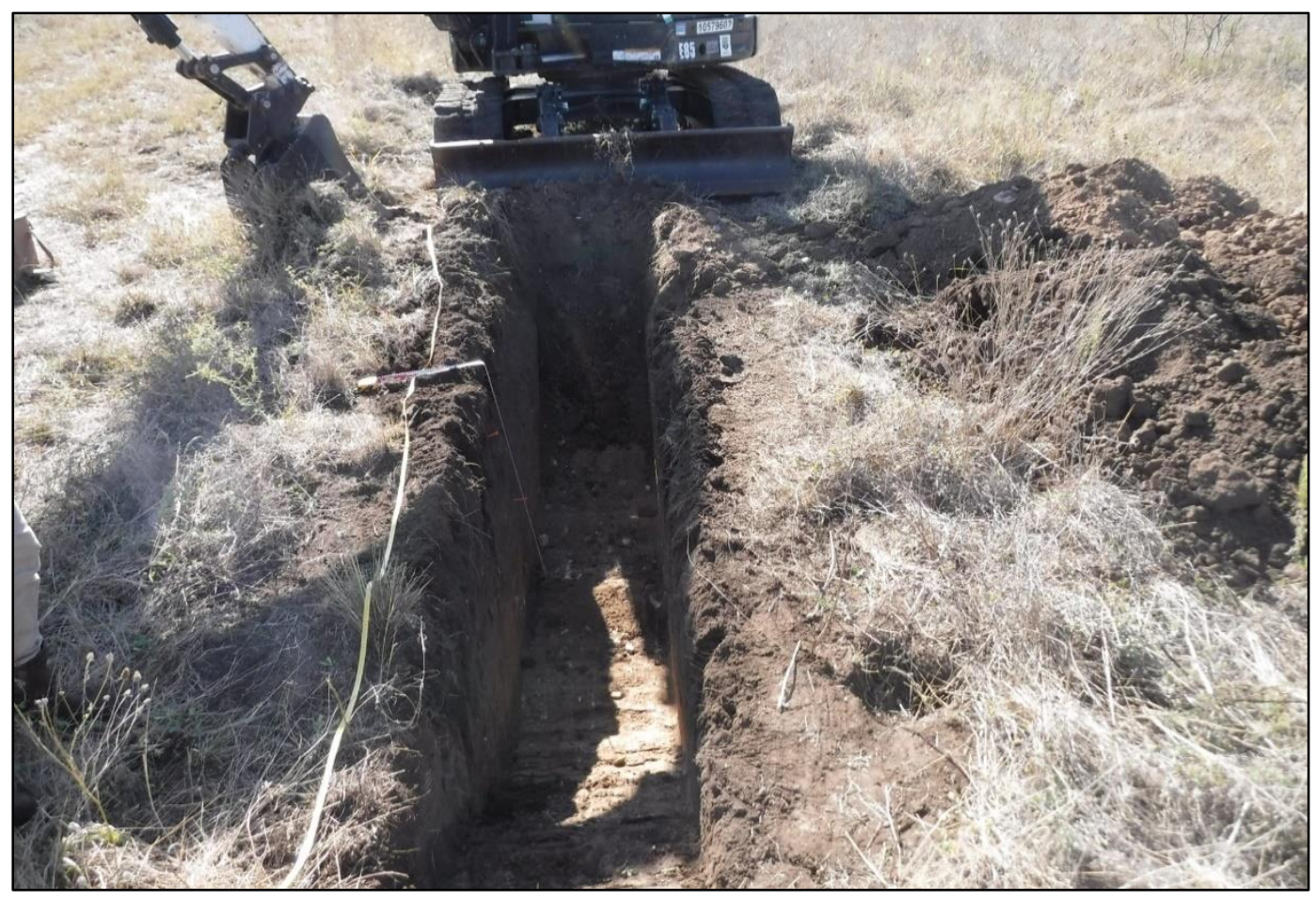

Figure B-1. Overview of BHT-1 (Facing South)

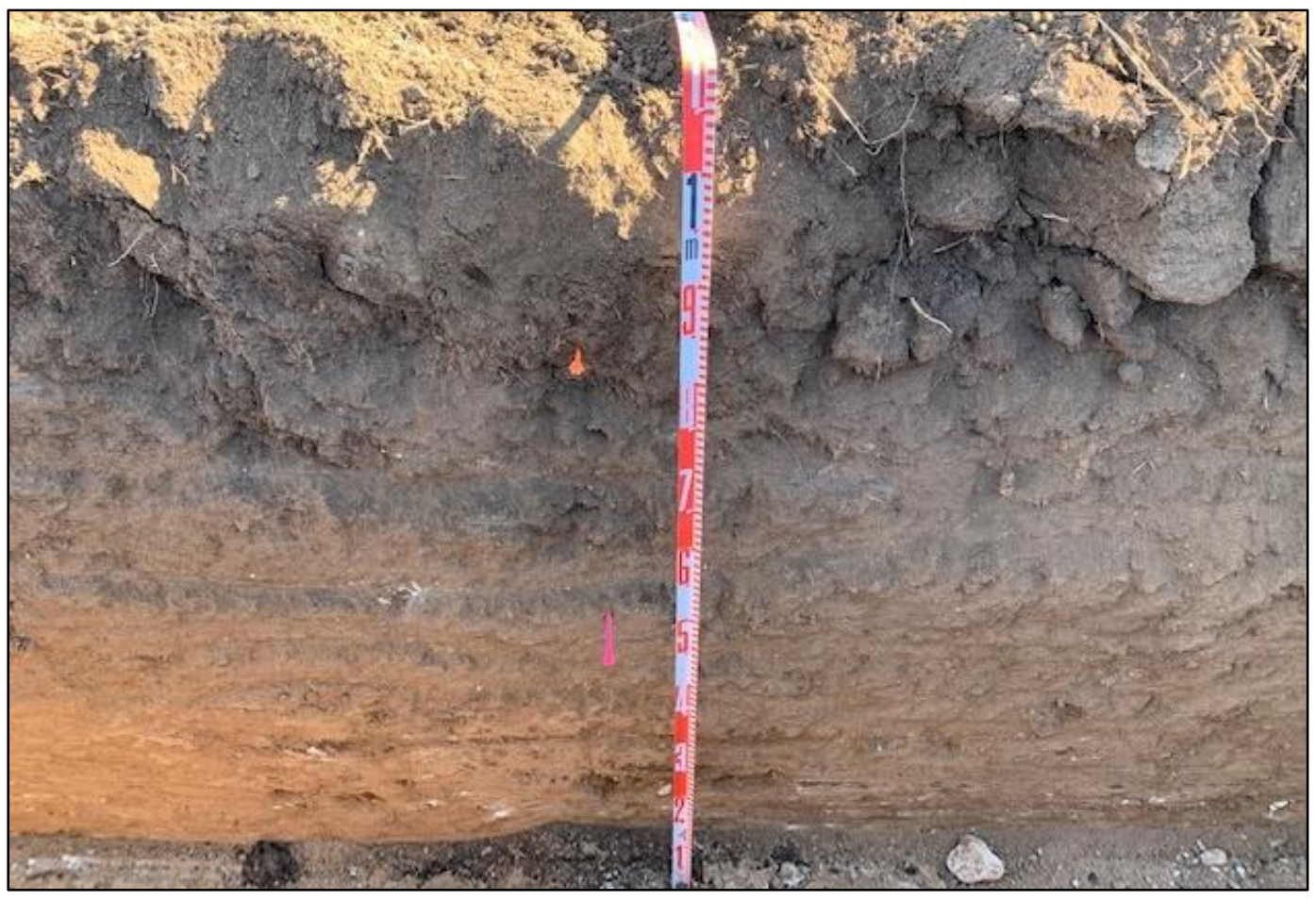

Figure B-2. Profile of BHT-1 (East Wall) 


\section{Table B-2. Backhoe Trench 2 (BHT-2)}

Trench No.:

$\mathrm{BHT}-2$

UTM Coordinates ${ }^{1}: \quad 0586992 \mathrm{E}, 3338786 \mathrm{~N}$

Comment:

BHT-2 was oriented north to south and measured 5.5 meters (18.0 feet) in length. It was excavated on a terrace in the southeastern portion of the West Interceptor segment of the project area just west of and parallel to Onion Creek to examine potential alluvial soils adjacent to the creek.

\begin{tabular}{c|c|l|l}
\hline \hline Zone & $\begin{array}{c}\text { Depth } \\
\text { (cmbs) }\end{array}$ & \multicolumn{1}{c|}{ Description } & Cultural Materials \\
\hline 1 & $0-33$ & $\begin{array}{l}\text { Dark grayish-brown clay loam; friable, somewhat plastic, } \\
\text { somewhat sticky consistency; granular subangular structure; } \\
\text { medium size; weak-moderate grade; rootlets (20\%); gradual } \\
\text { lower boundary }\end{array}$ & None \\
\hline 2 & $33-65$ & $\begin{array}{l}\text { Medium grayish-brown clay loam; somewhat sticky, somewhat } \\
\text { plastic, friable consistency; granular subangular structure; } \\
\text { medium size; moderate-grade, gradual lower boundary }\end{array}$ & None \\
\hline 3 & $65-128$ & $\begin{array}{l}\text { Light yellowish-grayish-brown clay loam; friable, somewhat } \\
\text { plastic, somewhat sticky consistency; granular subangular } \\
\text { structure; medium size; weak-moderate grade; gradual lower } \\
\text { boundary }\end{array}$ & None \\
\hline 4 & $128-300+$ & $\begin{array}{l}\text { Light yellowish-brown fine sandy loam; friable consistency; } \\
\text { moderate grade; granular subangular structure; medium size; } \\
\text { (80\%); large river cobbles at 300.0 cmbs (80\%) }\end{array}$ & None \\
\hline \hline
\end{tabular}

cmbs $=$ centimeters below surface 


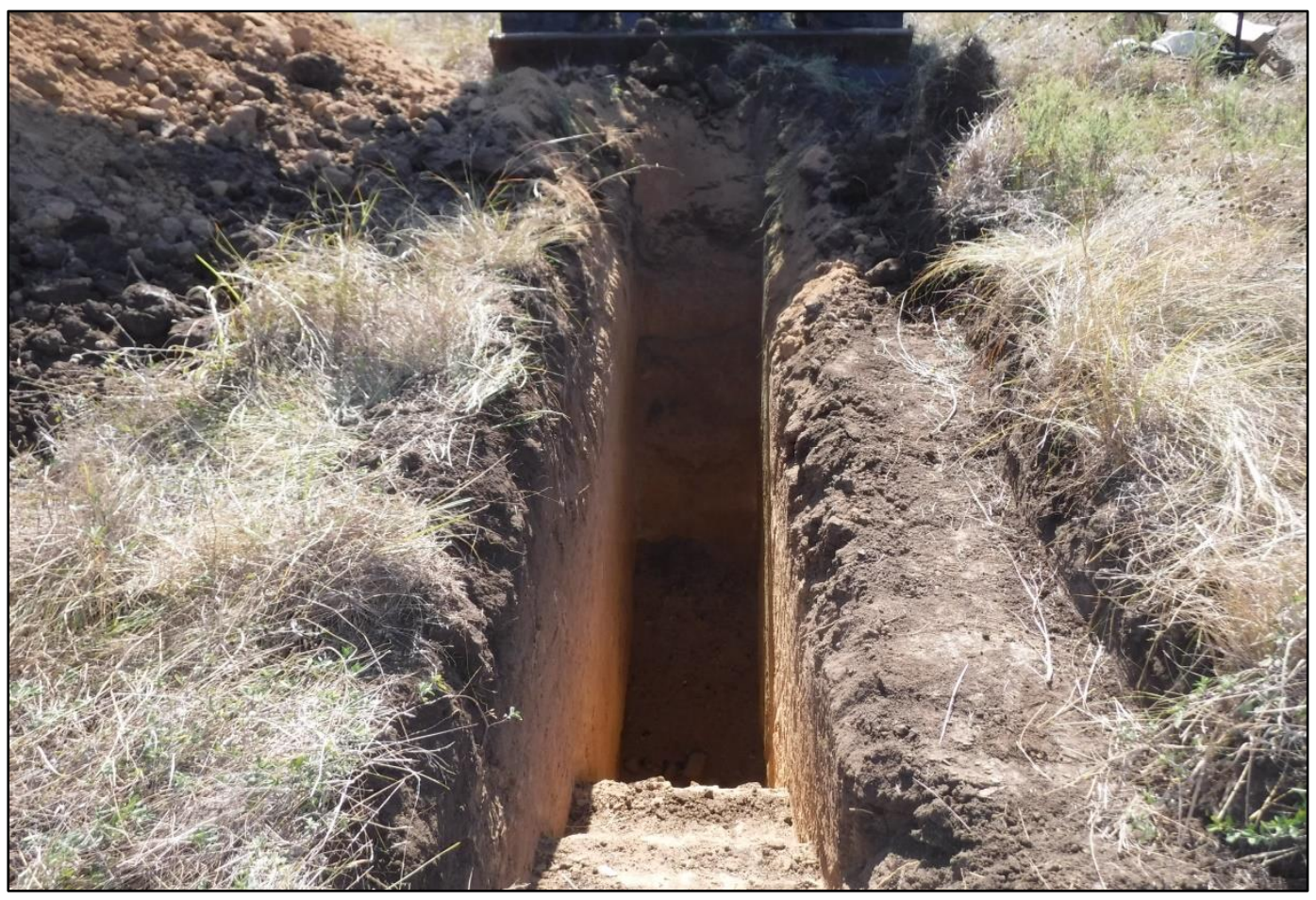

Figure B-3. Overview of BHT-2 (Facing South)

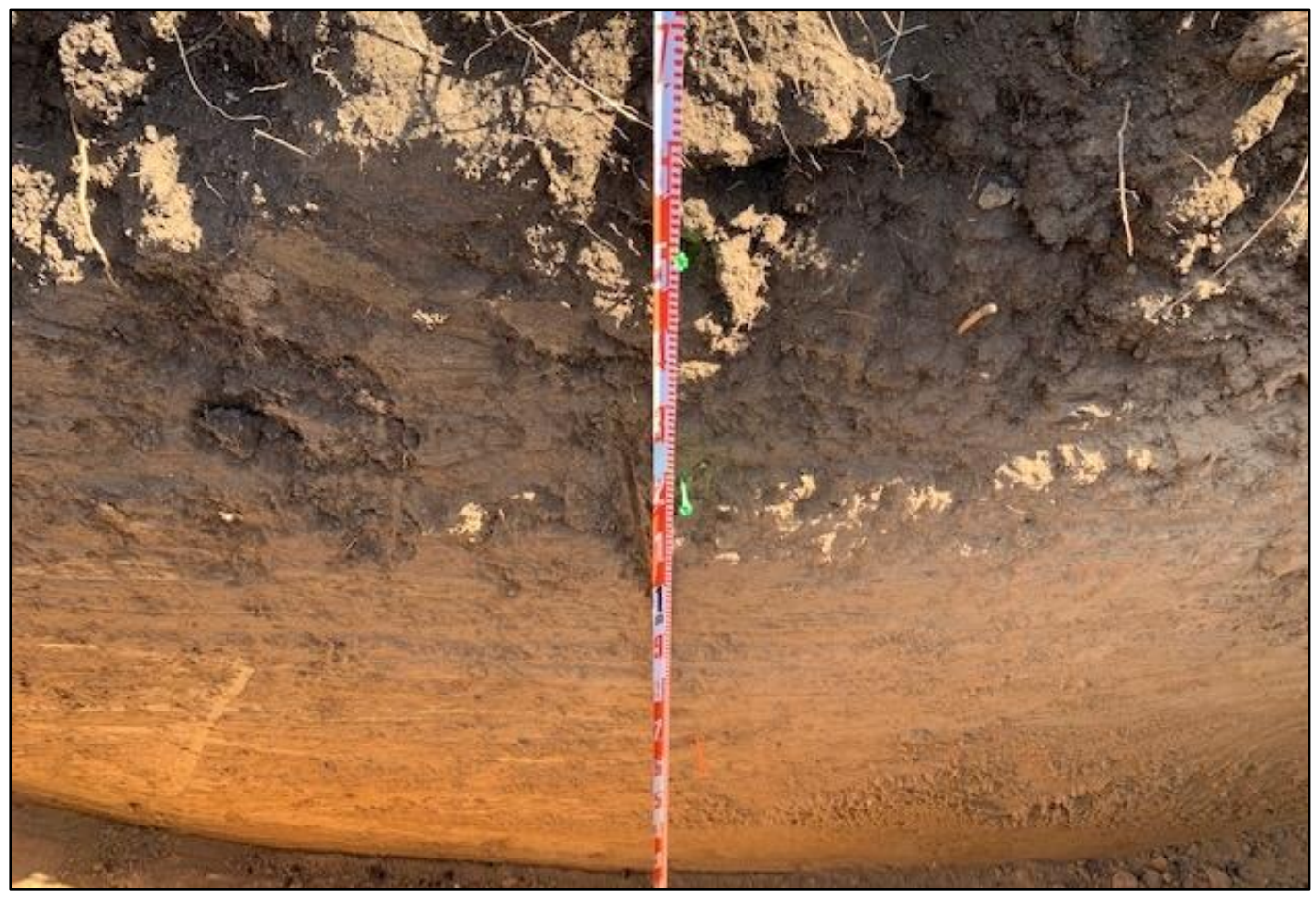

Figure B-4. Profile of BHT-2 (East Wall) 


\section{Table B-3. Backhoe Trench 3 (BHT-3)}

Trench No.

$\mathrm{BHT}-3$

UTM Coordinates ${ }^{1}: \quad 0587027 \mathrm{E}, 3338715 \mathrm{~N}$

Comment:

BHT-3 was oriented north to south and measured 5.5 meters (18.0 feet) in length. It was excavated on a terrace in the southeastern portion of the West Interceptor segment of the project area just west of and parallel to Onion Creek to examine potential alluvial soils adjacent to the creek.

\begin{tabular}{c|c|l|l}
\hline \hline Zone & $\begin{array}{c}\text { Depth } \\
\text { (cmbs) }\end{array}$ & \multicolumn{1}{c|}{ Description } & Cultural Materials \\
\hline \hline 1 & $0-30$ & $\begin{array}{l}\text { Pale grayish-brown fine clay loam; friable, somewhat plastic, } \\
\text { somewhat sticky consistency; firm; weak-moderate grade; } \\
\text { granular structure; rootlets (20\%); gradual lower boundary }\end{array}$ & None \\
\hline 2 & $30-95$ & $\begin{array}{l}\text { Medium grayish-brown fine clay loam; friable, somewhat } \\
\text { plastic, firm, somewhat sticky consistency; granular structure; } \\
\text { gradual lower boundary }\end{array}$ & None \\
\hline 3 & $95-160$ & $\begin{array}{l}\text { Light grayish-brown fine clay loam; friable, somewhat plastic, } \\
\text { somewhat sticky consistency; granular subangular structure; } \\
\text { weak-moderate grade; gradual lower boundary }\end{array}$ & None \\
\hline 4 & $160-350+$ & $\begin{array}{l}\text { Light yellowish-brown fine sandy loam; friable ,loose } \\
\text { consistency; moderate grade; granular structure; large river } \\
\text { cobbles at 350.0 cmbs (80\%) }\end{array}$ & None \\
\hline \hline
\end{tabular}

cmbs = centimeters below surface 


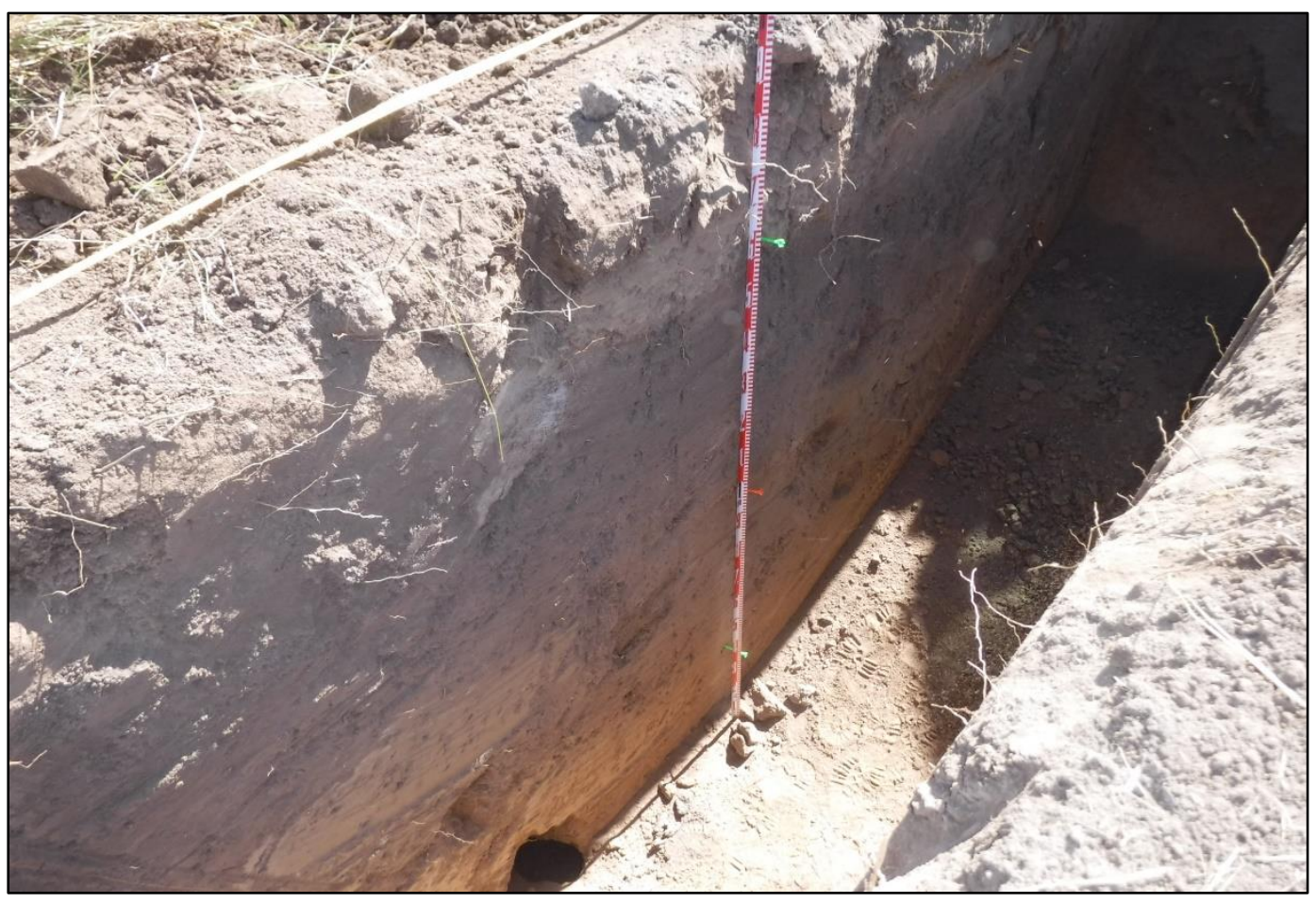

Figure B-5. Overview of BHT-3 (Facing Southeast)

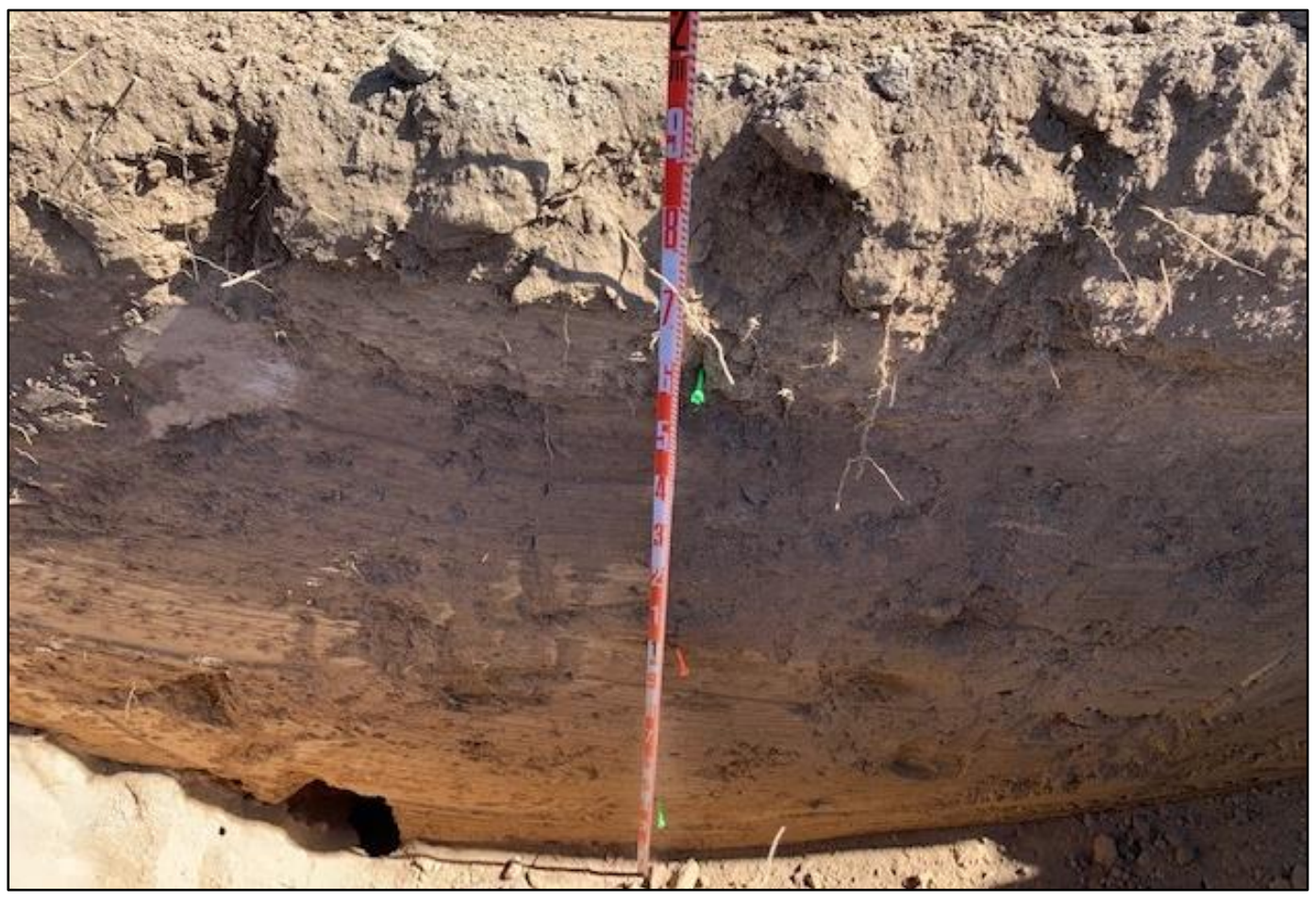

Figure B-6. Profile of BHT-3 (East Wall) 


\section{Table B-4. Backhoe Trench 4 (BHT-4)}

Trench No.:

$\mathrm{BHT}-4$

UTM Coordinates ${ }^{1}: \quad 0587060 \mathrm{E}, 3338652 \mathrm{~N}$

Comment:

BHT-4 was oriented north to south and measured 5.5 meters (18.0 feet) in length. It was excavated on a terrace in the southeastern portion of the West Interceptor segment of the project area just west of and parallel to Onion Creek to examine potential alluvial soils adjacent to the creek.

\begin{tabular}{c|c|l|l}
\hline \hline Zone & $\begin{array}{c}\text { Depth } \\
\text { (cmbs) }\end{array}$ & \multicolumn{1}{c}{ Description } & Cultural Materials \\
\hline \hline 1 & $0-35$ & $\begin{array}{l}\text { Medium grayish-brown fine clay loam; friable, somewhat } \\
\text { plastic, somewhat sticky consistency; granular structure; } \\
\text { moderate grade; rootlets (20\%); gradual lower boundary }\end{array}$ & None \\
\hline 2 & $35-135$ & $\begin{array}{l}\text { Light grayish-brown fine clay loam; friable, somewhat plastic, } \\
\text { somewhat sticky consistency; granular structure; weak- } \\
\text { moderate grade; few CaCO3 inclusions (20\%); gradual lower } \\
\text { boundary }\end{array}$ & None \\
\hline 3 & $135-350+$ & $\begin{array}{l}\text { Medium yellowish-brown fine sandy loam; loose consistency; } \\
\text { weak grade; granular structure }\end{array}$ & None \\
\hline \hline
\end{tabular}

$\mathrm{CaCO}_{3}=$ Calcium carbonate

cmbs $=$ centimeters below surface 


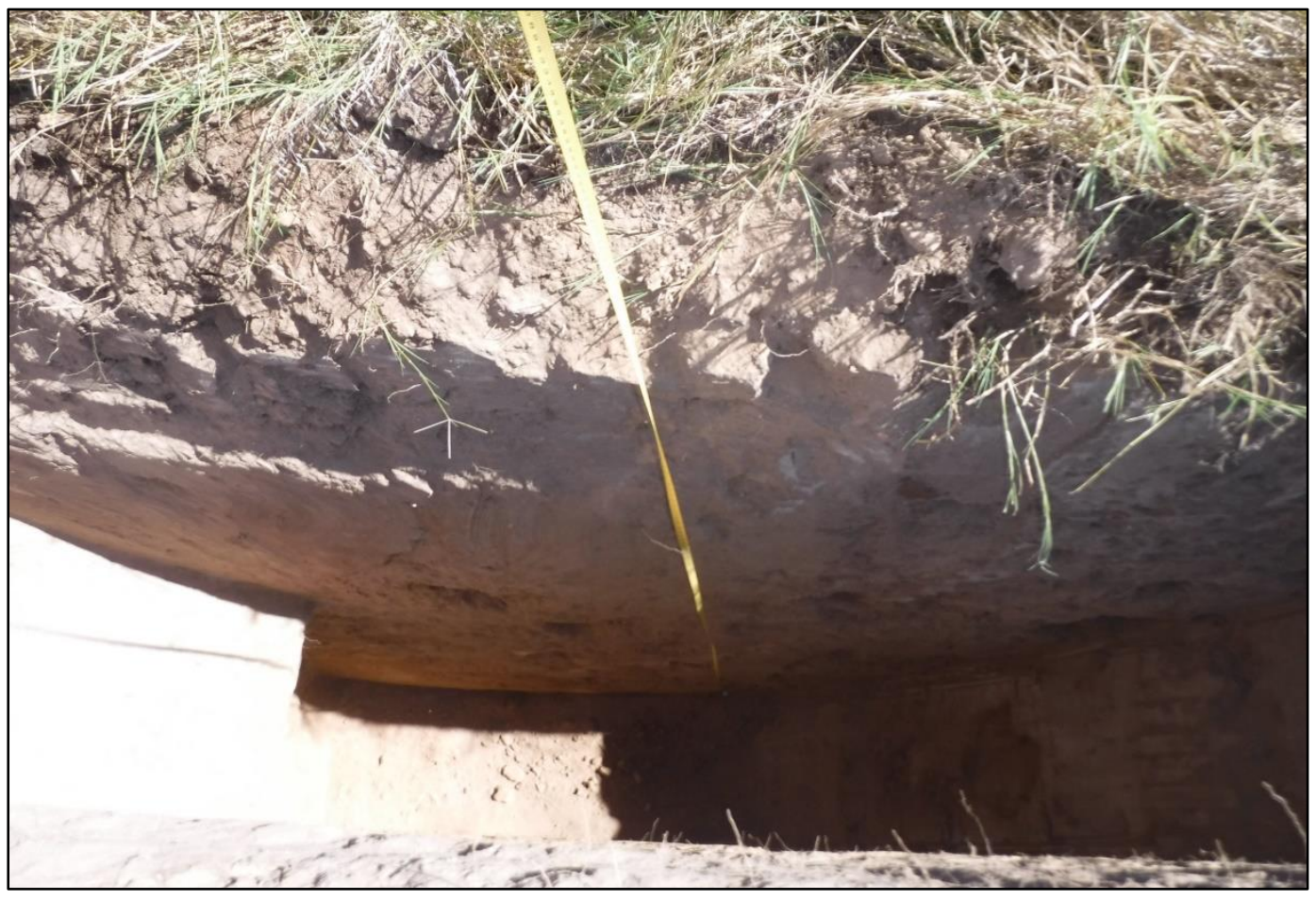

Figure B-7. Overview of Completed BHT-4 (Facing South)

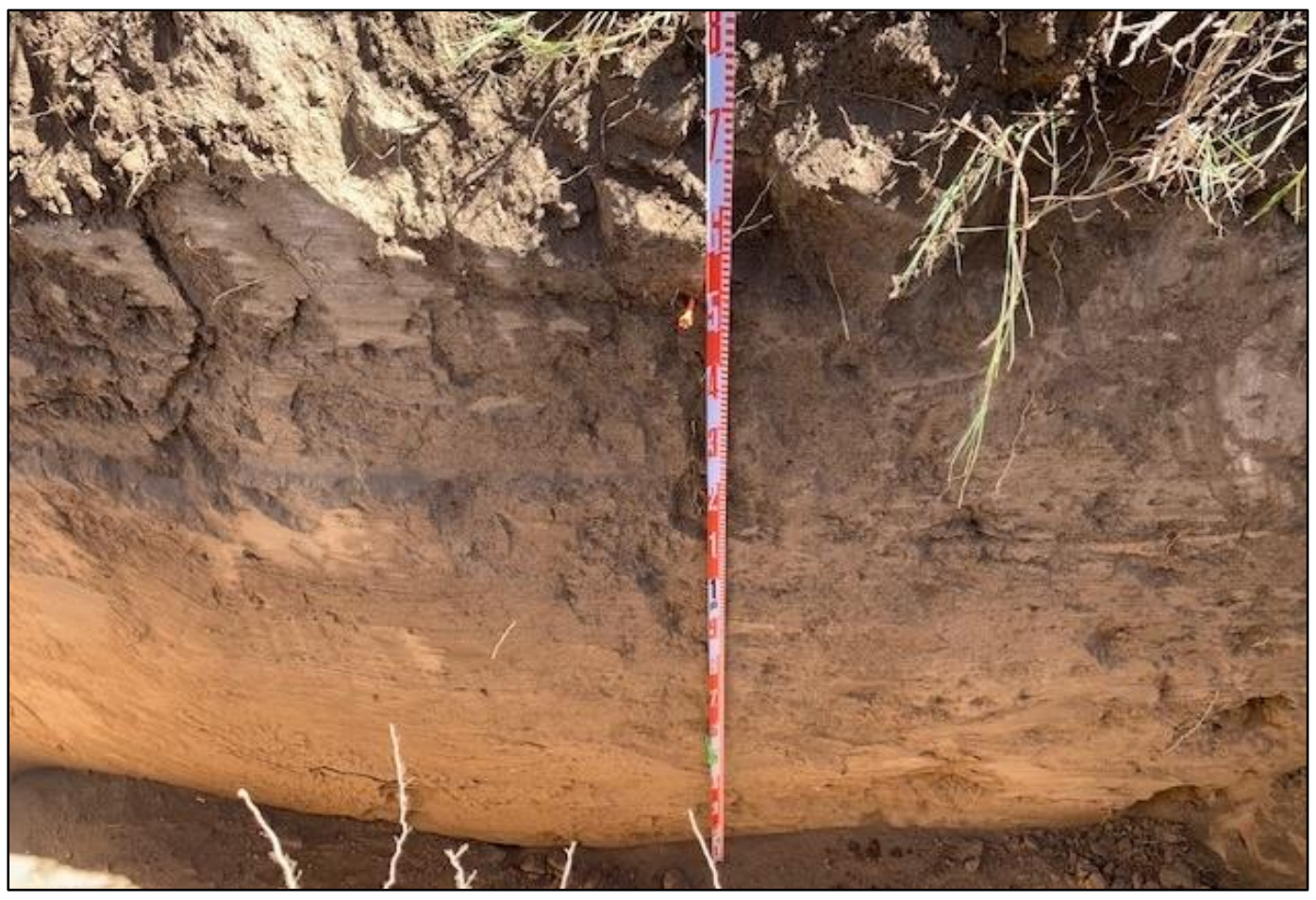

Figure B-8. Profile of BHT-4 (East Wall) 